\title{
WestVirginiaUniversity
}

THE RESEARCH REPOSITORY @ WVU

Graduate Theses, Dissertations, and Problem Reports

2003

\section{Metallothionein isoform 3 expression in human bladder urothelium}

Seongmi Park

West Virginia University

Follow this and additional works at: https://researchrepository.wvu.edu/etd

\section{Recommended Citation}

Park, Seongmi, "Metallothionein isoform 3 expression in human bladder urothelium" (2003). Graduate Theses, Dissertations, and Problem Reports. 1932.

https://researchrepository.wvu.edu/etd/1932

This Dissertation is protected by copyright and/or related rights. It has been brought to you by the The Research Repository @ WVU with permission from the rights-holder(s). You are free to use this Dissertation in any way that is permitted by the copyright and related rights legislation that applies to your use. For other uses you must obtain permission from the rights-holder(s) directly, unless additional rights are indicated by a Creative Commons license in the record and/ or on the work itself. This Dissertation has been accepted for inclusion in WVU Graduate Theses, Dissertations, and Problem Reports collection by an authorized administrator of The Research Repository @ WVU.

For more information, please contact researchrepository@mail.wvu.edu. 
Metallothionein isoform 3 expression in human bladder urothelium

\author{
Seongmi Park
}

Dissertation submitted to the Davis

College of Argiculture, Forestry and Consumer Sciences

at West Virginia University

in partial fulfillment of the requirements

for the degree of

Doctor of Philosophy

in

Genetics and Developmental Biology

Joginder Nath, Ph.D., Chair

Donald A. Sens, Ph.D

Mary A. Sens, MD., Ph.D

Daniel Pannaccione, Ph.D

Scott H. Garrett, Ph.D

Genetics and Developmental Biology Program

Morgantown, West Virginia

2003

Key words : Bladder Cancer, UROtsa, Metallothionein, Cadmium, Arsenic, In vitro transformation 


\section{ABSTRACT \\ Metallothionein Isoform 3 Expression in human Bladder Urothelium}

\section{Seongmi Park}

The third isoform of methallothionein, MT-3 is shown to have a restricted pattern of tissue distribution with expression confined to the neural tissue. Previous work done by this laboratory has been shown that MT-3 is not expression in the normal bladder but is over-expressed in bladder cacer with levels correlating to the type and grade of tumor. Recently, a new bladder epithelial cell line UROtsa has been characterized that does not express the MT-3 gene and may serve as a useful in vitro model system of the normal human urothelium. The goal of this study was to see the effect of MT-3 over expression in the normal human bladder epithelial cell line. The MT-3 transfected cells expressed the mRNA for the MT-3 gene but expressed very little MT-3 protein. Treatment with cadmium or zinc did not increased the level of MT-3 protein in MT-3 transfected clones. Otherwise MT-1E transfected UROtsa cells showed increased both mRNA and protein by exposure to cadmium. These data suggests that the MT-1/2 and MT-3 are regulated different ways. In vitro transformation model systems are very useful tools in the understanding of fundamental differences between normal cells and tumor cells if both have been derived from a common source. We showed the malignant transformation of normal human urothelial cell line by chronic exposure to cadmium or arsenic in vitro. The malignant transformation of these exposed cells was confirmed by increased growth rate, anchorage independent growth, and tumor development in nude mouse. The malignant transformation of normal human urothelial cells is compelling evidence that arsenic and cadmium have the potential to be human bladder. 


\section{ACKNOWLEDEMENTS}

The author thanks Dr. Joginder Nath for all support to be educated: Dr. Mary A. Sense, Dr. Scott H. Garrett, Dr. Seema Somji for all technical helps: Dr. Daniel Pannaccione for being a committee member. The author thanks especially to Dr. Donald A. Sens for giving me chance to work with him. 


\section{TABLES OF CONTENTS}

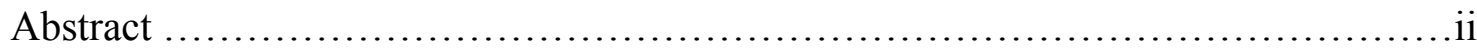

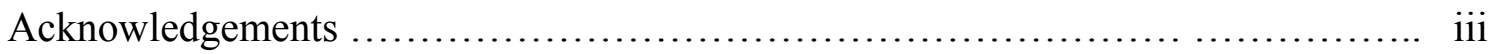

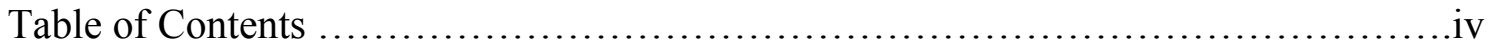

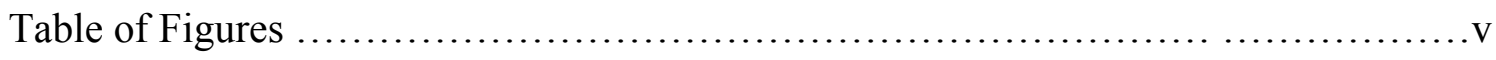

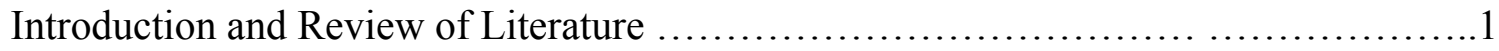

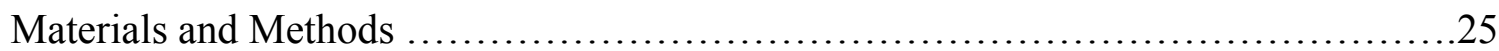

The Effect of Metallothionein Isoform 3 Expression in UROtsa Cell Line .............40

In vitro Transformation of UROtsa Cell Line by Chronic Exposure to Arsenic or

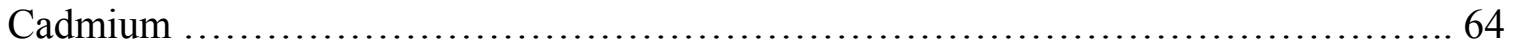

Tumorigenicity and Histological Observation of Tumors Produced by Arsenic- or

Cadmium-Transformed Cells in Nude Mouse ....................................... 90 


\section{TABLE OF FIGURES}

Figure 1. Stable overexpression of MT-3 mRNA in UROtsa cells

Figure 2. Expression of MT-3 in 16 MT-3 gene transfected UROtsa clones compared to other MT-3 gene transfected cell lines .45

Figure 3. Viability of UROtsa(3.1) and UROtsa(MT3) cells exposed to cadmium chloride

Figure 4. Expression of metallothionein isoforms in UROtsa(3.1) cells exposed to cadmium chloride

Figure 5. Expression of metallothionein isoforms in UROtsa(MT3) cells exposed to cadmium chloride

Figure 6. Expression of metallothionein-3 in UROtsa(MT3) cells exposed to cadmium Chloride

Figure 7. Expression of metallothionein-1/2 in UROtsa(3.1) (A) and UROtsa(MT3) (B) cells exposed to cadmium chloride

Figure 8. Viability of UROtsa(3.1) (A) and UROtsa(MT3) (B) cells exposed to zinc ...53

Figure 9. Expression of metallothionein-1/2 protein in UROtsa(3.1) (A) and UROtsa(MT3) (B) cells exposed to zinc 54

Figure 10. Expression of metallothionein-3 in UROtsa(3.1) (A) and UROtsa(MT3) (B) cells exposed to zinc 55

Figure 11. Stable overexpression of MT-1E mRNA in UROtsa cells .56

Figure 12. Viability of UROtsa(MT1E) cells exposed to cadmium chloride .57

Figure 13. Effect of cadmium on MT-1/2 protein expression in URO(MT1E) cells......58

Figure 14. Phase contrast photomicrographs of human urothelial cell line .68

Figure 15. The effect of cadmium or arsenic exposure to UROtsa cell growth 71

Figure 16. Effects of arsenic or cadmium exposure to UROtsa cell in colony formation assay 
Figure 17. Colony-formation capacity of UROtsa cells ......................... 75

Figure 18. Expression of metallothionein protein in UROtsa cells ..................77

Figure 19. Tumorigenicity of arsenic or cadmium exposed UROtsa cells in nude mice

Figure 20. Histological analysis of tumors produced by heterotransplatation of cadmiumtransformed UROtsa cells with serum into nude mice....................95

Figure 21. Histological analysis of tumors produced by heterotransplatation of cadmiumtransformed UROtsa cells without serum into nude mice 97

Figure 22. Histology (H\&E staining) of tumors produced by heterotransplantation of arsenic-transformed UROtsa cells with serum into nude mice .98

Figure 23. Histology of tumors produced by heterotransplantation of arsenic-transformed UROtsa cells without serum into nude mice 101

Figure 24. Histology of tumors produced by human prostate cells injected nude mice. .101

Table 1. Effect of exposure to arsenic or cadmium on doubling time of UROtsa cells ...72

Table 2. Tumorigenicity of arsenic or cadmium exposed UROtsa cells in nude mice...94 
INTRODUCTION AND REVIEW OF LITERATURE 


\section{METALLOTHIONEIN}

Metallothionein (MT) was discovered in 1957 as a cadmium-binding protein from equine kidney cortex (1). The metallothioneins are present in a broad range of organisms from a few prokaryotes to all eukaryotic species from yeasts, flies, plants and vertebrates. The definition of metallothioneins is cysteine rich low molecular weight ( 6 to $7 \mathrm{kDa}$ ) nonenzymatic metalloproteins or metallopeptides with a high affinity for heavy metals (2). The metallothioneins are divided into three classes based on structural criteria. Class I metallothioneins are metalloproteins with the cysteine residues arranged as Cys-X-Cys and their nucleotide sequences are highly conserved. Class I includes all MTs found in vertebrates including mammals and some invertebrates such as crustaceans and mollusks. Class II metalloproteins are found in unicellular eukaryotes such as yeasts, and their primary structure has no CysX-Cys structures like class I. Class III, present in plants, is a nontranslationally synthesized metal thiolate polypeptide and known as phytochelatin with atypical gamma-glutamylcysteinly units.

Based on small differences in sequence and charge characteristics, mammalian MTs can be divided into four groups from MT-1 to MT-4. The structures of all four isoforms are highly conserved at the amino acid sequence level and are consisted of three exons and two introns. The mammalian MTs are 61-68 amino acid peptides containing 20 cysteines, 6-8 lysines, 7-10 serines, and a single acetylated methionine at the amino terminus (3). The most unique characteristic of MT is the recurrence of Cys-X-Cys tripeptide sequences where $\mathrm{X}$ is for any amino acid residue except 
cysteine and aromatic amino acids. The sulfur atoms of 9 cysteines from N- terminal beta domain and 11 cysteines from C-terminal alpha domain provide cooperative binding sites for various transitional metals including zinc and cadmium (2). Therefore, each MT protein binds 7-10 $\mathrm{g}$ atoms of metal $/ \mathrm{mol} \mathrm{MT}$, up to three metals in alpha domain and four metals in beta domain. Because metals stabilize the secondary structure of protein, loss of metal causes structural changes. It makes them susceptible to proteolysis.

In the mouse, there are four MT genes that reside in a 50-kb region on chromosome 8 without any pseudogenes. In contrast, the human MT genes are more complicated. The human MT-1 and MT-2 genes are encoded by a multigene family that likely doubled as a result of a gene duplication event that occurred between the time of divergence of rodents and humans. The human MT genes are clustered at a single locus on chromosome 16(16q13) and consist of 10 functional isoform (MT-1A, MT-1B, MT-1E, MT-1F, MT-1G, MT-IH, MT-X, MT-2A, MT-3 and MT-4) and 7 nonfunctional isoforms( MT-1C, MT-1D, MT-1I, MT-1J, MT-1K, and MT2-B) (4-6). The existence of multiple MT-1 and MT-2 isoform genes raises the possibility that isoforms may have different roles and be regulated differently in humans. For example, metals induce all MT-1 and MT-2 isoforms whereas glucocorticoids only induce MT-2A and MT-1E in human (7). Whether there are distinct functions for each of the human MT isoforms or whether they merely represent a duplication of function has not yet been established.

The common MT isoforms, MT-1 and MT-2, differ by only one single negative 
charge and have been studied extensively. They consist of 61-62 amino acids and exhibit a ubiquitous pattern of tissue distribution, show high levels in the liver and kidney, and are highly inducible by various stimuli including metals, hormones, cytokines and physical and chemical stresses (8). When cells are exposed to heavy metals such as cadmium, the amount of MT-1 and MT-2 proteins are elevated from several to hundreds times higher due to increased rates of transcription. The dramatic inducibility of metallothioneins by heavy metals makes promoters of MT-1 and MT-2 genes excellent candidates to be used to control expression of a fusion gene via an exogenous metal supply (9). The MT-3 and MT-4 isoforms were only recently discovered and are subjects of more limited studies. MT-4, the most recently identified isoform, with 62 amino acids, is present in the stratified squamous epithelium of skin, tongue, and intestinal lining and may be involved in the differentiation of these tissues (10). MT-3, a brain-specific MT isoform, was isolated from the normal human brain extract but was deficient in brains of patients with Alzheimer $(11,12)$. Decreased MT-3 protein in Alzheimer's patients suggested that MT-3 may suppress brain neurotropic activity. MT-3 is predominantly expressed in neurons of the central nerve system, although recently published papers demonstrate that it is also detected in reproductive organ tissues, tongue, stomach, heart and kidney $(13,14)$. The human MT-3 contains 68 amino acids and shows around $64 \%$ identity with human MT-1 and MT-2. The growth inhibitory activity of the MT-3 is abolished by a double mutation within the beta domain resulting in the conversion of the C-P-C-P sequence to either C-S-C-A or C-T-C-T. This proline-rich region in the 
N-terminal beta domain of MT-3 may have growth inhibitory activity that other metallothionein isoforms do not have (15). When transfected into baby hamster kidney cells, MT-3 gene but not MT-1 gene showed inhibition of cellular proliferation under conditions of zinc deficiency. The discovery of growth inhibitory activity of MT-3 was the first indication that different MT isoforms may have different functions. MT-3 knockout mice show reduced zinc content in brain and are more sensitive to seizure-induced injury, whereas mice overexpressing MT-3 are resistant to this damage and kainic acid toxicity (16).

The biosynthesis of metallothionein is controlled by complex processes. Studies of MT gene structure and regulation have been focused on mouse MT genes because of their simplicity. Several studies demonstrate that MT genes are inactive in some cells as a consequence of DNA methylation (17). In cells or plants selected for resistance to cadmium, enhanced expression of MT protein can also be achieved through amplified copies of MT gene $(18,19)$. The MT genes in most cells are mainly controlled at the transcriptional level by various inducers (20). In general, MT genes have several cis-acting response elements, including metal response elements (MREs), a TPA-responsive element, a cyclic AMP responsive element, and an interferon responsive element. Two proteins were identified from nuclear extracts of HeLa cells as trans-acting elements for metal-mediated MT gene transcription. The MRE-binding protein (MREBP) binds MREs of the human MT-2A for inhibiting MT gene transcription. The MRE-binding transcription factor (MTF-1) is a constitutively active zinc-sensitive transcription factor. MTF-1 may bind to multiple copies of metal 
response elements (MREs) in the promoter region of an MT gene and elevate MT gene transcription rates (21). However, MT-3 and MT-4 are less or not responsive to inducers and have a more restricted pattern of expression. The MT protein level is also regulated by protein degradation. Several studies showed that half-life of MT protein also depends on the age of the animals and the type of metal bound to MT (22). The degradation of MT occurs in both cytoplasm and lysosomes. A in vitro study demonstrated that low $\mathrm{pH}$ increased the rate of metal release from MT. For example, zinc is fully released from $\mathrm{MT}$ at $\mathrm{pH} 4$. The lysosomes are acidic with a $\mathrm{pH}$ range of between 3.6 and 5, resulting in zinc dissociation from MT. Several proteases including serine protease and trypsin digest MT partially in vitro. Some proteases including acidic proteases and cathepsin B are involved with MT degradation in lysosomes (23). The degradation rate of MT increases when MT binds less than five atoms of metal (24). The degradation of MT protein is primarily regulated by cellular zinc content, and apo-MT is more susceptible to degradation than metal-occupied MT (25).

Even though amino acid sequences of MT proteins are highly conserved and expressed from prokaryotic to eukaryotic organisms, biological functions of the MTs are still controversial (26). The large number of factors that stimulate the biosynthesis of MT makes it difficult to pinpoint a specific biological role. The understanding of the functions of MTs has been focused on their roles in heavy metal detoxification because of their metal binding ability. Numerous in vivo and in vitro studies have confirmed the protective function of MTs against heavy metal toxicity (27). The MTnull 
mice showed an increased sensitivity to cadmium-induced renal injury and hepatotoxicity after chronical exposure to cadmium (28). In contrast, transgenic mice that carry 56 copies of the MT-1 gene showed resistance against cadmium lethality and hepatotoxicity (29).

The MTs also are considered as cellular storage sites for homeostasis of essential metals such as zinc and copper during growth and development. Although MTs are well known for their protection against cadmium, yet when they were isolated from liver tissue, MTs were predominantly zinc-containing proteins (30). These results demonstrated that MT binds to zinc and copper under physiological conditions therefore it might be involved in the metabolism of nutrient metals. Zinc is an essential participant in many DNA and RNA polymerases and serves as a structural component of the zinc finger domains in over 300 DNA-binding proteins (8). Therefore, MT may control function of zinc-dependent proteins by acting as both zinc donor and an acceptor. MTs may function as potent scavengers of free radicals because of their high cysteine content. The role of MTs as antioxidants was suggested in MT-1 and MT-2 knock out cell studies. It was shown by Lazo and coworkers that MT null cells were more sensitive to tert-butyl hydroperoxide-induced oxidative stresses (31).

The experiment with MT-1/2 double knockout mice was disappointing because these MT-null mice were normal under the standard laboratory condition except for their higher susceptibility to heavy metal toxicity and UV-irradiation, and higher sensitivity to changes in dietary zinc content during development, indicating that MT 
is not essential for life. The MTs are also not essential for protection from oxidative stress except under extreme conditions. Glutathione and other gamma-glutamyl compounds are the major cellular non-protein thiol-containing reductants that protect cells against oxidative stress and detoxification of xenobiotics and may represent an integral part of the toxic response of some heavy metals (32). The glutathione appears to be the first line of defense against cadmium toxicity preceding MT induction. Although glutathione and MT show similar detoxification and anti-oxidation functions in vivo, mice can survive without MT but not without glutathione. If the function of MTs is limited to protection from cellular toxicity, it would be expressed to be expressed only after exposure to toxic heavy metals and other environmental stresses but in fact the basal level of MT proteins is relatively high. MTs are also induced not only by a variety of metals but also several hormones, cytokines, growth factors, and tumor promoters, implying their involvement in diverse cellular processes (33). Due to overexpression of MT protein in proliferating cells, various tumors, and developing tissues, it has been suggested that MT takes part in the control of cellular proliferation and differentiation. The involvement of MT with zinc metabolism, the requirement of zinc during G1 to S phase and transient translocation of MT protein from cytoplasm into nucleus during cell proliferations lead to possible link between MT and cancer (34). The levels of MT expression have been investigated in a wide variety of tumors. Although MTs appear in various human tumors, the expression of MT is not universal to all tumors. The presence of MT may depend on the type of tumor, the cellular origin, the morphological 
heterogeneity, or the stage of growth (35). The MTs could be found at high levels in the nucleus and in the cytoplasm in both benign and malignant tumors. It has been shown that the incidence of apoptosis decreases with increasing immunoreactivity of MT staining (36). However, in some tumor types such as colonic carcinoma, a correlation between MT overexpression and better prognosis has been found (37). Otherwise MT-1 and MT-2 overexpression appears to be associated predominantly with more malignant, higher - grade tumors in ductal breast cancer (38), prostate cancer (39), skin carcinoma, melanomas (40), cervical cancer (41), acute lymphoblastic leukemia (42), and pancreatic carcinomas (43). Several studies demonstrated that MT-1 and MT-2 also are overexpressed in bladder cancer (44). The intensity of MT-1 and MT-2 staining is correlated with bladder tumor grade, with the highest-grade tumors having the more intense MT protein.

The resistance of certain tumors to anticancer drugs is one of the major problems in cancer chemotherapy. Various defense mechanisms against anticancer drugs by cancer cells include increased expression of multidrug resistance gene, decreased drug accumulation or increased DNA repair activity. Another suggested mechanism is the protection of targeted macromolecules by increased cellular thiols such as glutathione or MT. MT was considered as one of the anticancer drug-resistance molecules because of high cysteine content and alkylating agent binding ability and induced MT synthesis by alkylating agents (45). The acquisition of drug resistance has been recognized after exposure to anticancer drugs. The increased expression of MT 
in certain tumors is associated with resistance to chemotherapeutic agents. Many clinically used anticancer agents are electrophilic, and generate DNA inter- and intrastrand cross-links. Cisplatin-based chemotherapy has been widely used to treat patients with metastatic and locally advanced carcinoma of the bladder for more than two decades (46). Cisplatin is one of the most potent cytotoxic drugs in chemotherapy and ameliorates numerous tumors. Cistplatin also is a common chemotherapeutic agent for solid tumors, including testicular carcinomas, ovarian cancer, cancer of the head and neck and small cell lung carcinomas (47). Cisplatin causes intrastrand DNA crosslinking, thereby disrupting DNA and RNA synthesis (48). Nevertheless, resistance to cisplatin is a problem that is encountered in the chemotherapy of urologic tumors, especially transitional cell carcinomas. The overexpression of MT in bladder tumors was found in several studies that had failed cisplatin chemotherapy $(49,50)$.

The immunohistochemical staining demonstrates that overexpresssion of the MT1 and MT-2 protein is correlated with cisplatin resistance in transitional cell carcinoma of the urinary tract (51). The cells with acquired resistance to heavy metals overexpress MT and are cross resistant to the alkylating agents. The suggested mechanism of cisplatin resistance by MT is that a nucleophilic protein, MT, interacts with electrophilic anticancer drugs such as cisplatimum and cyclophosphamide. MT binds to cisplatin in the cytoplasm and this complex decreases the intranuclear drug concentration, thus preventing cisplatin from forming DNA intrastrand adducts (52). There also is considerable evidence that some cisplatin-resistant cell lines do not 
show increased MT levels (53). Therefore, MTs may play an important role in decreased cisplatin toxicity but not critical.

The finding of altered metallothionein expression in bladder cancer is particularly significant because bladder cancer has a strong association with the environment pollution. Epidemiological studies dating back to the 19th century showed that bladder cancer was one of the first cancers recognized as being caused by carcinogens present in the industrial setting and factory workers (54).

\section{BLADDER CANCER}

Bladder cancer is the fourth common cancer among men and eighth among women (55). In the United States, approximately 54,000 new cases of bladder cancer and around 12,000 bladder cancer related deaths are reported each year (56).

Although which chemical in smoke is responsible for carcinogenesis is uncertain, a major factor in the causation of bladder cancer is tobacco usage, with $40-85 \%$ of all bladder cancer cases attributable to smoking cigarettes. Moreover, smokers have a 2 to 10 -fold increased risk over nonsmokers for developing bladder tumors (57). A strong association between cigarette smoking and bladder cancer has also been defined (58). Smoking is estimated to cause two to fourfold increased risk for bladder cancer, and estimates maintain that $50 \%$ of bladder cancers would not occur in the absence of cigarette smoking, with the majority of the remaining bladder cancers being caused by industrial or agricultural carcinogens.

The mammalian urinary bladder, a dynamic reservoir for urine, expands and contracts depending on the volume contained within. The mammalian bladder wall is 
composed of serous layer, muscular wall and transitional epithelium. The transitional epithelium, urothelium, exhibits unique structural characteristics associated with its specialized role as a permeability barrier and accommodating tissue structure. The urothelia are subdivided into basal cells, intermediate cells and squamous cells.

Clinical bladder cancers are heterogeneous in their growth behavior and histopathological subtypes, which include transitional cell carcinoma (TCC), squamous cell carcinoma, and adenocarcinoma. TCC, which makes up $90 \%$ of all bladder cancer cases, is associated with cigarette smoking and occupational and environmental chemical exposures. Squamous cell carcinomas are observed in 5$10 \%$ of all bladder cancer cases and are associated with chronic irritation of the bladder mucosa. Adenocarcinoma is seen around 1-2 \% of bladder cancer cases. The definition of tumor stage and grade is how far the tumor has progressed. The higher the grade or stage means the worse the cancer. Upon microscopic examination bladder cancers are divided into the superficial bladder cancer and invasive bladder cancer based on metastasis. The most common TCC is superficial bladder tumor as a low grade papillary tumor with relatively benign behavior but high recurrence rate. Superficial transitional cell carcinoma bladder tumors do not invade lamina propria, a thin membrane that separates the mucosa of the bladder from the muscle layer. The muscle invasive carcinoma in situ (CIS) is frequently metastasized and marked as high grade. Around $10 \%$ of patients with benign tumor eventually develop malignant disease (59). Over the last 15 years, the annual incidence of bladder cancer has increased by nearly a third. The incidence of bladder cancer is increasing, and despite 
advances in chemotherapy, survival rates for invasive bladders have not significantly improved.

The development of human bladder cancer is a long complex process including activation and inactivation of cellular genes. Studies with karyotypic analyses in human bladder cancer tissues and cells showed partial deletion of several chromosomes and mutations. The cytogenetic and allelic deletion analyses of clinical samples of human bladder cancers indicate that loss of genes on chromosomes $3 \mathrm{p}, 6 \mathrm{q}$, $8 \mathrm{p}, 9 \mathrm{q}, 11 \mathrm{p}, 13 \mathrm{q}, 17 \mathrm{p}$, and $18 \mathrm{q}$ may contribute to tumorigenic transformation of human urothelial cells $(13,60)$.

\section{CARCINOGENECITY OF ARSENIC AND CADMIUM}

Arsenic is a common environmental chemical. In biological systems, inorganic arsenic exists as either arsenate (As5+) or arsenite (As3+). Arsenic in drinking water is predominantly inorganic and highly toxic. Inorganic arsenic is detoxified through methylation and then methylated arsenicals are eliminated via the urine (61). The primary concern for chronic exposure of human populations to arsenic by inhalation exposure and contaminated drinking water is its carcinogenic potential. Although animal studies do not provide any evidence of carcinogenesis of arsenic, there is considerable evidence that arsenic causes cancer in humans. Arsenic is a human carcinogen and a leading top priority hazard in the United States (62). Although arsenic is associated with various tumors, including lung, skin, bladder and liver, the mechanism of arsenic carcinogenesis is still unclear (63). Cadmium is a common environmental toxic material. Acute exposure to cadmium produces hepatic, 
pulmonary, and testicular injury, whereas chronic exposure results in renal and bone injury and cancer, as well as toxicity to other organs. Even though cadmium is officially classified as a carcinogen by International Agency for research on Cancer (IARC) based on animal studies, the molecular mechanism of cadmium-induced carcinogenesis remains controversial (64). Recent reports have demonstrated the malignant transformation of immortalized cell lines by continuous exposure to heavy metals $(65,66)$. These trials are useful for better understanding of heavy metalinduced transformational mechanisms.

\section{OBJECTIVES OF THIS STUDY}

This laboratory's interest in MT-3 originated from recent observations that MT-3 was overexpressed in all human bladder cancers, but was not expressed in normal urothelial cells (67). The level of MT-3 expression correlated to the grade of the bladder cancer and was elevated in dysplastic lesions. These features suggested that MT-3 might be developed as a biomarker for human bladder cancer. Recently, a new cell culture model of human urothelium was developed by this laboratory through altering the growth medium formulation of the previously isolated UROtsa cell line from a serum-containing to a serum-free medium $(68,69)$. UROtsa cells maintained in serum-free medium have several morphological features of transitional epithelium of the urinary bladder including a multilayered appearance and apical location of umbrella-like cells which exhibit tight junctions. These cells also have a basal expression pattern of MT similar to that observed in in situ urothelium. The UROtsa cell line does not express the MT-3 gene and may serve as a useful in vitro system for 
the normal human urothelium for this study.

The first aim of these studies was to determine if there is a functional consequence of forcing MT-3 overexpression onto the MT-3 null background known to exist in the normal urothelial cell. In chapter three, the UROtsa cell line was stably transfected with MT-3 cDNA under control of the cytomegalovirus (CMV) promoter and the effect of MT-3 overexpression in the UROtsa cell line was demonstrated. Heavy metal exposure was chosen for induction of MT gene expression and two metals having diverse exposure patterns in human were studied: cadmium, an environmental pollutant, and zinc, a nontoxic essential trace element.

The second goal of the study was to determine transformational ability of cadmium or arsenic on the UROtsa cell line. Recently the carcinogenic effect of cadmium and arsenic was reported, but the molecular mechanism of carcinogenesis is not clear $(70,71)$. In chapter four, UROtsa cells were cultured with cadmium or arsenic for up to 10 months. The possibility of transformation of these UROtsa cells was tested by measurements of growth rate, a soft agar assay, and tumor formation after injection into nude mice. The protein samples also were collected during this period and MT protein levels were measured.

The final goal of these studies was to assess the role of MT in cadmium or arsenic induced carcinogenesis. Even though MT was overexpressed in several human tumors, the functional role of MT in protection of tumor cell growth is poorly understood. In chapter five, histological observations of nude mice that were injected by transformed UROtsa cells were performed. The expression of MT was also tested 
by immunohistochemistry.

\section{REFERENCES}

1. Margoshes M., Vallee B.L. (1957) A cadmium protein from equine kidney cortex. J. Am. Chem. Soc. 79:4813

2. Binz P.A. (1996) Metallothionein : studies on molecular evolution and on the structural and chiroptical features of their metal thiolate clusters. Ph.D thesis.

3. Ebadi M., Iversen P.L., Hao R., Cerutis D.R., Rojas P., Happer H.K., Murrin L.C., Pfeiffer R.F. (1995) Expression and regulation of brain metallothionein. Neurochem. Int. 27:1-22

4. Stennard F.A., Holloway A.F., Hamilton J., West A.K. (1994) Characterisation of six additional human metallothionein genes. Biochim. Biophy. Acta 1218:357365

5. Karin M., Richards R.I. (1982) Human metallothionein genes - primary structure of the metallothionein-II gene and a related processed gene. Nature 299:797-802

6. West A.K., Stallings R., Hildebrand C.E., Chiu R., Karin M., Richards R. (1990) Human metallothionein genes:structure of the functional locus at 16q13. Genomics 8:513-518

7. Schmidt C.J., Hamer D.H. (1986) Cell specificity and an effect of ras on human metallothionein gene expression. PNAS 83:3346-3350

8. Vallee B.L., Falchuk K.H. (1993) The biochemical basis of zinc physiology. Physiol.Rev. 73:79-118

9. Palmiter R.D., Brinster R.L., Hammer R.E., Trumbauer M.E., Rosenfeld M.G., 
Brinberg N.C., Evans R.M. (1982) Dramatic growth of mice that develop from eggs microinjected with metallothionein-growth hormone fusion genes. Nature 300:611-615

10. Quaifer C.J., Finldey S.D., Whitemore J.C., Froelic G.J., Kelly E.J., Zambrowicz B.P., Palmiter R.D. (1994) Induction of a new metallothionein isoform (MT-1V) occurs during differentiation of stratified squamous epithelia. Biochemistry $33: 7250-7259$

11. Uchida Y., Takio K., Titani K., Ihara Y., Tomonaga M. (1991) The growth inhibitory factor that is deficient in the Alzheimer's disease brain is a 68 amino acid metallothionein-like protein. Neuron 7:337-347

12. Tusji S., Kobayashi H., Uchida Y., Ihara Y., Miyatake T. (1992) Molecular cloning if human growth inhibitory factor cDNA and its down-regulation in Alzheimer's disease. EMBO J. 11:4843-4850

13. Moffatt P., Seguin C. (1998) Expression of the gene encoding metallothionein-3 in organs of the reproductive system. DNA and Cell Biol. 17:501-510

14. Garrett S.H., Sens M.A., Todd J.H., Somji S., Sens D.A. (1999) Expression of MT-3 protein in the human kidney. Toxicol. Lett. 105:207-214

15. Uchida Y., Ihara Y. (1995) The N-terminal portion of growth inhibitory factor is sufficient for biological activity. J. Biol. Chem. 270:3365-3369

16. Palmiter R.D. (1995) Constitutive expression of metallothionein-III (MT-III), but not MT-I, inhibits growth when cells become zinc deficient. Toxicol. Appl. Pharmacol. 135:139-146 
17. Jahroudi N., Foster R., Price-Haughey J., Beitel G., Gedamu L. (1990) Cell-type specific and differential regulation of the human metallothionein genes. J.Biol. Chem. 265:6506-6511

18. Andrews G.K. (1990) Regulation of metallothionein gene expression. Prog. Food. Nutri. Sci. 14:193-238

19. Beach L.R., Palmiter R.D. (1981) Amplification of the metallothionein-I gene in cadmium-resistant mouse cells. PNAS 78:2110-2114

20. Ghoshal K., Jacob S.T. (2001) Regulation of metallothionein gene expression. Prog. Nucleic Acid Res. Mol. Biol. 66: 357-384

21. Brugnera E., Georgiev O., Radtke F., Heuchel R., Baker E., Sutherland G.R., Schaffner W. (1994) Cloning, chromosomal mapping and characterization of the human metal-regulatory transcription factor MTF-1. Nucleic Acids Res. 22:31673173

22. Monia B.P., Buff T.R., Ecker D.J., Mirabelli C.K., Crooke S.T. (1986) Metallothionein turnover in mammalian cells. J. Biol.Chem. 261:10957-10959

23. Moffatt P., Denizeau F. (1997) Metallothionein in physiological and physiopathological processes. Drug Meta. Rev. 29:261-307

24. Choudhuri S., McKim J.M. Jr., Klassen C.D. (1992) Role of hepatic lysosomes in the degradation of metallothionein. Toxicol. Appl. Pharmacol. 115:64-71

25. Feldman S.L., Failla M.L., Cousuns R.J. (1978) Degradation of rat liver metallothioneins in vitro. Biochim. Biophy. Acta 544:638-646

26. Klassen C.D., Liu J., Choudhuri S. (1999) Metallothionein: an intracellular 
protein to protect against cadmium toxicity. Annu. Rev. Pharmacol. Toxicol. $39: 267-294$

27. O’Flaherty E.J. (1998) Physiologically based models of metal kinetics. Criti. Rev. Toxicol. 28:271-317

28. Liu J., Liu Y.P., Habeeru S.M., Klaassen C.D. (2000) Metallothionein-I/II null mice are sensitive to chronic oral cadmium-induced nephrotoxicity. Toxicol. Sci, $57: 167-176$

29. Liu Y., Liu J., Iszard M.B., Andrews G.K., Palmiter R.D., Klaassen C.D. (1995) Transgenic mice that overexpress MT-1 are protected from cadmium lethality and hepapoxicity. Toxicol. Applied Pharmacol. 135:222-228

30. Buhler R.H.O., Kagi J.H.R. (1974) Human hepatic metallothioneins. FEBS Let. $39: 229-234$

31. Lazo J.S., Kondo Y., Dellapiazza D., Michalska A.E., Choo K.H., Pitt B.R. (1995) Enhanced sensitivity to oxidative stress in cultured embryonic cells from transgenic mice deficient in metallothionein I and II genes. J. Biol. Chem. $270: 5506-5510$

32. Meister A. (1984) New aspects of glutathione biochemistry and transport: selective alteration of glutathione metabolism. Nutr. Rev. 42:397-410

33. Cherian M.G., Howell S.B., Imura N., Klassen C.D., Koropatnick J., Lazo J.S., Waalkes M.P. (1994) Contemporary issues in toxicology. Toxicol. Applied Pharmacol. 126:1-5

34. Woo E.S., Kondo Y., Watkins S.C., Hoyt D.G., Lazo J.S. (1996) Nucleophillic 
distribution of metallothionein in human tumor cells. Exp.Cell Res. 224:365-371

35. Cherian M.G. (1994) The significance of the nuclear and cytoplasmic localization of metallothionein in human liver and tumor cells. Environ. Health Perspect. $102: 131-135$

36. Shimoda R., Archanzar W.E., Que W., Nagamine T., Takagi H., Mori M., Waalkes M.P. (2003) Metallothionein is a potential negative regulator of apoptosis. Toxicol. Sci. 73:294-300

37. Gruiffre G., Barresi G., Sturniolo G.C., Sarnelli R. D’Inca R., Tuccari G. (1996) Immunohistochemical expression of metallothionein in normal human colorectal mucosa, in adenoma and in adenocarcinomas and their associated metastases. Histopathology 29:347-354

38. Sens M.A., Somji S., Garrett S.H., Beall C.L., Sens D.A. (2001) Metallothionien isoform 3 overexpression is associated with breast cancers having a poor prognosis. Am. J. Pathol. 159:21-26

39. Garrett S.H., Sens M.A., Shukla D., Nestor S., Somji S., Todd J.H., Sens D.A. (1999) Metallothionein isoform 3 expression in the human prostate and cancerderived cell lines. Prostate 41:196-202

40. Zelger B., Hittmair A., Schir M., Ofner C., Ofner D., Fritsch P.O., Bocker W., Jasani B., Schmid K.W. (1993) Immunohistochemically demonstrated metallothionein expression in malignant melanoma. Histopathology 23:257-263

41. McCluggage W.G., Maxwell P., Bharucha H. (1998) Immunohistochemical detection of metallothionein and MIB1 in uterine cervical squamous lesions. Int. J. 
Gynecol. Pathol. 17:29-35

42. Sauerbrey A., Zintl F., Volm M. (1994) Expression of metallothionein in initial and relapsed childhood acute lymphblastic leukemia. Ann. Haematol. 69:111-115

43. Ohshio G., Imamura T., Okada N., Wang Z.H., Yamaki K., Kyogoku T., Suwa H., Yamabe H., Imamura M. (1996) Immunohistochemical study of metallothionein in pancreatic carcinomas. J. Cancer Res. Clin. Oncol. 122:351-355

44. Saga Y., Hashimoto H., Yachiku S., Tokumitsu M., Kaneko S. (2002) Immunohistochemical expression of metallothionein in human bladder cancer: correlation with histopathological parameters and patient survival. J. Urol. $168: 2227-2231$

45. Lazo J.S., Pitt B.R. (1995) Metallothioneins and cell death by anticancer drugs. Annu. Rev. Pharmacol. Toxicol 35:635-653

46. Kratz F., Schutte M.T. (1998) Anticancer metal complexes and tumor targeting strategies. Cancer J. 11:176-182

47. Loehree P.J., Einhorn L.H. (1984). Cisplatin. Ann. Intern. Med. 100:704-713

48. Ohndorf U., Rould M.A., He Q., Pabl C.O., Lippard S.J. (1999) Basis for recognition of cisplatin-modified DNA by high-mobility-group proteins. Nature $399: 708-712$

49. Wood Jr. D.P., Klein E., Fair W.R., Chaganti R.S.K. (1993) Metallothionein gene expression in bladder cancer exposed to cisplatin. Modern Pathol. $6: 33-35$

50. Siegmund M.J., Marc C., Seemann O., Schummer B., Steidler A., Tmktomambetova L., Kohermann K., Rassweiler J., Alken P. (1999) 
Cisplatinresistant bladder carcinoma cells; enhanced expression of metallothioneins. Urol. Res. 27:157-163

51. Kotoh S., Naito S., Sakamoto N., Goto K., Kumazawa J. (1994) Metallothionein expression is correlated with cisplatin resistance in transitional cell carcinoma of the urinary tract. J. Urol. 152:1267-1270

52. Andrews P.A., Murphy M.P., Howell S.B. (1987) Metallothionein - mediated cisplatin resistance in human ovarian carcionoam cells. Cancer Chemother. Pharmacol. 19:149-154

53. Farnworth P., Hillcost B., Roos I. (1990) Metallothionein-like proteins and cell resistance to cis-dichlorodiamineplatinum(II) in L1210 cells. Canver Chemother. Pharmacol. 25:411-417

54. Mantosky G.M., Elliott E.A. (1981) Bladder cancer epidemiology. Epidemiol. Rev. 3:203-229

55. Kamat A.M., Lamm D.L. (1999) Chemoprevention of urological cancer. J. Urol.161:1748-1760

56. Landis S.H., Murray T., Bolden S., Wingo P.A. (1999) Cancer statistics, 1999. CA Cancer J. Clin. 49:8-31

57. Mommsen S., Aagaard J. (1983) Tobacco as a risk factor in bladder cancer. Carcinogenesis 4:335-338

58. Talaska G., Al-Juburi A.Z.S.S., Kadlubar F.F. (1991) Smoking related carcinogen-DNA adducts in biopsy samples of human urinary bladder: identification of $\mathrm{N}$-(deoxyguanosin-8-yl)-4-aminobiphenyl as a major adduct. 
PNAS 88:5350-5354

59. Lutzeyer W., Rubben H., Dahm H. (1982) Prognostic parameters in superficial bladder cancer: an analysis of 315 cases. J. Urol. 127:250-252

60. Matas N., Thygesen P., Stacey M., Risch A., Sim E. (1997) Mapping AAC1, AAC2, and AACP, the genes for arylamine $\mathrm{N}$-acetyltrasnferases, carcinogen metabolizing enzymes on human chromosome $8 \mathrm{p} 22$, a region frequently deleted in tumors. Cytogenet. Cell. Genet. 77:290-295

61. O’Flaherty E.J. (1998) Physiologically based models of metal kinetics. Criti. Rev. Toxicol. 28:271-317

62. Smith A.H., Lopipero P.A., Bates M.N., Steinmaus C.M. (2002) Arsenic epidemiology and drinking water standards. Science 296:2145-2146

63. Bates MN, Smith AH, Hopenhayn-Rich C. (1992) Arsenic ingestion and internal cancers. Am. J. Epidemiol. 135:462-476

64. Waalkes M.P. (2000) Cadmium carcinogenesis in review. J. Inorganic Biochem. 79:241-244

65. Zhao C.Q., Young M.R., Diwan B.A., Coogan T.P., Waalkes M.P. (1997) Association of arsenic-induced malignant transformation with DNA hypomethylation and aberrant gene expression. PNAS 94:10907-10912

66. Achanzar W.E., Diwan B.A., Liu J., Quader S.T., Webber M.M., Waalkes M.P. (2001) Cadmium-induced malignant transformation of human prostate epithelial cells. Cancer Res. 61:455-458

67. Sens M.A., Somji S., Lamm D.L., Garrett S.H., Slovinsky F., Todd J.H., Sens 
D.A. (2000) Metallothionein isoform 3 as a potential biomarker for human

bladder cancer. Environ. Health Perspec. 108:413-418

68. Petzoldt J.L., Leigh I.M., Duffy P.G., Sexon C. (1995) Immortalisation of human urothelial cells. Urol. Res. 23:377-380

69. Rossi M.R., Masters J.R.W., Park S., Todd J.H., Garrett S.H., Sens M.A., Somji S., Nath J., Sens D.A. (2001) The immortalized UROtsa cell line as a potential cell culture model of human urothelium. Environ. Health Perspec. 109:801-808

70. Waalkes M.P. (2000) Cadmium carcinogenesis in review. J. Inorganic Biochem. $79: 241-244$

71. Kitchin K.T. (2001) Recent advances in arsenic carcinogenesis: models of action, Animal model systems, and methylated arsenic metabolites. Toxicol. Appl. Pharmacol. 172:249-261 
MATERIALS AND METHODS 


\section{Cell Culture}

The UROtsa cells were cultured as previously described (1). Stock cultures of UROtsa cells were grown in T 75 flasks (Corning, Cat No.430720) in $15 \mathrm{ml}$ of regular medium or serum-free medium. The regular medium is Dulbecco's modified Eagles' medium (DMEM, Gibco-BRL Cat No 31600-75) with 5 \% serum (Hyclone Laboratories, Cat No SH30070-03). The serum-free medium is composed of a 1:1 mixture of DMEM and Ham's F-12 (Gibco-BRL Cat No 21700-109) supplemented with selenium (Collaborative Biomed Cat No 40201, 5 ng/ml), insulin (Collaborative Biomed Cat No 40310, $5 \mu \mathrm{g} / \mathrm{ml}$ ), transferrin (Collaborative Biomed Cat No 40204, $5 \mu \mathrm{g} / \mathrm{ml}$ ), hydrocortisone (Sigma Cat No H0135, 36.4 ng/ml), triiodothyronine (Sigma Cat No T5516, $4 \mathrm{pg} / \mathrm{ml}$ ) and epidermal growth factor (Gibco-BRL Cat No 13247-051, $10 \mathrm{ng} / \mathrm{ml}$ ).

The medium was filtered and kept at $4{ }^{\mathrm{O}} \mathrm{C}$. The serum-free medium was kept for only one week at $4^{\mathrm{O}} \mathrm{C}$. UROtsa cells were fed fresh growth medium every three days, and at confluence (normally 6-12 days post subculture), the cells were subcultured at a 1:4 ratio using $0.05 \%$ trypsin-0.02 \% EDTA (Gibco-BRL Cat No 25300-062). To subculture UROtsa cells, cells were washed with PBS. After removal of PBS, 5 ml Typsin-EDTA was added to the cells. The T75 flask was incubated on $37{ }^{\circ} \mathrm{C}$ warm plate until cells were detached. The cell suspension was collected into $50 \mathrm{ml}$ tube and centrifuged at 1000x RPM for 5 minutes at room temperature. The cell pellet was resuspended with $4 \mathrm{ml}$ cell culture medium and transferred $1 \mathrm{ml}$ of cell suspension to a new T75 flask.

\section{Stable Transfection of UROtsa Cells}

The coding sequence of the human MT-3 gene was obtained from human 
proximal tubule cell RNA by RT-PCR using MT-3 specific primers (2). The RT-PCR products were blunt-end ligated into the EcoRV site of pcDNA3.1/hygro (+) (Invitrogen, Carlsbad, CA). The human MT-1E containing pcDNA3.1/hygro (+) plasmid was made by the same strategy (2). This vector has a cytomegalovirus immediate-early promoter upstream of the multiple cloning site and a hygromycin B resistance gene driven by an SV40 early promoter. Fsp I restriction endonuclease which cuts the vector once at the bacterial amphicillin resistance gene was used to linearize the vector construct before transfection. The construct was transfected into UROtsa cells using Effectine transfection reagent (Qiagen, Valencia, CA). The day before transfection, cells were fed with fresh $5 \%$ FBS- Dulbecco's modified Eagles' (DME) medium. The parameters of the transfection were 1:10 plasmid to Effectine and $2 \mu \mathrm{g}$ DNA per $9.6 \mathrm{~cm}^{2}$ well. Cells $(6 \mu 1$ of $0.1 \mu \mathrm{g} / \mu 1$ linearized plasmid, $4.8 \mu 1$ of enhancer, $6 \mu 1$ of effectine) were incubated with the lipid-DNA complexes for 24 hours followed by normal growth medium for 24 hours at which time the cells were trypsinized and seeded at $10 \%$ confluence for selection in 30 $\mu \mathrm{g} / \mathrm{ml}$ hygromycin B. Clones were isolated using cloning rings (Sigma, St. Louis MO) and propagated in $30 \mu \mathrm{g} / \mathrm{ml}$ of hygromycin B. The stably transfected clones were identified by MT isoform specific RT-PCR and cultured with serum-free medium for further investigation.

\section{Exposure to cadmium and zinc}

The confluent cells in T75 flasks were fed with fresh serum-free medium 24 hours prior to subculture. The cells were seeded to 1:4 ratios into six-well plates and fed with 3 $\mathrm{ml}$ of fresh media every three days until $80 \%$ confluence. When cells had reached $80 \%$ 
of confluence, they were exposed to cadmium or zinc. The zinc and cadmium were dissolved in water at a concentration of $0.1 \mathrm{mg} / \mathrm{ml}$, filtered, divided into $1 \mathrm{ml}$ of aliquots and kept at room temperature. The concentrations of $\mathrm{CdCl}_{2}$ utilized were 1, 5, $9 \mu \mathrm{M}$ and those of $\mathrm{ZnSO}_{4}$ were 50 and $100 \mu \mathrm{M}$. The cells were fed with fresh growth medium containing the metals every 72 hours for 16 days. Protein and RNA were collected at the time points of $6,12,24,36,48,72$, and 96 hours after exposure to metals. MTT assay was performed at the same times.

\section{MTT Assay}

The MTT assay was performed to assess the cytotoxic effect of cadmium or zinc on UROtsa cells (3). The cellular viability was determined by measuring the production of formazan from MTT (3-[4, 5-dimethylthiazol-2-yl]-2, 5-diphenyltetrazolium bromide; Sigma, Cat No M-5655). MTT was dissolved in DMEM media ( $5 \mathrm{mg} / \mathrm{ml})$, filtered through a $0.2 \mu \mathrm{m}$ Acrodisk filter (Gelman Laboratory, Ref 4192), and kept at $-20{ }^{\circ} \mathrm{C}$ as 1 $\mathrm{ml}$ aliquots. The cells were cultured in six-well plates and $40 \mu \mathrm{l}$ of $5 \mathrm{mg} / \mathrm{ml}$ of MTT solution was added to each of the six-well plates. After 3.5 hours later in a $\mathrm{CO}_{2}$ incubator, the cells were rinsed with PBS buffer once and 1ml of acidic propanol ( $416 \mu 1$ of abs $\mathrm{HCl}$ in $50 \mathrm{ml}$ isopropanol) was added to each well. After 5 minutes, $200 \mu 1$ aliquots were applied in triplicate from each six-well plate and placed in a 96-well plate. The first two wells of 96-well plate contained $200 \mu 1$ of acidic propanol as a blank, and the absorbance of converted dye was measured by a Dynatech MR5000 plate reader (Dynatech Inc., Guernsey Channel Islands) at a wavelength of $570 \mathrm{~nm}$ with background subtraction of $630 \mathrm{~nm}$. 


\section{Isolation of RNA}

Cells were cultured in six-well plates and fed the day before harvesting RNA. Total RNA was isolated according to the protocol supplied with TRI REAGENT ${ }^{\mathrm{TM}}$ (Molecular Research Center, Inc. Cincinnati, OH). After removal of media, cells were incubated with $1 \mathrm{ml}$ TRI reagent for 10 minutes at room temperature. All cell lysates were kept at $-70{ }^{\circ} \mathrm{C}$ before further investigation. The cell lysates were thawed at room temperature and added to $0.1 \mathrm{ml} \mathrm{BCI} \mathrm{reagent.} \mathrm{After} \mathrm{vortexing} \mathrm{for} 20$ seconds, cell lysates were kept at room temperature for 15 minutes. After centrifugation at $4{ }^{\mathrm{O}} \mathrm{C}$ for 15 minutes at $12,000 \mathrm{xg}$, the upper aqueous phase was transferred into a new tube. After adding 0.5 volume of isopropanol, mixtures were incubated at $-20{ }^{\mathrm{O}} \mathrm{C}$ overnight. Mixtures were centrifuge at $4{ }^{\circ} \mathrm{C}$ for 15 minutes. The pellets were washed with $70 \%$ ethanol twice and dried for 10 minutes. Cell pellets were resuspended in $25 \mu 1$ of RNAfree water and stored at $-70{ }^{\circ} \mathrm{C}$. For RNA quantitation, $2 \mu 1$ RNA solution and $98 \mu 1$ Tris buffer (1 mM Tris-HCl, pH 8.0) were mixed thoroughly and read at 260 and $280 \mathrm{~nm}$ with a spectrophotometer. The total RNA was diluted to $0.5 \mu \mathrm{g}$ RNA / $3 \mu \mathrm{l} \mathrm{dH} 2 \mathrm{O}$. Before being used for RT-PCR, RNA solutions were kept at $-70{ }^{\circ} \mathrm{C}$.

\section{RT-PCR}

Total RNA was diluted to $0.5 \mu \mathrm{g} / 3 \mu \mathrm{l}$ with water. Total RNA was reverse transcribed with random hexanucleotide primers and subjected to PCR using the Gene/Amp RT-PCR core kit (Applied Biosystems, Forster City, CA) according to the manufacturer's protocol. The composition of reverse transcription master mix was $5 \mathrm{mM}$ $\mathrm{MgCl}_{2}, 1 \mathrm{x}$ PCR Buffer II (50 mM KCl and $10 \mathrm{mM}$ Tris-HCl, $\mathrm{pH}$ 8.3), $1 \mathrm{mM}$ dATP, 1 
mM dCTP, 1 mM dTTP, 1 mM dGTP, $2.5 \mathrm{mM}$ random hexamers, $1 \mathrm{U} / \mu 1$ RNase inhibitor and 2.5 $\mathrm{U} / \mu 1 \mathrm{MuLV}$ reverse transcriptase. Aliquots of $1.5 \mu 1$ of RNA samples $(0.5 \mu \mathrm{g} / 3 \mu \mathrm{l})$ were placed in sterile PCR reaction tubes on ice. After adding $8.5 \mu 1$ of master mix reagents, each reaction tube was gently mixed. The thermocycler (GeneAmp PCR system 9700, Applied Biosystems) ran for a single cycle of $25^{\circ} \mathrm{C}$ for 10 minutes, $42{ }^{\circ} \mathrm{C}$ for 20 minutes, $99^{\circ} \mathrm{C}$ for 5 minutes. The reverse transcribed product was either used for PCR or kept at $-20^{\circ} \mathrm{C}$.

PCR master mix was composed of $2 \mathrm{mM} \mathrm{MgCl} 2,1 \times$ PCR Buffer II, specific upper and lower PCR primers, and 1.25 U AmliTag DNA polymerase with total $40 \mu 1$ of volume with water. Primers for MT-1E were 5' GCTTGTTCGTCTCACTGGTG 3', and 5' CAGGTTGTGCAGGTTGTTCTA 3' (product size, 284 bp); for MT-1X, 5' TCTCCTTGCCTCGAAATGGAC 3', and 5' GGGCACACTTGGCACAGC 3' (product size, 151 bp); for MT-2A, 5' CCGACTCTAGCCGCCTCTT 3', and 5' GTGGAAGTCGCGTTCTTTACA 3' (product size, 259 bp). The primers for MT-3 were, upper 5' CCGTTCACCGCCTCCAG 3', and lower 5' CACCAGCCACACTTCACCACA 3' (product size, $325 \mathrm{bp}$ ). The primers for the determination of glyceraldehyde 3-phosphate dehydrogenase (GAPDH) were (upper and lower, respectively), 5' TGAAGGTCGGAGTCAACGGATTTGGT 3' and 5' CATGTGGGCCATGAGGTCCACCAC 3' (product size, 983bp. Clonetech Cat No 5406). The primers for the pcDNA3.1hygro(+) vector were 5'CGGATCCACTAGTCCAGTGTG3' and 5'ACGGGCCCTCTAGACTCG 3'. All MT primers were obtained from Gibco-BRL. Final concentration of primers for PCR was 0.1 
$\mu \mathrm{M}$ except MT-1X primers. The final concentration of MT-1X primers for PCR was 0.4 $\mu \mathrm{M}$. After adding $40 \mu 1$ of master mix into reverse transcribed product, tubes were mixed gently. All PCR reactions were started with a $95{ }^{\circ} \mathrm{C}$ hot start for 2 minutes immediately prior to cycling. For all PCR reactions the thermocylcer was programmed to cycle at $99{ }^{\circ} \mathrm{C}$ for 5 minutes, $68{ }^{\circ} \mathrm{C}$ for 30 seconds using GeneAmp PCR System 9700 machine.

Aliquots of $15 \mu 1$ of PCR products were taken at 25, 30, 35 or 40 PCR cycles from each reaction tube and combined with $1.5 \mu 1$ of $10 \mathrm{x}$ gel loading buffer. Controls for each PCR included a no-template control where water was added instead of the RNA and a noreverse transcriptase control where water was added instead of the enzyme. For gel analysis, $2 \%$ agarose (Perkin-Elmer, Cat No 930-2774) was mixed with $0.5 x$ TBE buffer (Gibco-BRL, Cat No 15546-013) and heated in a microwave until the agarose was

dissolved completely. After cooling at $60{ }^{\circ} \mathrm{C}$, ethidium bromide $(0.5 \mu \mathrm{g} / \mathrm{ml})$ was added to TBE buffer and poured into a gel mold. Ten $\mu$ of RT-PCR product in loading dye was loaded into each well and $10 \mu 1$ of Hi-Lo TM DNA marker was used for size marker. The gels were run at $120 \mathrm{mV}$ for approximately 1-2 hours. The RT-PCR products were visualized on a UV transilluminator. Digital images of the gels were obtained by KODAK Professional DCS 420 digital camera interfaced with Adobe Photoshop TM software, and the intensity of the RT-PCR product bands were quantitated as integral optical densities (IODs) by Kontron KS 400 image analysis software (Carl Zeiss Vision).

\section{Protein Preparation from cultured cells}

The cells were fed with media the day before harvesting proteins. The cells in sixwell plate were rinsed with PBS twice, collected with $500 \mu 1$ of fresh made cell lysis 
buffer $\left(10 \mathrm{mM}\right.$ Tris-HCl, $\mathrm{pH}$ 8.0, $1 \mathrm{mM}$ DTT) and kept at $-70{ }^{\circ} \mathrm{C}$ until further investigation. The cell lysates were thawed at $37{ }^{\circ} \mathrm{C}$ in a water bath and frozen with liquid $\mathrm{N}_{2}$. This step was repeated three times. The cell lysates were passed through a 22 gauge needle for several times. After centrifuging for 5 minutes at $12,000 \mathrm{xg}$, the supernatant was transferred into a new tube. Protein was quantitated by the Bradford method (BioRad, Ca No 500-0006). The protein was diluted to $1.5 \mu \mathrm{g} / 10 \mu \mathrm{l}$ in cell lysis buffer and kept at $-70^{\circ} \mathrm{C}$ until further investigation.

\section{Protein Immuno-dot Blot}

An immunoblot procedure was described previously $(4,5)$. For MT-1 and 2 dot blot, $0.75 \mu \mathrm{g}$ of total protein was used. The protein samples were arranged in triplicate in 96-well plates, and each sample well contained $10 \mu \mathrm{l}(0.75 \mu \mathrm{g})$ of total protein. For the MT-1 and MT-2 standards ( $0,0.5,1,2,4,7,10$, and 15 ng MT protein), 1.5 times the final concentration of MT-1 standard protein (Sigma) was arranged in two rows, with each standard well contained $0.75 \mu \mathrm{g}$ of protein extract from the MT null cell line. The final volume of standard and sample wells was brought up to $75 \mu 1$ with phosphate buffer. The $75 \mu 1$ of $3 \%$ glutaraldehyde was added into the each well and mixed well. Until loaded on dot blot apparatus, 96-well plates were wrapped with saran brand wrap to prevent evaporation of samples.

For MT-3 dot blot, $1.5 \mu \mathrm{g}$ of total protein was applied. For MT-3 standard protein $(0,0.01,0.02,0.04,0.06,0.1,0.2$, and $0.3 \mathrm{ng}$ protein), was prepared with 1.5 times conjugated synthetic peptide (Sigma) and $1.5 \mu \mathrm{g}$ of BSA protein.

A Sequi-Blot TM PVDF membrane (Bio-Rad, Cat No 162-0182) was soaked in 
methanol for 30 seconds. After washing with $\mathrm{dH}_{2} \mathrm{O}$, the membrane was soaked in PBS until used for the immuno-blot. The dot blot apparatus was assembled and the lower chamber of apparatus was filled with approximately $50 \mathrm{ml}$ of PBS buffer with a syringe. The syringe remained attached to the drain tube while the PVDF membrane was carefully placed over the holes of the plastic adapter without any air bubbles. The top plate was secured to the lower chamber and the wells were filled with $600 \mu 1$ of PBS buffer. The plunger of syringe was pulled out until the wells began draining by gravity. The syringe was removed and PBS buffer was drained completely. Hundred $\mu 1$ of the samples were applied to the membrane. After the samples drained completely, $200 \mu$ l of PBS was applied to the membrane twice and then drained completely. The membrane was removed from the dot blot apparatus, soaked in PBS and kept at $4{ }^{\circ} \mathrm{C}$ for overnight. The membrane was incubated in $50 \mathrm{ml}$ of blocking agent $(10 \%$ nonfat milk in PBS buffer) for 1 hour while shaking a $200 \mathrm{rpm}$. After washing quickly with $50 \mathrm{ml}$ of PBS three times, the membrane was incubated three times in PBS buffer for 15 minutes. The membrane was incubated with $50 \mathrm{ml}$ of primary antibody for 1 hour. The antibody against MT-1 and MT-2 was E9 antibody (DAKO, Code No M639). This antibody was diluted to 1:100 with incubation solution ( $1 \% \mathrm{BSA}, 0.02 \% \mathrm{NaN}_{3}$ in PBS). The primary antibody solution against MT-3 solution was composed of $0.187 \mu \mathrm{g} / \mathrm{ml}$ of primary antibody with $1 \% \mathrm{BSA}$ and $0.02 \% \mathrm{NaN}_{3}$ in PBS buffer. After three times quick washing with $50 \mathrm{ml}$ of PBS buffer, the membrane was rinsed three times with PBS for 15 minutes. After incubation with the secondary antibody for 1 hour, the membrane was washed as above. The secondary antibody for MT-1 and MT-2 was 1:500 dilution of anti- 
mouse IgG antibody (Promega, Cat No S372B) with incubation solution (0.4 \%BSA, $0.02 \% \mathrm{NaN}_{3}$ in PBS buffer). The secondary antibody for MT-3 was 1:500 dilution of anti-rabbit antibody (Promega, Cat No S3831) with incubation buffer $(0.4 \%$ BSA, $0.02 \% \mathrm{NaN}_{3}$ in PBS buffer). The membrane was rinsed with alkaline phosphatase buffer (10 mM Tris- $\mathrm{HCl}, \mathrm{pH} 8.0)$ for 5 minutes. Colorimetric detection of the alkaline phosphatase conjugated secondary antibodies was performed by VectorR Blue alkaline phosphatase substrate kit III (Vector Laboratories, Cat No SK-5300). The solutions 1, 2, and 3 were added respectively into $25 \mathrm{ml}$ of alkaline phosphatase buffer and mixed gently. The detection solution was poured on the membrane. The dot blot was developed until the proper color was visible. After the membrane was washed with water, it was left to air dry on a piece of paper towel for overnight. After the membrane was scanned as a digital image, the intensity of dots was measured by KS400 software. The intensity was quantitated by linear regression in Microsoft Excel.

The antibody against MT-3 protein was generated by immunizing New Zealand White rabbits with the dodecapeptide GGEAAEAEAEKC (corresponding to MT-3 amino acid, 53-64, which contains the MT-3 unique amino acid insert) conjugated through the C-terminal cysteine $\mathrm{SH}$ group to keyhole limpet hemocyanine using maleimidobenzoyl-N-hydroxysuccinimde ester. The MT-3 antibody was affinity purified using the dodecapeptide linked to SulfoLink gel (Pierce, Rockford, IL) through the Cterminal cysteine residue.

\section{Chronic exposure to arsenic or cadmium of UROtsa cells}

$\mathrm{NaAsO}_{2}$ was prepared as a $1 \mathrm{mM}$ stock solution with water and added to cell 
culture medium before feeding cells. The passage numbers of UROtsa cells in serum and serum-free medium were 88 and 51, respectively. Cells were fed with $1 \mu \mathrm{M}$ arsenic containing fresh medium once every three days. Two months later cells were fed every other day with extra glucose because cells would die due to cellular toxicity resulting from acidic $\mathrm{pH}$ of the medium. Approximately three months after exposure to arsenic, cells began growing fast. Therefore, the cells were subcultured 1:10 ratio after three months exposure. The untreated UROtsa cells were usually subcultured 1:4 ratio and reached $100 \%$ of confluence in 7-8 days after subculturing. These chronically arsenic exposed UROtsa cells were subcultured 1:10 ratio and reached 100\% of confluence in 56 days after subculturing.

UROtsa cells were cultured on 6 well plates both with regular and serum free media. Upon reaching $90 \%$ confluence, $1 \mu \mathrm{M} \mathrm{CdCl}_{2}$ was added into each well. After cells reached confluence, cells were subcultured at 1:4 ratio in T75 flasks. Transfer resulted in $90 \%$ cell death followed by regrowth of the cells. The cells were fed with fresh media containing metals once every three days. One month later, after the cells were transferred into the T75 flask, extra glucose $(1 \mathrm{mg} / \mathrm{ml})$ was added to cell culture medium and two months later, cells were split 1:10 ratio. The RNA and protein samples were collected every four serial subcultures.

\section{Growth rate of transformed UROtsa cells}

Cells were cultured in $\mathrm{T} 75$ flask with or without $1 \mu \mathrm{M} \mathrm{CdCl}_{2}$ or $1 \mu \mathrm{M} \mathrm{NaAsO}_{2}$. After being trypsinized and resuspended, cells were seeded to a 1:20 ratio in six-well plates with or without metals. The exposed UROtsa cells were used as a control. For 
rescued condition, exposed cells were cultured without arsenic or cadmium for two weeks. Then cells were seeded to 1:20 ratio in 6 well-plates and maintained without arsenic or cadmium and monitoered the growth rate by recording absorbance at $570 \mathrm{~nm}$ every 24 hours for 6 days by MTT assay. The growth rate, expressed as doubling time, was calculated from the slope of linear regressed plots of LN (cell number) vs. time (6). The absorbance at $570 \mathrm{~nm}$ was measured instead of cell numbers in this study; slope was calculated after absorbance value was multiplied by 100 and integrated. The integrated value was used for regression and the $\mathrm{x}$ value was used for slope.

\section{Soft Agar Assay}

Soft agar assays were performed using standard procedures (7). $1.01 \%$ of noble agar in DMEM was heated until dissolved on the hot plate. After mixing with the same volume of $1.01 \%$ noble agar and cell culture media, $5 \mathrm{ml}$ mixture $(0.55 \%$ agar $)$ was poured in $60 \mathrm{~mm}$ plates and solidified at room temperature. The remaining mixtures were kept at $45{ }^{\mathrm{O}} \mathrm{C}$ water bath to prevent solidification. After trypisinization, cells were resuspended in culture media and counted. $2 \times 10^{5}$ cells in medium were mixed with half volume of $0.55 \%$ noble agar containing medium. $1.5 \mathrm{ml}$ of $2 \times 10^{5}$ cells in $1.5 \mathrm{ml}$ of $0.275 \%$ noble agar containing medium was poured onto the $5 \mathrm{ml}$ of bottom layer of $0.55 \%$ noble agar containing medium in $60 \mathrm{~mm}$ dish. The $60 \mathrm{~mm}$ dishes were put inside the box which has two water contained beakers. This moisturized box prevented dehydration of soft agar in $60 \mathrm{~mm}$ dishes. Then this box was put back to the cell culture incubator. The next day cells were observed under microscope to make sure all cells were single. One week later, cells were observed under the microscope to see how many cells 
formed colonies. Three weeks later, colonies containing more than 10c ells were photographed and counted.

\section{Nude Mice and Transformed Cell Injection}

A nude mouse tumorigenicity assay was performed (8). Athymic nude mice ( $\mathrm{NCr}$ $\mathrm{nu} / \mathrm{nu}$ ) were obtained through the National Cancer Institute. All animal care procedures were in strict accordance with state of the art animal resource facility (20,600 GSF 1, 7950 NSF). All animals were fed with LabDiet5001 (TestDiet). Four different transformed cell types were injected into nude mice: $1 \mu \mathrm{M}$ cadmium exposed UROtsa cells in serum medium, $1 \mu \mathrm{M}$ cadmium exposed UROtsa in serum-free medium, $1 \mu \mathrm{M}$ arsenic exposed UROtsa in serum medium, and $1 \mu \mathrm{M}$ arsenic exposed UROtsa in serumfree medium. Transformed cells were cultured in T75 flasks. The cells were trysinized and centrifuged briefly. The cells were resuspended with $1 \mathrm{ml}$ of PBS buffer. The resuspended cells were inoculated subcutaneously in the dorsal thoracic midline of 11 approximately eight-week-old female nude mice for each transformed cell lines. All mice were sacrificed 5-9 weeks after injection. Each tumor sample was divided into three pieces for histology, RT-PCR and protein dot blot. For histology, tumor tissue was kept in $10 \%$ formalin after removal from mouse. For RT-PCR and protein dot blot, tumor

tissue was kept in liquid $\mathrm{N} 2$ before transferring to $-70{ }^{\circ} \mathrm{C}$ for further investigation. $\mathrm{PC}-3$, the prostate cancer cell line, was used as a control for this experiment.

\section{Hematoxylin and Eosin Staining}

The tumor was removed from the nude mouse and cut out as a small piece of tissue (usually $10 \mathrm{~mm} \times 10 \mathrm{~mm} \times 3 \mathrm{~mm}$ ) and fixed overnight in $10 \%$ neutral formalin. 
The tissues were incubated in two washes of $10 \%$ formalin for one minute each, $70 \%$ alcohol for one minute, $95 \%$ alcohol for one minute and fourth washes of $100 \%$ alcohol for one minute four times. Dehydrated tissues were cleared in xylene, infiltrated and embedded in paraffin, and sectioned with a sharp knife at $5 \mu \mathrm{m}$ thick as serial sections. The serial sections were put on covered slide and dried. The slides were kept at room temperature until further investigation. The slides were deparaffinzed by three times incubation of clean xylene for three mintues, followed by two washes from absolute ethanol to 95,80 , and $70 \%$ ethanol, and washed in distilled water for two minutes. The slides were incubated with hematoxylin for seven minutes, dipped 10 times in tap water, dipped 3-5 times in acidic alcohol (3\% $\mathrm{HCl}$ in $70 \%$ ethanol), and washed in tap water. Tissue was dipped 3-5 times in lithium carbonate, washed in tap water and stained in eosin for 45 seconds. The tissue was dehydrated by washed in 95 and $100 \%$ alcohol twice. Finally, tissue was incubated with xylene twice for three minutes and covered with cover slip and dried at room temperature.

\section{References}

1. Rossi M.R., Masters J.R.W., Park S., Todd J.H., Garrett S.H., Sens M.A., Somji S., Nath J., Sens D.A. (2001) The immortalized UROtsa cell line as a potential cell culture model of human urothelium. Environ. Health Perspec. 109:801-808

2. Mididoddi S., McGuirt J.P., Sens M.A., Todd J.H., Sens D.A. (1996) Isoformspecific expression of metallothionein mRNA in the developing and adult human kidney. Toxicol. Lett. 685:17-27

3. Denizot F., Lang R. (1986) Rapid colorimetric assay for cell growth and survival. 
Modifications to the tetrazolium dye procedure giving improved sensitivity and reliability. J. Immunol. Methods. 89:271-277

4. Garrett S.H., Sens M.A., Shukla D., Nestor S., Somji S., Todd J.H., Sens D.A. (1999) Metallothionein isoform 3 expression in the human prostate and cancerderived cell lines. Prostate 41:196-202

5. Garrett S.H., Sens M.A., Shukla D., Flores L., Somji S., Todd J.H., Sens D.A. (2000) Metallothionein isoform 1 and 2 gene expression in the human prostate: down-regulation of MT-1X in advance prostate cancer. Prostate 43:125-135

6. Dutta R., Sens D.A., Somji S., Sens M.A., Garrett S.H. (2002) Metallothionein isoform 3 expression inhibits cell growth and increases drug resistance of PC-3 prostate cancer cells. Prostate 52:89-97

7. Hackett A.J., Smith H.S., Springer E.L., Owens R.B., Nelson-Rees W.A., Riggs J.L., Gardner M.B. (1977) Two syngeneic cell lines from human breast tissue: the aneuploid mammary epithelial (Hs578T) and the diploid myoepithelial (Hs578Bst) cell lines. J Natl. Cancer. Inst. 58:1795-1806.

8. Achanzar W.E., Diwan B.A., Liu J., Quader S.T., Webber M.M., Waalkes M.P. (2001) Cadmium-induced malignant transformation of human prostate epithelial cells. Cancer Res. 61:455-458 
The Effect of Metallothionein Isoform 3 Expression in UROtsa Cell Line 


\section{Introduction}

Recent studies demonstrate that MT-3 is up-regulated in human bladder cancer and might serve as a biomarker for bladder cancer because it is not expressed in normal urothelium but is overexpressed in most bladder cancers, with expression correlating directly to increasing tumor grade $(1,2)$. Immunohistochemical analysis showed that MT-3 staining was intense in both carcinoma in situ and high-grade bladder cancer, and low to moderate in low-grade cancers and dysplastic lesions. This was based on determining the localization and expression of the MT-3 protein and mRNA in fresh and archival biopsy specimens from patients undergoing differential diagnosis for a variety of bladder disorders. While these observations suggest an important role for MT-3 in human bladder cancer, there are only limited data in humans and animals for development of a hypothesis to explain the up-regulation of MT-3 gene expression.

The UROtsa cell line was derived from the normal urothelium lining the ureter of a 12-year-old girl and was immortalized by SV40 large T-antigen (3). The cells did not acquire characteristics of neoplastic transformation as noted by lack of colony formation in the soft agar and growth of tumors in nude mice (3). The previous study showed that propagation of the UROtsa cell line on serum-free growth medium results in expression of structural features of differentiated urothelium (4). Ultrastructure analysis has shown detailed organization of these multilayered mounds and freeze-fracture has revealed the presence of specialized intercellular junctions including zonula occluden. These findings are significant in that UROtsa appears to have similar characteristics of in vivo human urothelium. Previous studies also showed that the UROtsa cell line didn't express MT 
isoform 3 and thus this cell line was suggested as a useful model system for determining functional consequence of forcing MT-3 overexpression on the normal urothelial cell (4).

\section{Objectives of the Study}

The first goal of this study was to see the effect of MT-3 overexpression in the normal human bladder epithelial cell line. The second goal was to develop the UROtsa cell system as a model for the overexpression of MT-3 in bladder cancer and the MT stress response of normal urothelium.

\section{Results}

The UROtsa cell line was stably transfected with MT-3 gene under control of the cytomegalovirus (CMV) promoter, or the blank vector without the MT-3 gene. The stable transfectants were selected by $30 \mu \mathrm{g} / \mathrm{ml}$ hygromycin B. The selected clones were cultured in serum-free medium for further investigation. As confirmed in the previous study, MT-3 mRNA was not detected in the blank vector transfectants and parental UROtsa cells by 40 cycles of PCR at an input of $500 \mathrm{ng}$ total RNA (Fig 1A). Immuno-dot blot analysis of the corresponding protein sample from these wild type UROtsa cells demonstrated no detectable MT-3 protein (data not shown). Four MT-3 transfected clones were selected for the further investigation. MT-3 mRNA was detected at 25 cycles of PCR and 500 ng of total RNA inputs (Fig 1A). RT-PCR of glyceraldehydes 3-phospate dehydrogenase (gapdh) in all these cells was performed as a control of input of amount of total RNA (Fig 1B). In contrast to the high levels of MT-3 mRNA expression, the MT-3 protein was not detected in these MT-3 transfected clones (data not shown). To confirm this data, sixteen more clones were selected and analyzed by RT-PCR and immuno-dot 

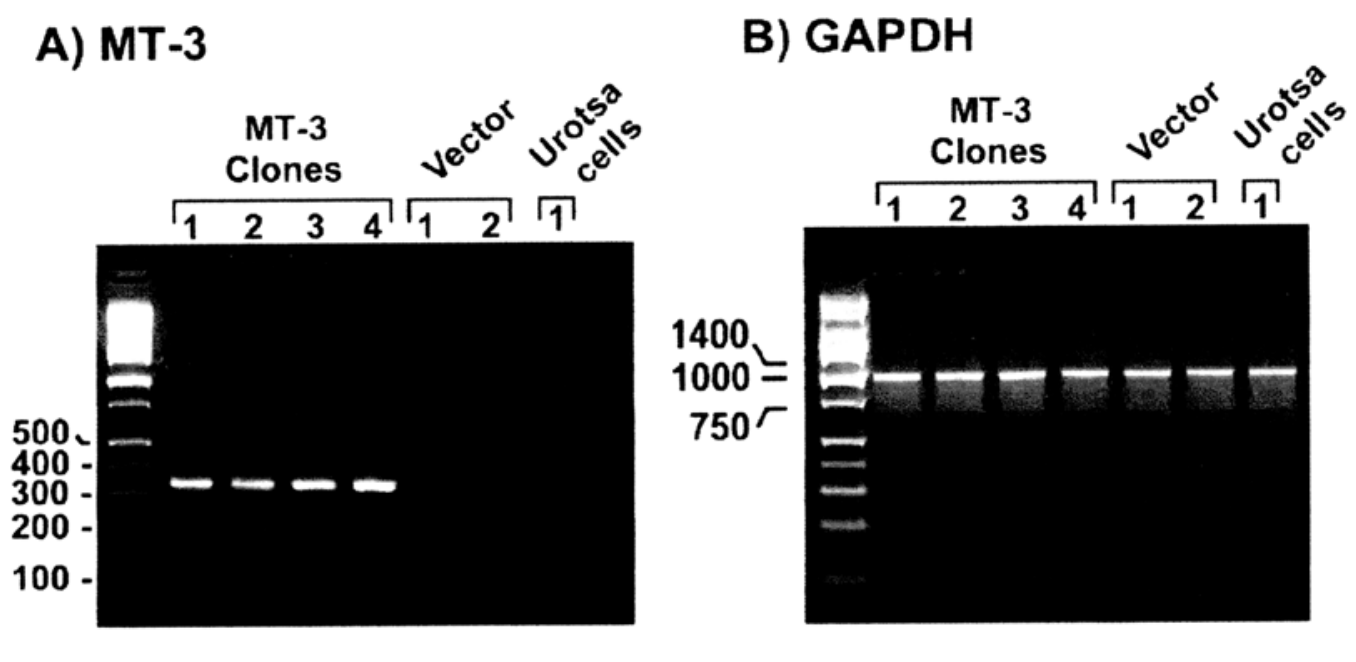

Fig. 1. Stable overexpression of MT-3 mRNA in UROtsa cells. Total RNA was isolated from nontransfected cells and clones of MT-3 or control vector-transfected cells and RT-PCR was performed. (A) MT-3 mRNA was detected from each of the four MT-3 transfected clones at 25 cycles of PCR with MT-3 specific primers. MT-3 mRNA was not detected from nontransfected and control vector-transfected clones at 40 cycles with MT3 specific primers. (B) RT-PCR for the housekeeping gene, glyceraldehydes 3-phosphate dehydrogenase (gapdh), performed at 30 cycles with gapdh specific primers. The total RNA was used from the same RNA in (A). 
blot for MT-3 protein. All selected clones of MT-3 transfected UROtsa cells showed the expression of MT-3 mRNA (Fig 2A). All sixteen MT-3 transfected clones did not express noticeable levels of MT-3 protein (Fig 2B). To confirm that the MT-3 gene inserted into pcDNA3.1/Hygro (+) plasmid construct was functional, the plasmid construct was transfected into PC-3 (prostate cancer), HS578T (breast cancer), HK-2 (kidney), and MCF-7 (breast cancer) cell lines. RT-PCR data confirmed the successful isolation of MT3 transfected clones from each cell line. The immuno-dot blot data also showed successful expression of MT-3 protein from the alternative cell lines (Fig 2B). These results demonstrate that the low accumulation of MT-3 protein in transfected UROtsa clones was neither because of MT-3 plasmid misconstruction nor problems with the MT3 immuno-dot blot detection system. The UROtsa cells containing the MT-3 vector were named UROtsa(MT3) cells and those containing the unmodified vector named UROtsa(3.1).

There are several indications that induction of MT protein synthesis is blocked by RNA synthesis inhibitors even though mRNA level is increased (5). The half-lives of MT are tremendously different when bound to various heavy metals (6). These studies suggest that MT accumulation is also regulated by post-transcriptional processes or protein stabilities. This hypothesis also is supported by previous studies that exposure of cells to cadmium and copper can increase the level of the MT-1 and MT-2 at the posttranscriptional level by stabilizing the protein against degradation $(7,8,9)$. Even though MT-3 protein is synthesized in UROtsa(MT3) cells, protein may be degraded rapidly due to lack of metals to bind. To test this hypothesis, UROtsa(MT3) and 
(A)

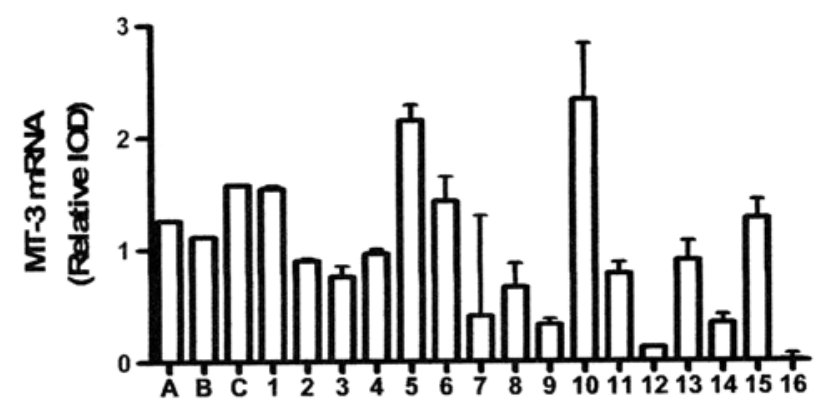

(B)

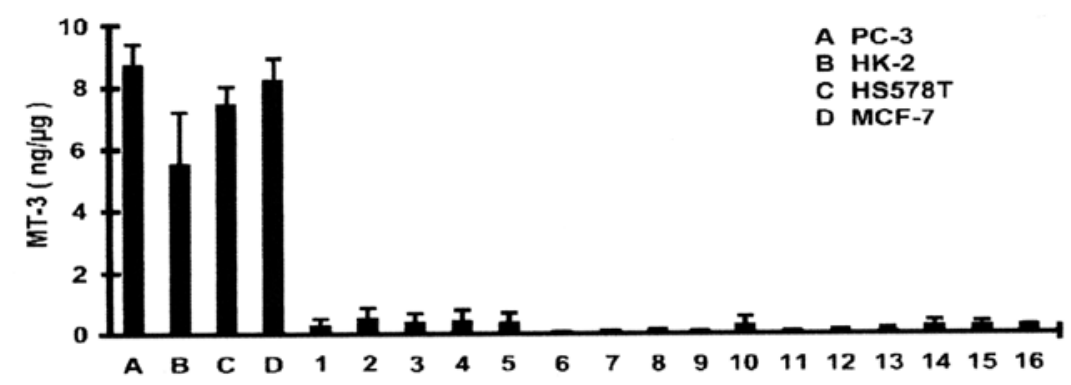

Fig. 2. Expression of MT-3 in 16 MT-3 gene transfected UROtsa clones compared to other MT-3 gene transfected cell lines. (A) The mRNA expression assessed by RTPCR and reported as relative IOD (IOD of the MT-3 RT-PCR product band at 30 cycles normalized to that of GAPDH at 30cycles). (B) MT-3 protein expression was measured by immuno-dot blot. PC-3 is prostate cancer cell line, HK-2 is kidney cell line, and HS578T and MCF-7 are breast cancer cell lines. Triplicate RT-PCR and immuno-dot blot were analyzed and shown are the mean and standard error. 
UROtsa(3.1) cells were exposed to metals and MT-3 protein was measured. The cells were cultured with 1,5 and $9 \mu \mathrm{M}$ concentration of cadmium in serum-free medium up to 16 days. Cell viability was determined by the MTT assay. MTT assay data showed no cellular toxicity with $1 \mu \mathrm{M} \mathrm{CdCl}$, intermediate level of cell death with $4 \mu \mathrm{M} \mathrm{CdCl}_{2}$ and a high level of cell death with $9 \mu \mathrm{M} \mathrm{CdCl} 2$ in both UROtsa(MT3) and UROtsa(3.1) cells (Fig 3A.,3B). There was no difference in sensitivity to cadmium between UROtsa(MT3) and UROtsa(3.1) cells. The total RNA and proteins were collected from these cadmium exposed cells for RTPCR and immuno-dot blot. Previous study showed that MT-1E, MT$1 \mathrm{X}$ and MT-2A were expressed in UROtsa cell line (4). As expected, mRNAs of MT-1E, MT-1X and MT-2A were induced by cadmium in both cell types (Fig 4, Fig 5). Exposure of UROtsa(MT3) cells to cadmium had no effect on the expression of the MT-3 protein compared to UROtsa(3.1) cells at any point in the time course up to 96 hrs (Fig. 6). In contrast, an identical exposure to cadmium produced significant increases in the MT-1 and MT-2 protein at all concentrations of cadmium both UROtsa(MT3) and UROtsa(3.1) cells (Fig. 7).

Zinc is an essential metal during cell proliferation and differentiation (10). Intracellular levels of zinc are critical for induction of the MT genes since metal response element transcription factor -1 (MTF1) is a zinc-finger transcription factor and is well known as trans-acting element for MT gene expression $(11,12)$. Several studies have shown that zinc containing MT shows more resistance to protease than cadmium containing MT and cadmium and zinc may regulate MT in differently (13). To test whether or not zinc may stabilize MT-3 protein, UROtsa(MT3) and UROtsa(3.1) cells 
(A)

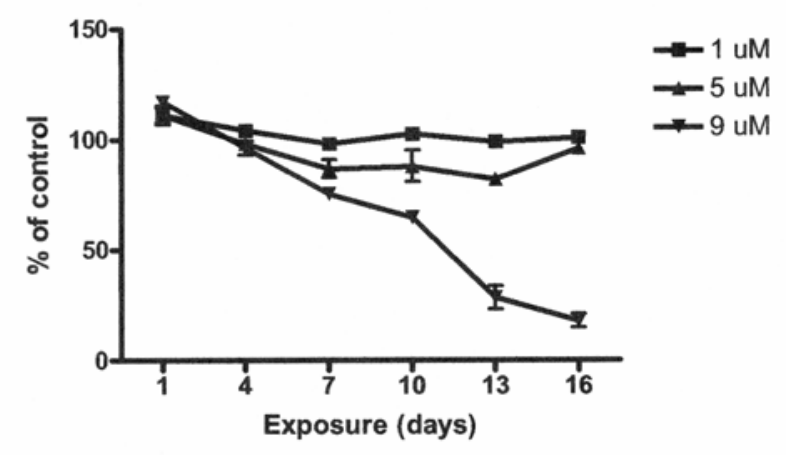

(B)

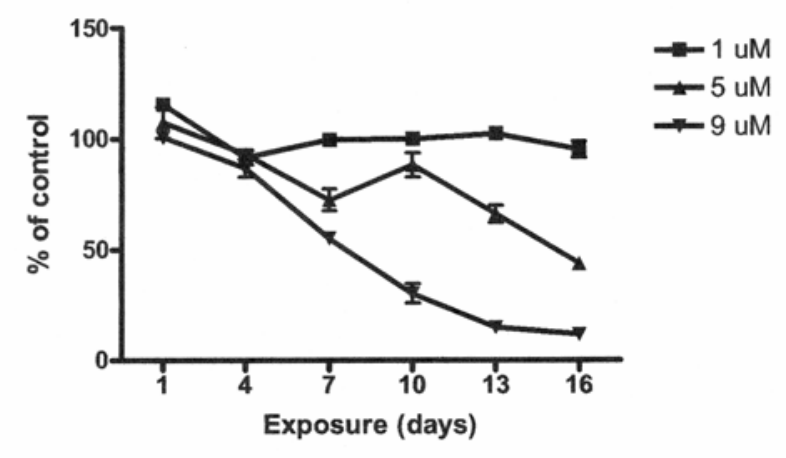

Fig. 3. Viability of UROtsa(3.1) and UROtsa(MT3) cells exposed to cadmium chloride. Cell viability was determined by MTT assay and all determinations were made in triplicate. The graphed values are expressed as percentages of mean absorbance of treated cells divided by the mean absorbance of control cells for each triplicate determination. (A)Viability profiles of UROtsa(3.1) (B) UROtsa(MT3). Triplicate of immuno-dot blot were analyzed and shown are the mean and standard error. 


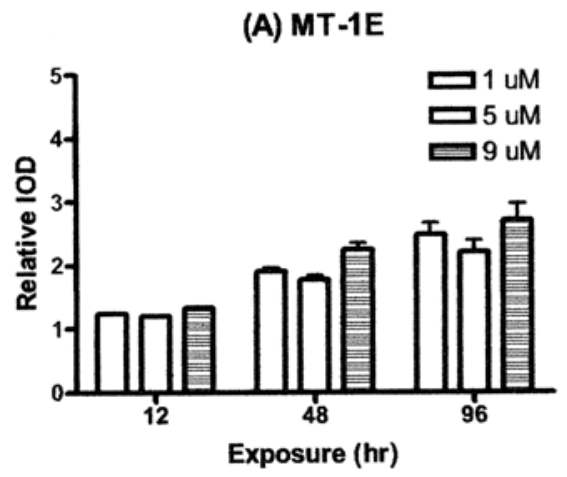

(B) MT-1X

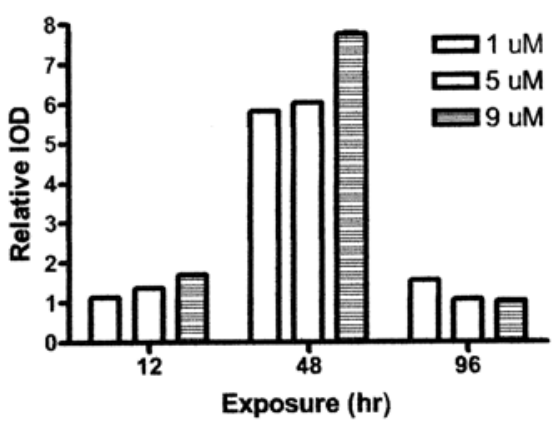

(C) MT-2A

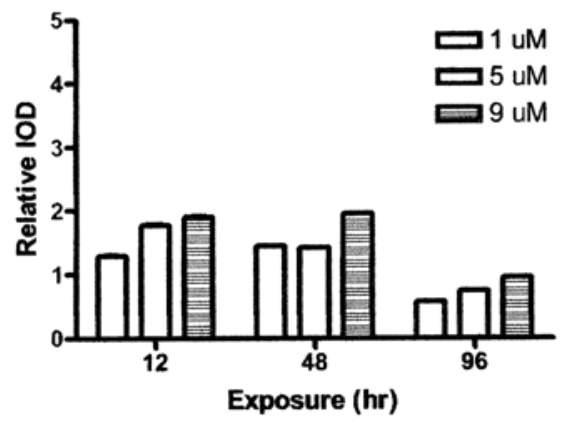

Fig. 4. Expression of metallothionein isoforms in UROtsa(3.1) cells exposed to cadmium chloride The cells were exposed to three levels of cadmium for up to 96 hours and harvested at the indicated time points. (A) Expression of MT-1E mRNA at 33 cycles. (B) Expression of MT-1X mRNA at 28 cycles (C) Expression of MT-2A mRNA at 28 cycles. The IOD of the MT RT-PCR product normalized to that of GAPDH (25 cycles) and divided by control IOD. Triplicate culture samples were analyzed and shown are the mean and standard error. 


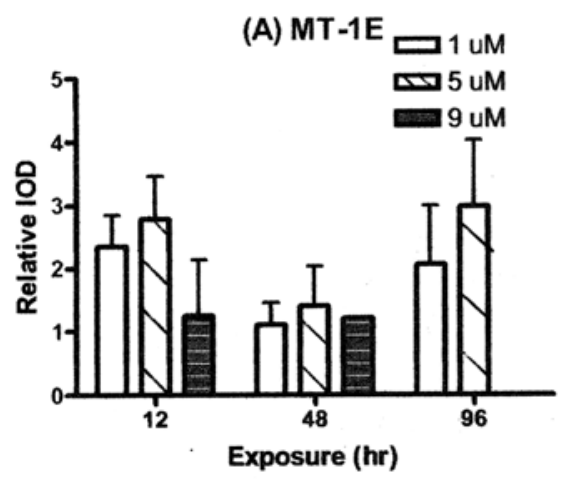

(B) MT-1X
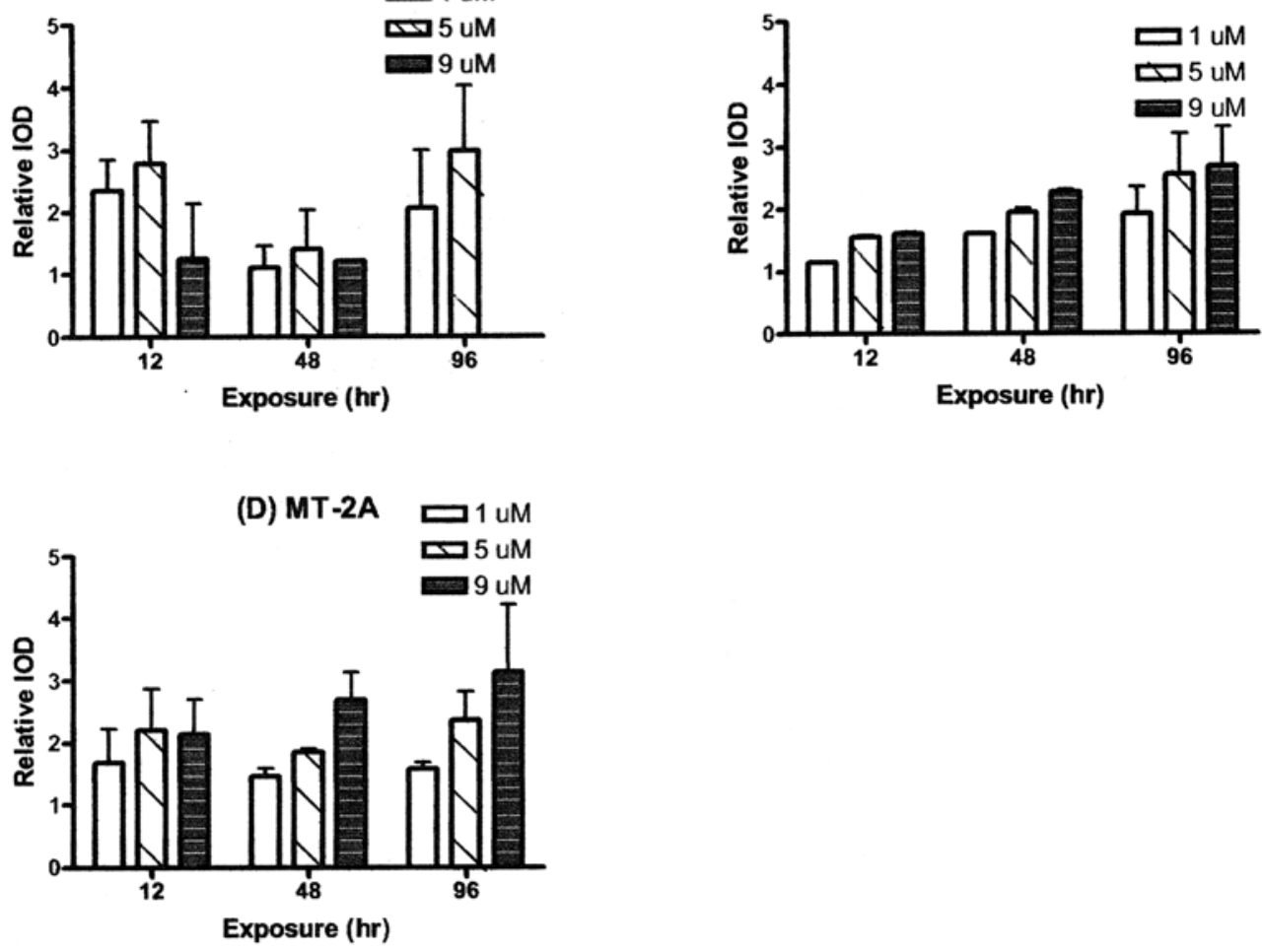

Fig. 5. Expression of metallothionein isoforms in UROtsa(MT3) cells exposed to cadmium chloride. The cells were exposed to three levels of cadmium for up to 96 hours and harvested at the indicated time points. (A) Expression of MT-1E mRNA at 33 cycles. (B) Expression of MT-1X mRNA at 28 cycles (C) Expression of MT-2A mRNA at 28 cycles. The IOD of the MT RT-PCR product normalized to that of GAPDH $(25$ cycles) and divided by control IOD. Triplicate culture samples were analyzed and shown are the mean and standard error. 


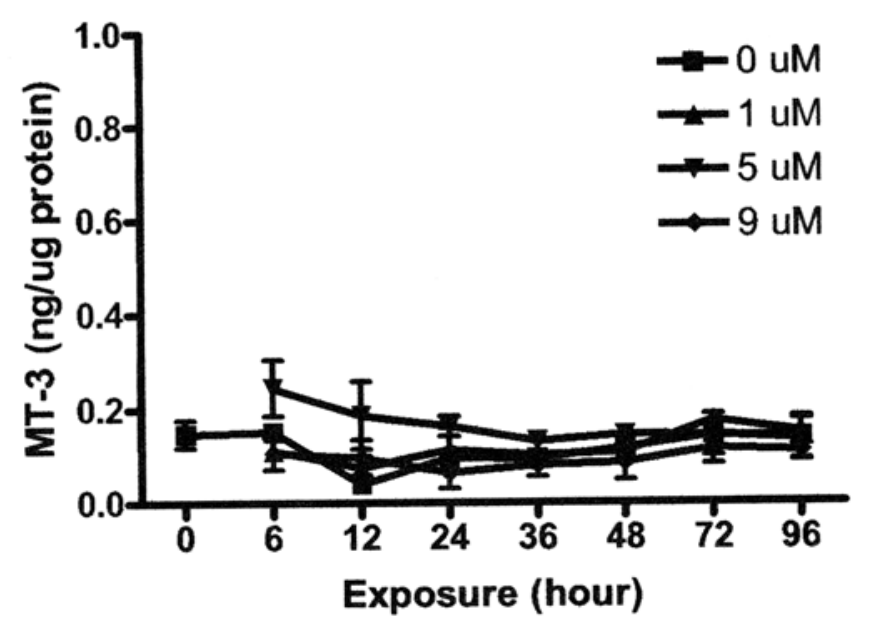

Fig. 6. Expression of metallothionein-3 in UROtsa(MT3) cells exposed to cadmium chloride. The cells were exposed to three levels of cadmium for up to $96 \mathrm{~h}$ and harvested at the indicated time points. Levels of MT-3 protein were determined using an immunodot- blot with an MT-3 specific antibody. Shown are the means and SE of triplicate cell samples. 
(A)

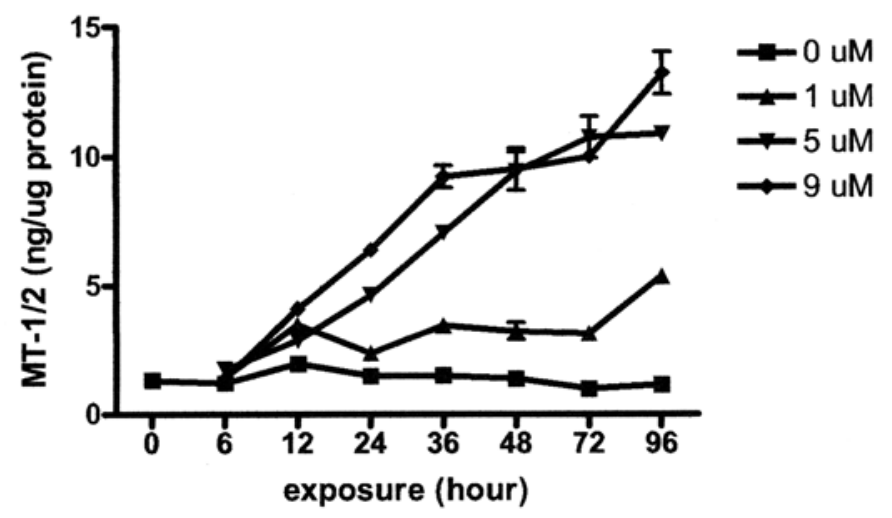

(B)

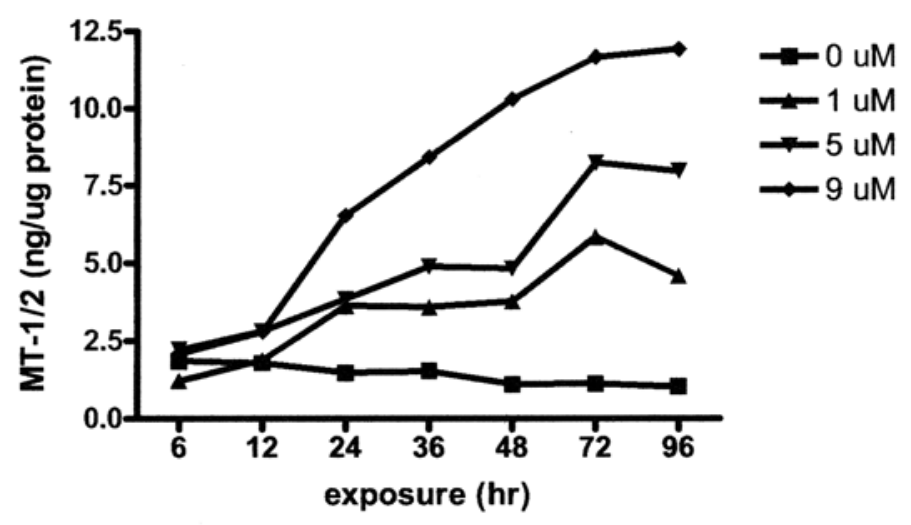

Fig. 7. Expression of metallothionein-1/2 protein in UROtsa(3.1) (A) and

UROtsa(MT3) (B) cells exposed to cadmium chloride. Nanograms of MT-1/2 protein expressed at various time points in UROtsa cells exposed to three levels of cadmium up to $96 \mathrm{~h}$ and harvested at the indicated time points. Levels of MT-1 and 2 proteins were determined using an immuno-dot blot with an E9 antibody. Shown are the means and SE of triplicate cell samples. 
were exposed to zinc chloride for up to 72 hours. MTT assay showed that 50 and $100 \mathrm{uM}$ zinc were not lethal (Fig. 8). MT-3 protein did not accumulate (Figs.9, 10). In contrast, MT-1 and MT-2 proteins were induced by zinc up to four folds.

The conclusion drawn from studies with UROtsa(MT3) cells is that transfected MT-3 gene is successfully transcribed but not translated very efficiently. As discussed earlier, MT-3 is different from other metallothionein isoforms in many ways. Therefore, it was of interest to determine whether or not other MT isoforms are translated in UROtsa cell line. The MT-1E is one of the common and well studied isoforms. To confirm that MT-1E had been successfully transfected into UROtsa cells, pcDNA3.1/Hygro $(+)$ specific primer was used for RT-PCR because the UROtsa cells showed basic level of MT-1E mRNA. RT-PCR for 30 cycle data showed that MT1E was successfully transfected and transcribed (Fig. 11). The MT-1E transfected UROtsa cells were named UROtsa(MT1E). The UROtsa(MT1E) cells were exposed to 1,5 , and $9 \mu \mathrm{M} \mathrm{CdCl} 2$ up to 96 hours. The MTT assay showed no toxic effect of cadmium at any time course (Fig. 12). The MT-1 and MT-2 proteins in UROtsa(MT1E) were increased more than $60 \%$ compared to the basal levels in UROtsa(3.1) (Fig. 7A, Fig. 13). This result demonstrated that the inserted MT-1E gene was transcribed and translated in the UROtsa cell line.

\section{Discussion}

The initial goal of this study was to investigate that the consequences of the stable transfection of MT-3 gene into immortalized human urothelial cell line. The stable transfection of MT-3 resulted in the expected overexpression of MT-3 mRNA but the level of MT-3 protein was similar to that of the background levels found in the parental 
(A)

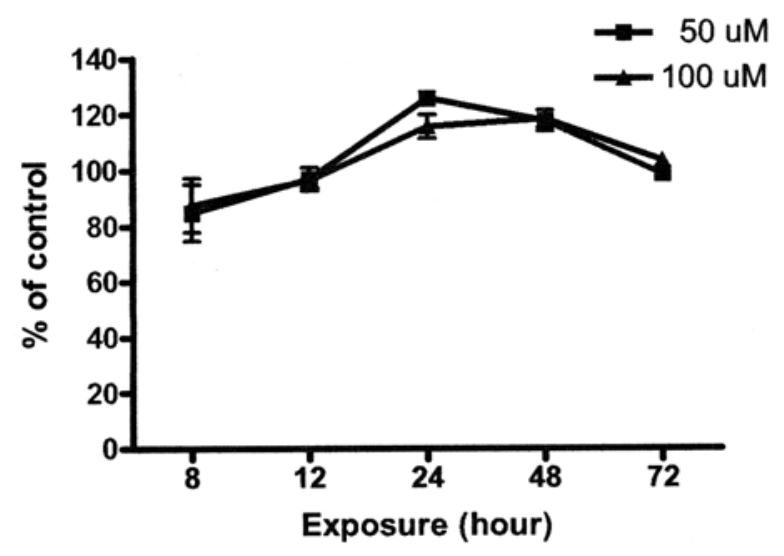

(B)

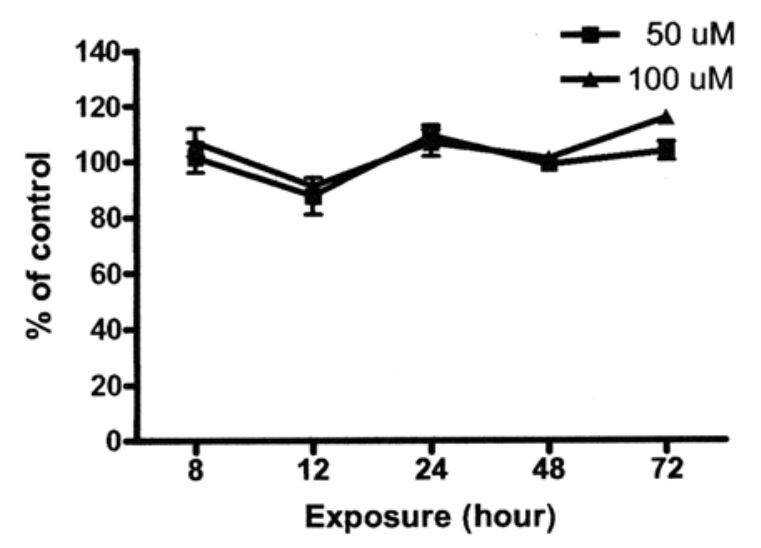

Fig. 8. Viability of UROtsa(3.1) (A) and UROtsa(MT3) (B) cells exposed to zinc. Cell viability was determined by MTT assay and all determinations were in triplicate. The graphed values are expressed as percentages of the mean absorbance of treated cells Divided by the mean absorbance of control cells for each triplicate determination. 

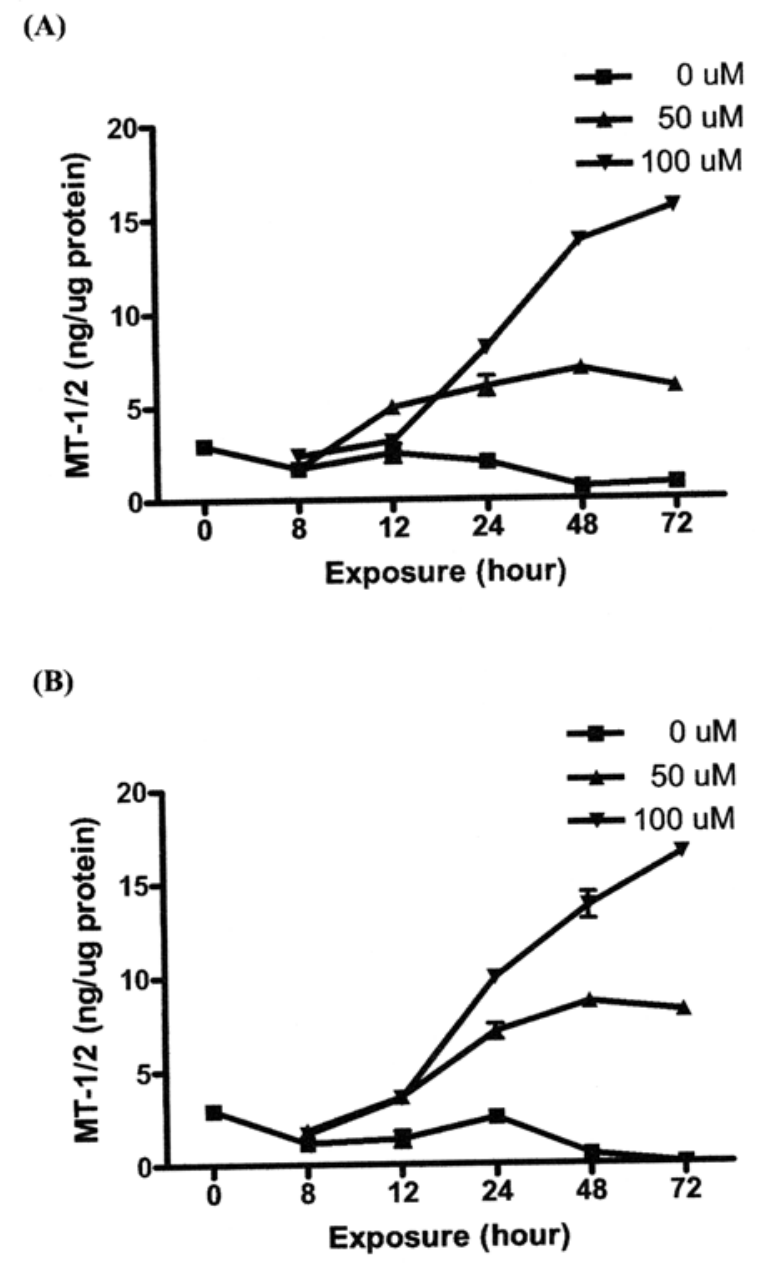

Fig. 9. Expression of metallothionein-1/2 protein in UROtsa(3.1) (A) and UROtsa(MT3) (B) cells exposed to zinc. Nanograms of MT-1/2 protein expressed at various time points in UROtsa cells exposed to three levels of cadmium up to $72 \mathrm{~h}$ and harvested at the indicated time points . Levels of MT-1 and 2 proteins were determined by an immuno-dot blot with an E9 antibody. Shown are the means and SE of triplicate cell samples. 
(A)

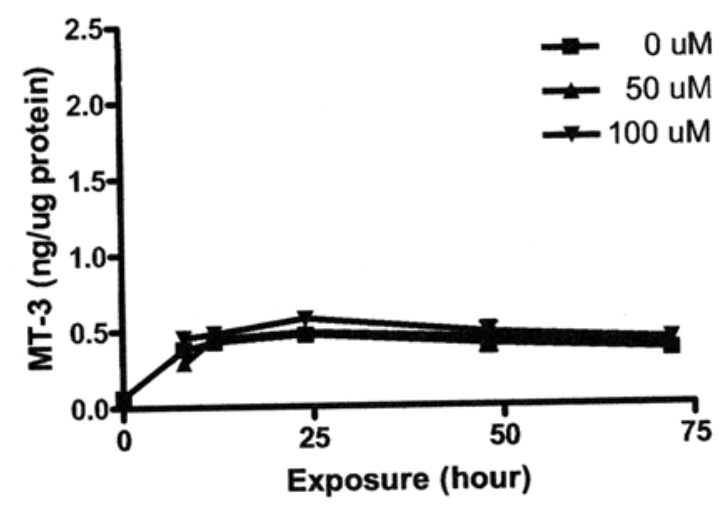

(B)

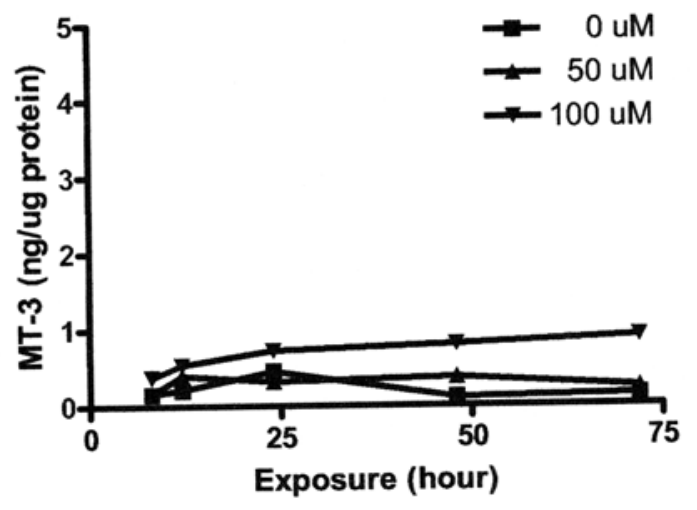

Fig. 10. Expression of metallothionein-3 in UROtsa(3.1) (A) and UROtsa(MT3) (B) cells exposed to zinc. Cells were exposed to three levels of zinc chloride for up to $72 \mathrm{~h}$ and harvested at the indicated time points. Levels of MT-3 protein were determined using an immuno-dot blot with an MT-3 specific antibody. Shown are the means of triplicate cell samples. 


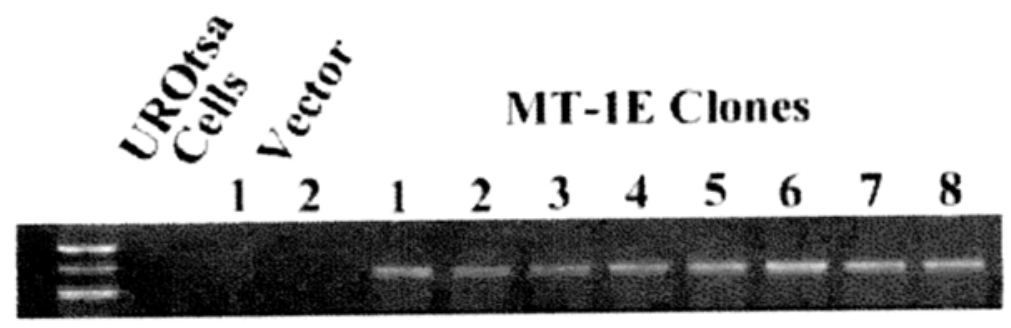

Fig 11. Stable overexpression of MT-1E mRNA in UROtsa cells. Total RNA was isolated from nontransfected cells and clones of MT-1E or control vector-transfected cells and RT-PCR was performed. PCR was performed by using pcDNA3.1 especific vector. MT-1E mRNA was detected from MT-1E transfected clones at 30 cycles of PCR. MT-3 mRNA was not detected from nontransfected and control vector-transfected clones at 30 cycles. 


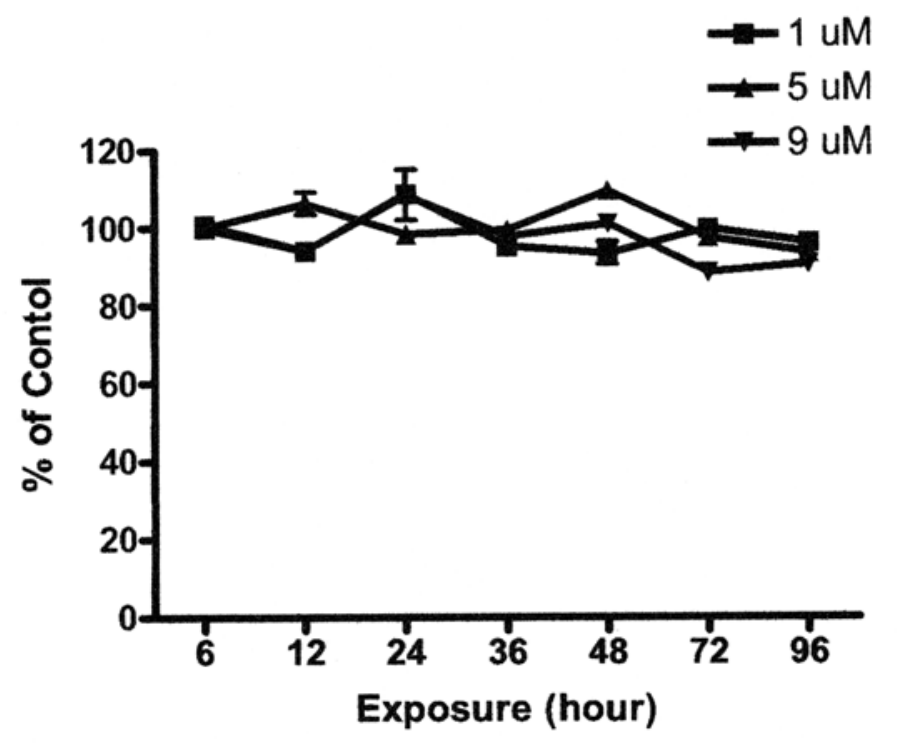

Fig 12. Viability of UROtsa(MT1E) cells exposed to cadmium chloride. The cell viability of MT-1E transfected UROtsa cells was determined by MTT assay. The absorbance at $570 \mathrm{~nm}$ for each of the three treatments, as well as untreated cells were measured in triplicate at hours $6,12,24,36,48,72$ and 96. Each of the treatments $(1,5$ and $9 \mu \mathrm{I}$ cadmium chloride) was plotted as separate lines expressed as a percentage of mean absorbance of treatments divided by mean absorbance of untreated controls for each triplicate determination. Shown are the means and standard error of triplicate cell samples. 


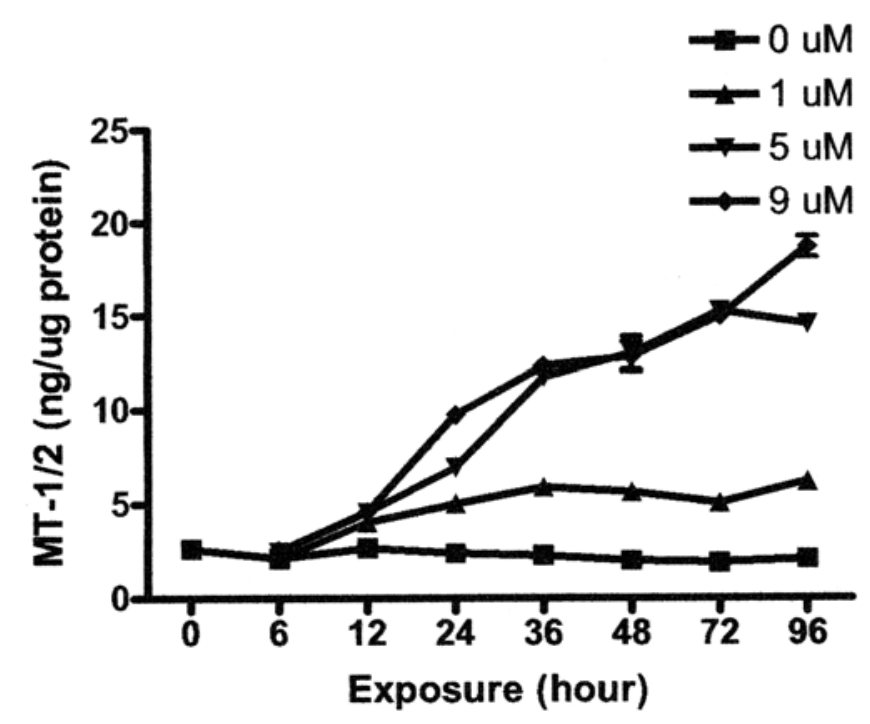

Fig 13. Effect of cadmium on MT-1/2 protein expression in UROtsa(MT1E) cells. The MT-1E transfected UROtsa cells were exposed 1,5 , and $9 \mu \mathrm{M}$ cadmium and cell lysates were prepared at $0,6,12,24,36,48,72$ and 96 hours for determination of MT-1/2 protein levels. 
cells and blank vector control. This finding was unexpected since other studies using the identical vector and transfection protocol did result in the overexpression of both MT-3 mRNA and protein. Recent rodent studies demonstrated that there was no clear relationship between MT-1 and MT-2 mRNA and protein levels (8). In adult mouse injected with copper or cadmium, MT protein levels in liver did not change even though mRNA expression increased. In contrast, MT protein levels in kidney increased with increased mRNA levels. It is well-documented for MT-1 and MT-2 isoforms that in addition to transcriptional control, there is also a component of post-transcriptional control that depends on the metal saturation state of the MT-1 and MT-2 proteins $(14,15)$. MT protein is susceptible to degradation when devoid of metal, and stabilizes against degradation upon metal binding and saturation of the binding sites. These studies suggest that the failure of the stably transfected UROtsa cells to accumulate MT-3 protein in the presence of elevated MT-3 mRNA might operate through a similar mechanism involving metal saturation and stability of the MT-3 protein. This hypothesis was tested in the present study and there was no effect on MT-3 protein accumulation when MT-3 transfected UROtsa cells were exposed to cadmium. This finding demonstrates that metal saturation of MT-3 protein is not a potential mechanism to explain the posttranscriptional restriction of MT-3 protein accumulation in the transfected UROtsa cells.

In contrast, the MT-1 and MT-2 proteins were accumulated to higher levels under identical conditions of cadmium exposure in the MT-1E transfected UROtsa cells. Several cell lines transfected with MT-1E did not show any difference from parental or blank vector transfected cells. These findings are the first indication that some cell types 
possess a specific mechanism for the post-transcriptional regulation of MT-3 protein expression.

Although the exact mechanism of post-transcriptional regulation of MT-3 protein is still unknown, there is evidence that its activity in cell culture may be defined by the tissue of origin. The stable transfection of MT-3 gene in several cancer cell lines such as PC-3 (prostate caner), MCF-7 (breast cancer) and Hs578T (breast cancer) resulted in decreased cell growth rate due to overexpression of MT-3 protein $(16,17)$. The primary human proximal tubule (HPT) cells expressed MT-3 mRNA and protein by stable transfection and accumulated increased protein upon exposure to cadmium. The immortalized HK-2, proximal epithelial cells, showed increased MT-3 protein upon exposure to cadmium in MT-3 transfected clones and formed domes that may involve vectoral active transport (18). The MCF-10 (immortalized breast cell line) failed to make MT-3 protein after stable transfection (publication under preparation). These studies suggest that regulation of MT-3 expression may involve specific function of MT-3 proteins in different cell types.

In conclusion, MT-1E and MT-3 genes were stably trasnfected into the UROtsa cells. The transfected MT-1E gene was efficiently translated in the UROtsa cells but was not MT-3 gene. Even though the transfected MT-3 gene was transcribed in the UROtsa cells, the MT-3 gene appears to be regulated at the post-transcriptional level in the UROtsa cells. This study indicates that the regulation of MT-3 expression is different from other MT isoforms. 


\section{References}

1. Saga Y., Hashimoto H., Yachiku S., Tokumitsu M., Kaneko S. (2002)

Immunohistochemical expression of metallothionein in human bladder cancer:

correlation with histopathological parameters and patient survival. J Urol $168: 2227-2231$

2. Sens M.A., LammD.L., Garrett S.H., Slovinsky F., Todd J.H., Sens D.A. (2000) Metallothionein isoform 3 as a potential biomarker for human bladder cancer. Environ. Health Perspect. 108:413-418

3. Petzoldt J.L., Leigh I.M., Duffy P.G., Sexon C. (1995) Immortalisation of human urothelial cells. Urol. Res. 23:377-380

4. Rossi M.R., Masters J.R.W., Park S., Todd J.H., Gareett S.H., Sens M.A., Somji S., Nath J., Sens D.A. (2001) The immortalized UROtsa cell line as a potential cell culture model of human urothelium. Environ. Health Perspec. 109:801-808

5. McCormick C.C., Salati L.M., Goodridge A.G. (1991) Abundance of hepatic metallothionein mRNA is increased by protein-synthesis inhibitors. Biochem. J. $273: 185-188$

6. Kershaw W.C., Klaassen C.D. (1992) Degradation and metal composition of hepatic isometallothioneins in rats. Toxicol. Applied Pharmacol. 112:24-31

7. Vasconcelos M.H., Tam SC, Beattie J.H., Hesketh J. (1996) Evidence for differences in the post-transcriptional regulation of rat metallothionein isoforms. Biochem. J. 315:665-671

8. Vasconcelos M.H., Tam S.C., Hesketh J, Reid M, Beattie J.H. (2002) Metal-and 
tissue-dependent relationship between metallothionein mRNA and protein. Toxicol. Appl. Pharmacol. 182:91-97

9. Lehman L.D., Poisner A.M. (1984) Induction of metallothionein synthesis in cultured human trophoblasts by cadmium and zinc. J. Toxicol. Environ. Health $14: 419-432$

10. Vallee B.L. (1995) The function of metallothionein. Neurochem. Int. 27:23-33

11. Richards M.P., Cousins R.J. (1975) Mammalian zinc homeostasis: requirement for RNA and metallothionein synthesis. Biochem. Biophys. Res. Comm. 64:12151223

12. Davis S.R., Cousins R.J. (2000) Metallothionein expression in animals: a physiological perspective in function. J. Nutr. 130:1085-1088

13. Solis W.A., Childs N.L., Weedon M.N., He L., Nebert D.W., Dalton T.P. (2002) Retrovirally expressed metal response element-bind transcription factor-1 normalizes metallothionein-1 gene expression and protects cells against zinc, but not cadmium, toxicity. Toxicol. Applied Pharmacol. 178:93-101

14. Choudhuri S., McKim J.M.Jr., Klassen C.D. (1992) Role of hepatic lysosomes in the degradation of metallothionein. Toxicol Appl Pharmacol. 115:64-71

15. Moffatt P., Denizeau F. (1997) Metallothionein in physiological and physiopathological processes. Drug Metab. Rev. 29:261-307

16. Dutta R., Sens D.A., Somji S., Sens M.A., Garrett S.H. (2002) Metallothionein isoform 3 expression inhibits cell growth and increases during resistance of PC-3 prostate cancer cells. Prostate 52:89-97 
17. Gurel V., Sens D.A., Somji S., Garrett S.H., Nath J., Sens M.A. (2003) Stable transfection and overexpression of metallothionein isoform 3 inhibits the growth of MCF-7 and Hs578T cells but not that of T-47D or MDA-MB231 cells. Breast Cancer Res. Treat. 80:181-191

18. Kim D., Garrett S.H., Sens M.A., Somji S., Sens D.A. (2000) Metallothionein isoform 3 and proximal tubule vectoral active transport. Kidney Int. 61:464-472 
In vitro Transformation of UROtsa Cell Line by Chronic Exposure to Arsenic or Cadmium 


\section{Introduction}

Human exposure to hazardous chemicals is common due to their wide usage in industry and their persistence in the environment. Cadmium is an important industrial and environmental pollutant and is classified as a carcinogen by the International Agency for Research on Cancer and the US National Toxicology Program based on an association between occupational or environmental cadmium exposure and development of cancers of the lung, prostate, kidney, liver, stomach and bladder (1). Even though the epidemiological studies suggest a link between cadmium exposure and various human cancers, mechanisms of cadmium-induced carcinogenesis are still unclear (1). Since cadmium is not considered a mutagen, several indirect genotoxic carcinogenic mechanisms have been suggested for the altered gene expression and disruption of cellcell adhesion. Several studies demonstrated that cadmium may replace $\mathrm{Ca} 2+$ in cellcell adhesion, resulting in disruption of cell-cell adhesion and changes of gap junctional communication (2-4). Chronic exposure to cadmium caused overexpression of cellular proto-oncogenes including c-fos, c-jun and c-myc and resulted in change of cellular proliferation and modification of signal transduction pathway (5). The environmental contaminant arsenic is considered as a human carcinogen. Arsenic occurs naturally in drinking water with levels ranging up to thousands of ppb. It is reported that ingestion of arsenic leads to skin lesions and an elevated risk of skin cancer (6). The arsenic ingestion through drinking water is associated with an elevated number of micronuclei in epithelial bladder cells in exposed populations (7). This indicates cytogenetic damage to bladder cells and strengthens the evidence that arsenic may cause bladder cancer and other 
internal cancers. The epidemiological observation supports that arsenic is also associated with various cancers in humans, including tumors of the lung, skin, bladder and liver (8). Several studies demonstrated that low-level of chronic exposure to arsenic causes malignant transformation of epithelial cells by global DNA hypomethylation and aberrant gene expression (9-11). Interestingly, arsenic has also been used as an effective chemotherapeutic agent in the treatment of certain human cancers especially in leukemia (12). The chronic exposure to low concentrations of arsenic induces cell transformation, whereas higher concentrations of arsenic induce cell apoptosis $(13,14)$.

Several cell culture systems have been developed to investigate the carcinogenic mechanism of environmental chemicals in various cancers (15). The bladder cancer is an environmentally induced cancer and this cancer is clearly linked with environmental chemicals and smoking. Since the major risk factor for bladder cancer is occupational and environmental exposure to chemicals, it is important to establish in vitro transformation model comprised of human urothelial cells, the common target cells for the these environmental contaminants $(16,17)$. Several reports have demonstrated the successful transformation of human uroepithelial cell lines by chronic exposure to various potential carcinogens but none have demonstrated the development of arsenic or cadmium-induced in vitro transformation model system in human urothelial cell line $(18,19)$.

The UROtsa cell line was isolated from a primary culture of normal human urothelium through immortalization with a construct containing the SV40 large T antigen (20). It proliferates in serum-containing growth medium as a cell monolayer with little evidence of uroepithelial differentiation. When these cells are cultured in serum-free cell 
culture medium, they are differentiated and express known features that strongly

resemble in situ urothelium (21). These findings suggest that the UROtsa cells grown with serum-free medium could be a valuable tool for studying environmental insult to the human urothelium in general and in particular the stress response to environmental pollutants. The first aim of this study was to determine whether or not chronic exposure to low concentration of arsenic or cadmium results in in vitro transformation of human urothelial cell line. The second aim of this study was to develop an in vitro transformation model system for arsenic or cadmium induced transformation in human urothelial cells.

\section{Results}

In this study, chronic exposure to arsenic or cadmium showed no significant morphological difference of UROtsa cells compared with unexposed UROtsa control cells (Fig. 14). The cellular morphology is another good indicator for proliferative ability of cells. Highly dividing cells show a characteristic small and morphologically homogeneous cell type. By contrast, slowly dividing or senescent cells are larger with a high incidence of morphological heterogeneity (22). The larger and morphological heterogeneous cells appeared at the earlier stages of exposure to the two chemicals. These cells were not common at later stages of exposure.

To determine the change in the rate of growth in UROtsa cells following chronic exposure to arsenic or cadmium, growth rates were determined by MTT assay for $1 \mu \mathrm{M}$ cadmium treated UROtsa cells in serum medium and serum-free medium for seven months, $1 \mu \mathrm{M}$ arsenic treated UROtsa cells in serum medium and serum-free medium for 
(A)

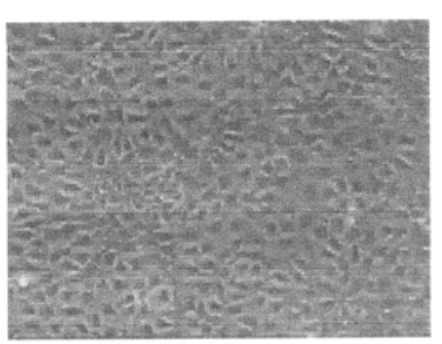

(C)

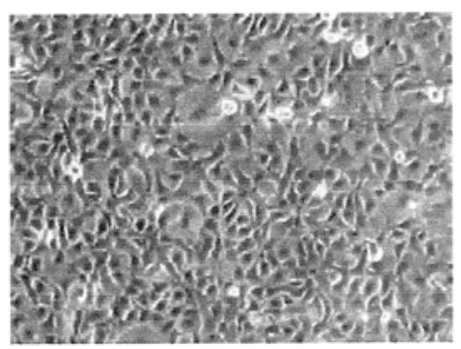

(E)

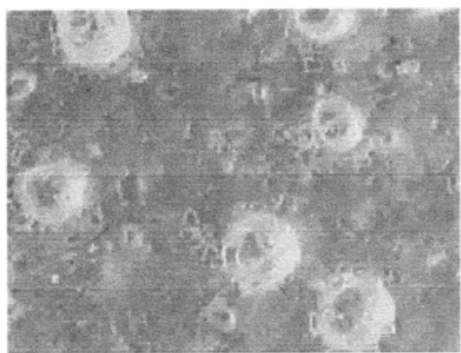

(B )

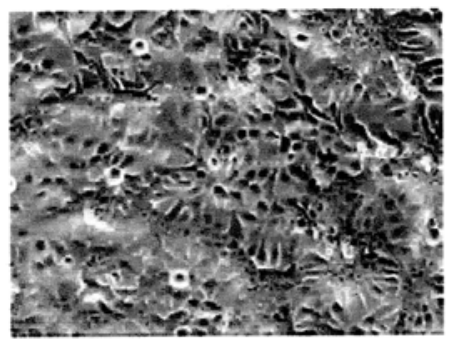

(D)

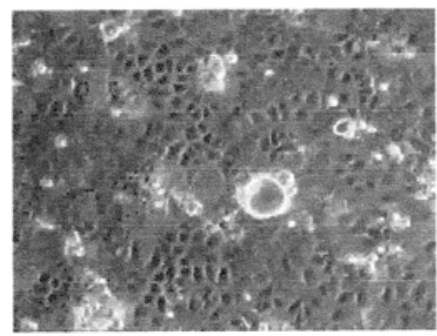

(F)

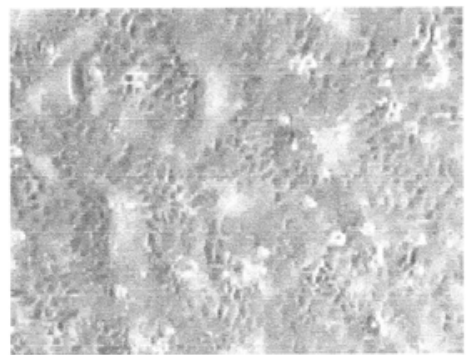


Fig. 14 Phase contrast photomicrographs of human urothelial cell line. Picture (A) and (B) represent the control UROtsa cells. (A) The UROtsa cells were cultured in cell culture medium contained $5 \%$ fetal bovine serum. Cells showed $100 \%$ confluence. (B) UROtsa cells were cultured in serum-free medium. Cells started to form three-dimensional structure.

All exposed cells were cultured with arsenic or cadmium for 9-10 weeks. (C) UROtsa cells with $1 \mu \mathrm{M}$ arsenic were cultured with serum medium. Cells were $95 \%$ of confluence and showed a characteristic epithelial morphology with phase-bright in intercellular borders and numerous mitotic figures. (D) UROtsa cells with $1 \mu \mathrm{M}$ arsenic were cultured without serum. (E) UROtsa cells with $1 \mu \mathrm{M}$ cadmium were cultured with serum medium. Cells were above $100 \%$ of confluence. (F) UROtsa cells with $1 \mu \mathrm{M}$ cadmium were cultured without serum. All exposed cells showed no significantly different morphology. Magnification: $10 \mathrm{x}$ 
seven months, and untreated wild type UROtsa cells in serum medium as a control (Fig. 15). The results demonstrated that chronic exposure to arsenic or cadmium in serum medium had an increased growth rate compared with untreated cells (Table 1A). The mean doubling time of the arsenic treated UROtsa cells in serum medium was 22.04 hours compared with a doubling time of 43.13 hours in untreated UROtsa cells in serum medium. In contrast, the growth rate of arsenic or cadmium exposed UROtsa cells in serum-free medium did not show significantly difference from untreated cells. The growth rates of UROtsa cells in serum medium are greater than those of UROtsa cells in serum-free medium. There was no significant difference of growth rate between arsenic and cadmium exposed cells. Even though the growth rates of arsenic or cadmium exposed UROtsa cells with serum were changed, there was no morphological difference. To demonstrate whether or not arsenic or cadmium in medium involved increased growth rates in these exposed cells, the exposed cells were cultured without arsenic or cadmium for two weeks. Then these cells were subcultured at a 1:20 ratio and fed once every other day without arsenic or cadmium continuously. The results demonstrated that rescued cells showed no significant difference on the growth rate of the cells when compared with non-rescued cells (Table 1B). This result demonstrated that the growth rate of chronic exposure to arsenic or cadmium UROtsa cells in serum medium was not due to the presence of arsenic or cadmium in medium. It suggests that chronic exposure to arsenic or cadmium results in increased growth rate of UROtsa cells and this change is not reversible by removal of arsenic or cadmium from medium. Similar result was reported when in vitro transformed rat liver cells by arsenic were cultured without arsenic for six 


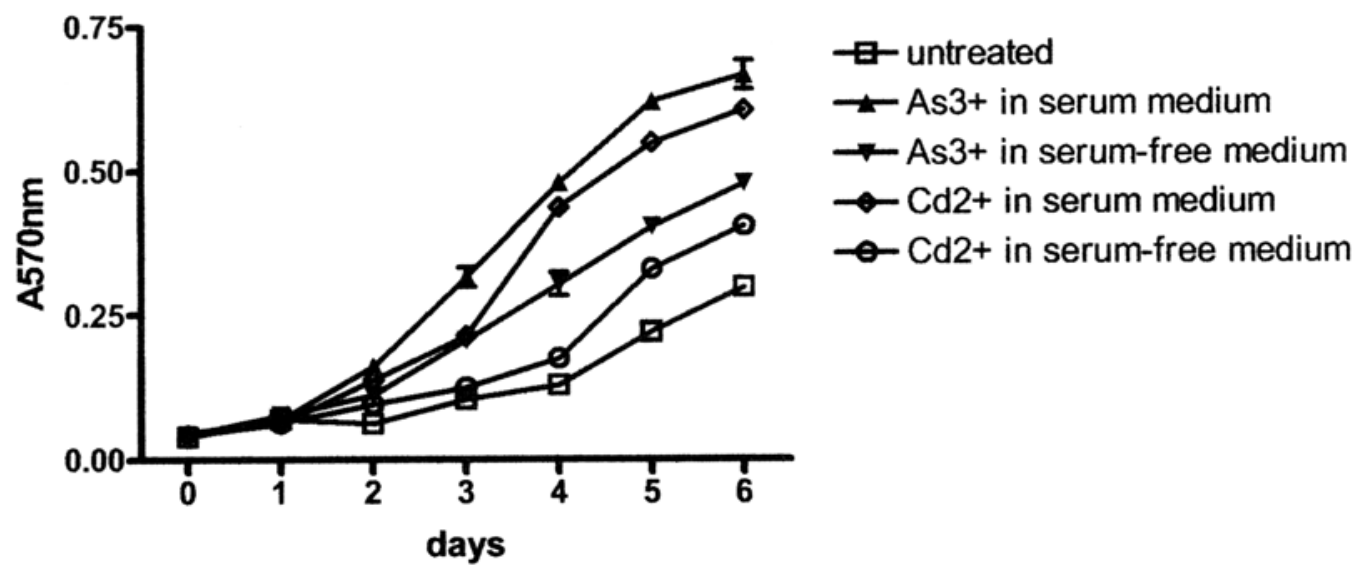

Fig. 15 The effect of cadmium or arsenic exposure on UROtsa cell growth .

Determination of growth rates of untreated UROtsa cells, UROtsa cells with $1 \mu \mathrm{M} \mathrm{CdCl}$ or $1 \mu \mathrm{M} \mathrm{NaAsO} 2$ exposed for seven months both in serum medium or serum-free medium was performed by seeding cells at a 1:20 ratio and recording absorbance at 570 $\mathrm{nm}$ at the indicated time point by MTT assay. The results presented are an average of duplicate determinations of MTT assay per plate \pm S.E. 
( A )

\begin{tabular}{|c|c|}
\hline UROtsa cells & Doubling Time ( hours ) \\
\hline $\mathrm{As}^{3+}$ with serum & 22.04 \\
\hline $\mathrm{As}^{3+} \quad$ without serum & 34.65 \\
\hline $\mathrm{Cd}^{2+}$ with serum & 26.62 \\
\hline $\mathrm{Cd}^{2+}$ without serum & 42.71 \\
\hline Untreated cells with serum & 43.13 \\
\hline
\end{tabular}

( B )

\begin{tabular}{|c|c|}
\hline Rescued UROtsa cells & Doubling Time ( hours ) \\
\hline $\mathrm{As}^{3+}$ with serum & 22.53 \\
\hline $\mathrm{As}^{3+}$ without serum & 34.69 \\
\hline $\mathrm{Cd}^{2+}$ with serum & 29.11 \\
\hline $\mathrm{Cd}^{2+}$ without serum & 41.14 \\
\hline
\end{tabular}

Table 1. Effect of exposure to arsenic or cadmium on doubling time of UROtsa cells. The three months exposed UROtsa cells were used in this experiment. The growth rate, expressed as doubling time, was calculated from the slope of linear regressed plots of LN (cell number) vs. time. By using absorbance value at $570 \mathrm{~nm}$ in Fig. 2, slope was calculated by multiplying with 100 and integrated. The integrated value was used for regression and the $\mathrm{x}$ valuable was used for slope. Table (A) represents growth rates of continuously exposed UROtsa cells. (B) After exposing for seven months, cells were rescued from arsenic or cadmium for two weeks. During growth rate measurement for one week, cells were not exposed to arsenic or cadmium. 
weeks and inoculated in the nude mice. Cells formed aggressive tumors in nude mice (10).

To test whether or not arsenic or cadmium exposure induces anchorage independent colony formation, soft agar assay was performed. Figure 16 shows the results of a typical experiment demonstrating colony formation in soft agar by UROtsa cells exposed to arsenic or cadmium. All of the unexposed UROtsa cells failed to grow in soft agar, whereas seven-month exposed cells exhibited the capacity to form colonies in soft agar (Fig. 16). To demonstrate that there was no methodological error of soft agar assay, PC-3 cells were used as positive control for all soft agar assays since several studies demonstrated colony formation of PC-3 cells in soft agar (23). The exposed UROtsa cells in serum medium formed bigger and more colonies than those in serumfree medium. The colonies were counted at a magnification of $10 \mathrm{x}$ after three weeks in soft agar (Fig. 17). The UROtsa cells in serum medium containing $1 \mu \mathrm{M}$ arsenic formed $18+/-2.57$ colonies per field, whereas cells in serum-free medium containing $1 \mu \mathrm{M}$ arsenic formed $3.17+/-0.67$ colonies per field. The UROtsa cells in serum medium with $1 \mu \mathrm{M}$ cadmium formed $10.83+/-1.96$ per field and cells in serum-free medium with 1 $\mu \mathrm{M}$ cadmium formed $0.58+/-0.16$ colonies per field. The total colony number of UROtsa cells with cadmium in serum-free was $315+/-45$ colonies per $2 \times 10^{5}$ cells. The data demonstrate that UROtsa cells in serum medium formed more colonies than in serum-free medium.

The soft agar assay assesses the ability of cells to grow in the absence of adhesion, one of the in vitro characteristics of transformation (24). The ability of arsenic or 
(A)

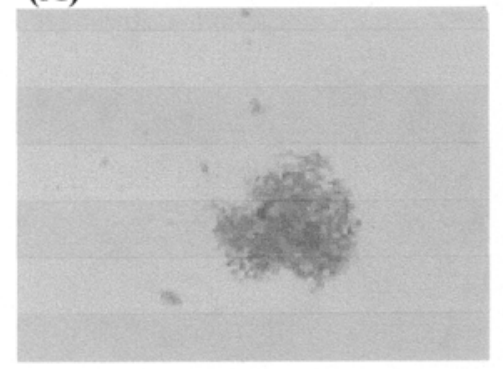

(C)

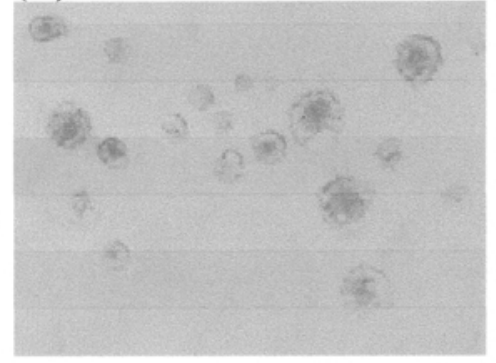

(E)

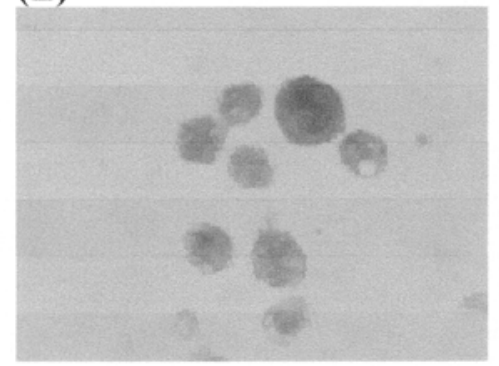

(B)

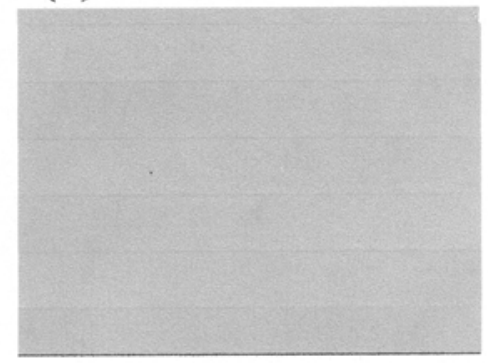

(D)

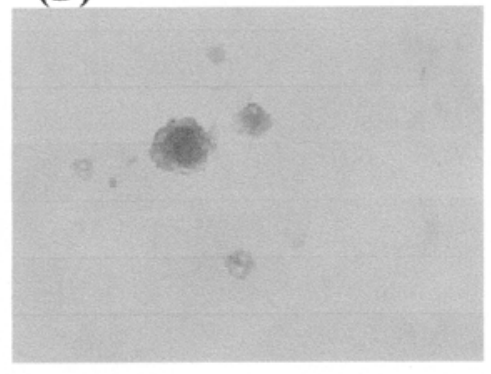

(F)

Fig. 16 Effects of arsenic or cadmium exposure to UROtsa cells in colony formation Assay. A total of $2 \times 105$ cells were plated in duplicate in $1.5 \mathrm{ml}$ of $0.275 \%$ agar in cell culture medium onto the $5 \mathrm{ml}$ of bottom layer of $0.5 \%$ agar in $6-\mathrm{cm}$ dish. The dishes were incubated at $37 \mathrm{OC}$ in a humidified $5 \% \mathrm{CO} 2$ incubator. Colonies were counted and photographed three weeks after plating. For control, PC-3 cells (A) and untreated UROtsa cells (B) were used. All treated UROtsa cells were exposed to arsenic or cadmium for seven months: (C) $1 \mu \mathrm{M}$ arsenic exposed with serum, (D) $1 \mu \mathrm{M}$ arsenic exposed without serum, (E) $1 \mu \mathrm{M}$ cadmium exposed with serum, (F) $1 \mu \mathrm{M}$ cadmium exposed without serum. Magnification: $10 \mathrm{x}$. 


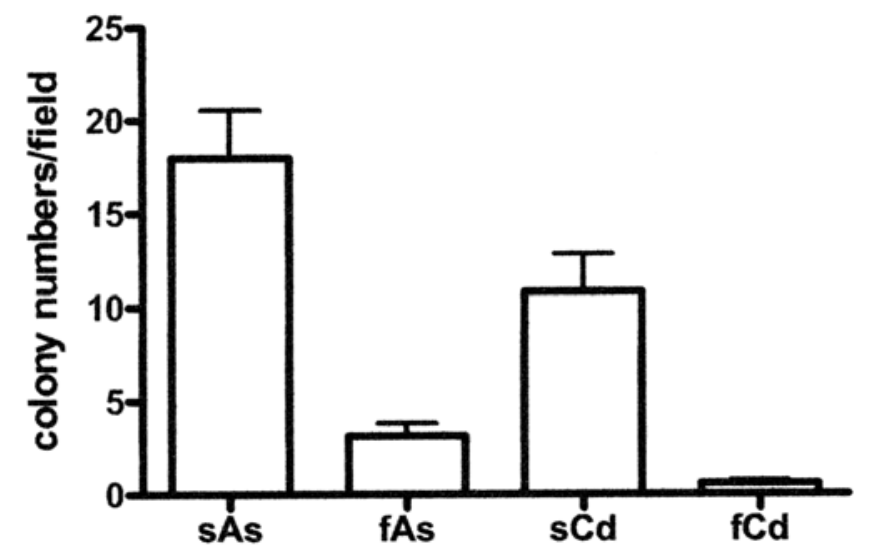

Fig. 17 Colony-formation capacity of UROtsa cells. The UROtsa cells were exposed to $1 \mu \mathrm{M}$ arsenic or $1 \mu \mathrm{M}$ cadmium for seven months. $2 \times 10^{5}$ cells per dish were incubated with $0.275 \%$ agar for three weeks at $37^{\circ} \mathrm{C}$ in $5 \% \mathrm{CO}_{2}$. The colonies of $>10$ cells were counted at $10 \mathrm{x}$ of magnification for 6 fields per dish. The sAs and sCd represent UROtsa cells in arsenic and cadmium in serum medium, respectively. The fAs and fCd represent UROtsa cells in arsenic and cadmium in serum-free medium. The results presented are an average of duplicate determinations of visible colonies per plate \pm S.E. 
cadmium exposed UROtsa cells to form colonies in soft agar suggests that they were fully transformed and may have a possibility to form tumors in nude mice.

To test the expression of metallothioneins during chronic exposure to arsenic or cadmium in UROtsa cells, levels of protein from arsenic or cadmium-seven months exposed cells were measured by immuno-dot blot. Levels of metallothionein-1 and 2 proteins increased dramatically compared to unexposed cells, $1.56+/-0.01 \mathrm{ng} / \mu \mathrm{g}$ of total protein (Fig. 18A). The MT-1 and 2 proteins in cadmium exposed UROtsa cells with or without serum showed $17.65+/-0.4 \mathrm{ng} / \mu \mathrm{g}$ and $16.23+/-0.95 \mathrm{ng} / \mu \mathrm{g}$, respectively. The MT-1 and 2 proteins in arsenic exposed UROtsa cells with or without serum showed 2.9 $+/-0.36 \mathrm{ng} / \mu \mathrm{g}$ and $9.38+/-0.47 \mathrm{ng} / \mu \mathrm{g}$, respectively. There was no significant difference in induction levels of MT-1 and MT-2 with or without serum in cell culture medium. The levels of metallothionein-3 protein in all exposed UROtsa cells were between 0.13 and $0.24 \mathrm{ng} / \mu \mathrm{g}$ (Fig. 18B). These levels were considered as undetectable levels of protein due to nonsepecific binding of immuno-dot blot systems.

\section{Discussion}

The transformation of normal cells into cancer cells requires series of distinct steps involving uncontrolled cellular proliferation, loss of intercellular adhesion, and gain of angiogenesis. Evidence indicates that tumorigenesis is a multistep process and these steps are consequences of genetic alterations that evolve progressively from normal via series of premalignant states into invasive cancers (25). Many of these phenomena have linked the extracellular matrix (ECM) to the development and control of malignancy. Cellular interactions with the ECM control cell adhesion, motility, and cellular matrix 
(A)

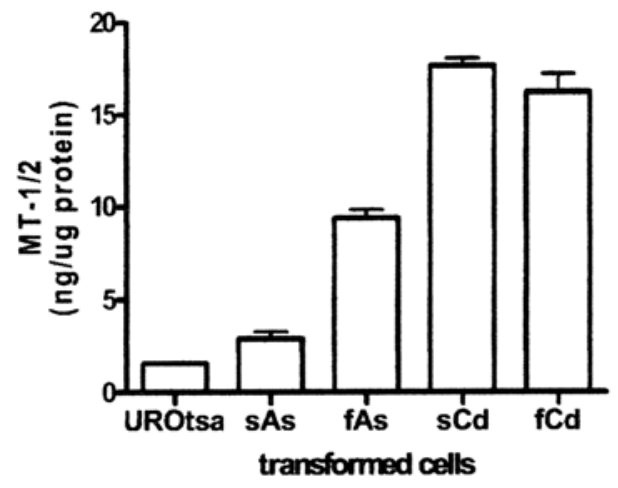

(B)

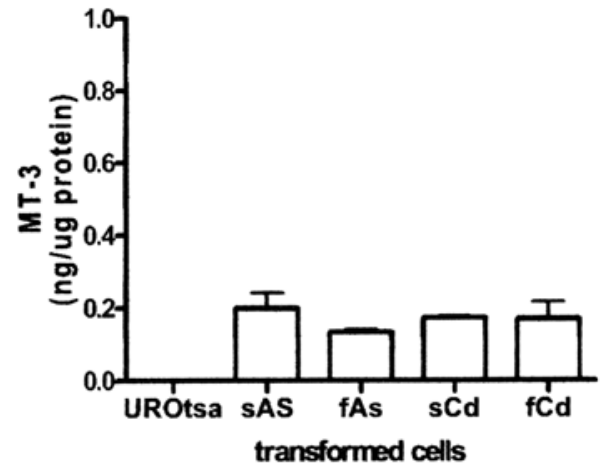

Fig. 18 Expression of metallothionein protein in UROtsa cells. The UROtas cells with $1 \mu \mathrm{M}$ arsenic or $1 \mu \mathrm{M}$ cadmium exposed for seven months and total protein was collected. Total $0.75 \mu \mathrm{g}$ and $1.5 \mu \mathrm{g}$ of protein was used for immuno-dot blot of metallothionein-1/2 and metallothionein-3, respectively. Panel (A) represents of metallothionein-1 and metallothionein-2 protein and panel (B) represents of metallothionein-3 protein. The sAs and $\mathrm{sCd}$ represent UROtsa cells in arsenic and cadmium in serum medium, respectively. The fAs and fCd represent UROtsa cells in arsenic and cadmium in serum-free medium. Levels of MT-1 and 2 proteins were determined using an immuno-dot blot with an E9 antibody. Level of MT-3 protein was determined using MT-3 specific antibody. Shown are the means and SE of triplicate cell samples. 
degradation involve malignant phenotype. The characteristics of neoplastic cells, which distinguish from their normal counterparts, may be important to understand the mechanisms of malignant transformation. Therefore, in vitro transformation model systems are very useful tools in the understanding of fundamental differences between normal cells and tumors cells if both have been derived from a common source. Although many studies have reported tumorigenesis by exposure to arsenic or cadmium, the mechanisms of arsenic- or cadmium- induced carcinogenesis are still unclear.

In this study, we showed that chronic exposure to arsenic or cadmium resulted in in vitro transformation of human uroepithelial cell line based on anchorage-independent growth. Appropriate observation on characteristic changes of UROtsa cells with arsenic or cadmium may reveal multiple steps of tumorigenesis in bladder cancer.

The first change of in vitro transformation of UROtsa cells was increased metabolic rates compared with those of unexposed cells. After exposure to arsenic or cadmium for up to 8 weeks, UROtsa cells required extra glucose for survival. The cellular metabolic rate is controlled by a number of processes including metabolic demand and substrate supply. The next two differences were increased growth rate and anchorage-independent growth. After three months exposure to arsenic or cadmium, cellular proliferation rate had increased. When growth rates of seven-month exposed cells were measured, growth rate of exposed cells with serum was twice as high as that of control cells. After exposure to arsenic or cadmium for seven months, UROtsa cells with serum formed colonies in soft agar. The growth rate of transformed UROtsa cells without serum was not changed even though these cells formed colonies in soft agar. This result 
suggests that increased growth rate may be followed by anchorage-independent growth.

The most interesting result is that there was a significant difference in the in vitro transformation of UROtsa cells depending on which cell culture system was used. There are several possibilities to explain this phenomenon. We have shown here that growth rate of cells with serum was twice as fast as that of cells without serum. In this case, even though arsenic and cadmium are not genotoxic, many studies suggest that eventually these chemicals damage to gene indirectly if transformational phenomena are irreversible. The short term exposure to low levels of these chemicals does not induce transformation. Even though it might show some morphological changes, the cells return to normal when the carcinogen is removed. The UROtsa cells with serum undergo twice as much cell division as cells without serum. Due to increased cell cycle events, cells may be more susceptible to indirect genetic damage by arsenic or cadmium and it may increase chance of aggressive malignancy. The second possibility is due to differences cell culture medium composition. The serum-free medium has very restricted nutrients and trace elements. The serum-free medium in this study contains Dulbecco's modified Eagles' medium and Ham's F-12 supplemented with selenium, insulin, transferrin, hydrocortisone, triiodothyronine and epidermal growth factor. Otherwise, serum containing medium is composed of Dulbecco's modified Eagles' medium and bovine serum. Any compound that exists in serum-free medium but not in serum containing medium may delay the onset of tumorigenesis indirectly. The third possibility is that extracellular matrix proteins or cell-cell adhesion proteins may delay transformation of UROtsa cells in serum-free medium. Under serum-free cell culture medium, confluent 
UROtsa cells produced three-dimensional structures (21). The cells displayed numerous desmosomal connections, complex interactions of the lateral membranes, and abundant intermediate filaments within the cytoplasm. Freeze fracture analysis also demonstrated that the cells possessed tight-junction sealing strands and gap junction. The overall morphology was most consistent with that found in the intermediate layers of in situ urothelium. Different expression patterns of cell adhesion proteins including integrins, âcatenin and cadherin in transformed cells have been reported (26). Reduced expression of E-cadherin has been associated with increased tumor recurrence and invasiveness and decreased overall survival of bladder patients $(27,28)$. The presence of multiple abnormalitiese in the E-cadherin-catenin complex has been correlated with advanced tumor stage in bladder cancer (29). The morphological change of cells is one of the characteristics of transformation when cells are exposed to carcinogens. Several studies have demonstrated morphological changes associated with transformed cells exposed to carcinogens or transfected by genes that are important in transformational processes (30). Several transformed cells formed morphologically different types of foci (31). In this study, we showed no morphological change in UROtsa cells after arsenic or cadmiuminduced transformation. Morphological studies have shown a correlation between loss of E-cadherin and expression and tumor cell invasion and metastasis (32). The cell adhesion proteins and several extracellular matrix proteins might be considered as tumor suppression proteins (33). It is also reported that the behavior of non-malignant bladder cells differ significantly from that of cancer ones with respect to the integrins used as well as the participation of glycosylation in adhesion (34). The integrin $\alpha 6 \beta 4$ with 
collagen VII is not lost in on the urothelium's basement membrane forming a hemidesmosomal anchoring complex, an effective barrier to cell migration. The association of integrin with collagen VII is lost in bladder cancer (35). There may be another possibility that extracelluar matrix proteins or cell-cell adhesion proteins may be involved in tumorigenesis of UROtsa cells with serum-free medium.

The metallothionein (MT) is a small protein with high binding affinity with various metals and induced by various agents. Most studies on MTs have focused on essential trace element homeostasis and heavy metal detoxification. Recently, the role of MTs in carcinogenesis has become prominent due to their linkage with drug resistance (36). Recent studies report nuclear localization of MT protein during S phase of cell cycle and malignant cells (37). Several studies have demonstrated a correlative relationship between overexpressed MT and failure of chemotherapies (38). There is ample evidence showing that overexpression of metallothionein-3 is linked to certain tumors including breast and bladder cancer $(39,40)$. The MT-3 exhibits distinct properties from MT-1 and MT-2 in several ways. Several studies have demonstrated that the expression of MT-3 (but not MT-1) inhibits the growth of cultured cells (41). MT-3, but not MT-1 or MT-2 protein also inhibits the survival of neurons cultured with brain extracts from people with Alzheimer's disease (42). The increased expression of MT-1 was not sufficient to rescue the pancreatic acinar cells from the lethal effects of MT-3 overexpression (43). Heavy metals and other agents that can induce MT-1 and MT-2 protein do not induce MT-3. Selection of tissue cells for resistance to heavy metals results in elevated levels of MT1/2 protein by amplification of the entire MT gene locus (44). This study supports that 
MT-1 and MT-2 proteins were induced dramatically by exposure to arsenic or cadmium but not MT-3 protein. This study also suggests that the increased MT-1 and 2 proteins may be not involved in the initiation of transformational steps because there was no significant difference in induction levels of MT by cadmium between serum and serumfree medium. This result supports other studies that levels of MT protein are usually undetectable in low grade tumors and increased with several high-grade in tumors $(45,46)$.

Bladder cancer is one of the few tumors in which occupational and environmental exposure is considered to be a major risk factor. This study reports in vitro transformation of nontumorigenic human urothelial cell line UROtsa by chronic exposure to low concentrations of arsenic and cadmium. The arsenic- or cadmium-transformed cells exhibited anchorage-independent growth. There was no significant difference in tumorigenic ability or other characteristics between arsenic and cadmium-induced transformation. However, there was a significant difference in tumorigenicity between cells in serum and serum-free medium. Due to the three-dimensional structure of UROtsa cell line under serum-free medium, this in vitro transformation model system will be useful not only in investigations on the mechanisms of arsenic- or cadmium- induced carcinogenesis of bladder cancer but also to study possible roles of extracellular matrix proteins and cell-cell adhesion on the progress of bladder tumor.

\section{References}

1. Waales M.P. (2000) Cadmium carcinogenesis in review. J. Inorganic. Biochem. $79: 241-244$ 
2. Fang M.Z., Mar W.C., Cho M.H. (2001) Cadmium-induced alterations of connexin expression in the promotion stage of in vitro two-stage transformation. Toxicology. 161:117-127

3. Pearson C.A., Prozialeck W.C. (2001) E-cadherin, â-catenin and cadmium carcinogenesis. Medical Hypotheses 56:573-581

4. Fang M.Z., Mar W.C., Cho M.H. (2001) Cadmium-induced alterations of connexin expression in the promotion stage of in vitro two-stage transformation. Toxicol. 161:117-127

5. Joseph P., Muchnok T.K., Klishis M.L., Roberts J.R., Antonini J.M., Whong W.Z., Ong T. (2001) Cadmium-induced cell transformation and tumorigenesis are associated with transcriptional activation of c-fos, c-jun, and c-myc protooncogenes: role of cellular calcium and reactive oxygen species. Toxicol. Science 61:295-303

6. Baudouin C., Charveron M., Tarroux R., Gall Y. (2002) Environmental pollutants and skin cancer. Cell. Biol. Toxicol. 18:341-348

7. Basu A., Mahata J., Roy A.K., Sarkar JN., Poddar G., Nandy A.K., Sarkar P.K., Dutta P.K., Banerjee A., Das M., Ray K., Roychaudhury S., Natarajan A.T., Nilsson R., Giri A.K. (2002) Enhanced frequency of micronuclei in individuals exposed to arsenic through drinking water in West Bengal, India. Mutation Res. $516: 29-40$

8. International Agency for Research on Cancer (1987) IARC monograph on the evaluation of carcinogenic risks to humans overall evaluations of carcinogenicity: 
an update of IARC monographs 1 to 42, suppl.7:100-106

9. Zhao C.Q., Young M.R., Diwan B.A., Coogan T.P, Waalkes M.P. (1997)

Association of arsenic-induced malignant transformation with DNA

hypomethylation and aberrant gene expression. PNAS 94:10907-10912

10. Goering P.L., Aposhian H.V., Mass M.J., Cebrian M., Beck B.D., Waalkers M.P. (1999). The enigma of arsenic carcinogenesis: role of metabolism. Toxicol Sci. 49:5-14

11. Moore L.E., Smith A.H., Eng C., Kalman D., De Vries S., Bhargava V., Chew K., Moor D.Jr., Ferreccio C., Rey O.A., Waldman F.M. (2002). Arsenic-related chromosomal alteration in bladder cancer. J Natl. Cancer Inst. 94:1688-1696

12. Degos L. (2003) The history of acute promyelocytic leukaemia. Br J Haematol. $122: 539-553$

13. Dong Z. (2002) The molecular mechanisms of arsenic-induced cell transformation and apoptosis. Environ Health Perspec. Suppl 5:757-759

14. Simeonova P.P., Wang S., Hulderman T., Luster M.I. (2002) c-src-dependent activation of the epidermal growth factor receptor and mitogen-activated protein kinase pathway by arsenic: role in carcinogenesis. JBC. 277:2945-2950

15. Achanzar W.E., Brambila E.M., Diwan B.A., Webber M.M., Waalkes M.P. (2002) Inorganic arsenite-induced malignant transformation of human prostate epithelial cells. J Natl Cancer Inst 94:1888-1891

16. Andrew A.S., Karagas M.R., Hamilton J.W. (2003) Decrased DNA repair gene expression among individuals exposed to arsenic in United States drinking water. 
Int. J. Cancer 104:263-268

17. Mantosky G.M., Elliott E.A. (1981) Bladder cancer epidemiology. Epidemiol. Rev. 2:203-229

18. Swaminathan S., Frederickson S.M., Hatcher J.F., Reznikoff C.A., Butler M.A., Cheever K.L., Savage R.E. Jr (1996) Neoplastic transformation and DNA-binding of 4,4'-methylenebis(2-chloroaniline) in SV40-immortalized human uroepithelial cell lines. Carcinognesis 17:857-864

19. Pratt C.I., Kao C., Wu S., Gilchrist K.W., Oyasu R., Reznikoff C.A. (1992) Neoplastic progression by EJ/ras at different steps of transformation in vitro of human uroepithelial cells. Cancer Res. 52:688-695

20. Petzoldt J.L., Leigh I.M., Duffy P.G., Sexton C., Masters J.R. ( 1995) Immortalisation of human urothelial cells. Urol. Res. 23:377-380

21. Rossi M.R., Masters J.R.W., Park S., Todd J.H., Garrett S.H., Sens M.A., Somji S., Nath J., Sens D.A. (2001) The immortalized UROtsa cell line as a potential cell culture model of human urothelium. Environ. Health Perspectives 109:801808

22. Siu L.L., Banerjee D., Khurana R.J., Pan X., Pflueger R., Tannock I.F., Moore M.J. (1998) The prognostic role of p53, metallothionein, P-glycoprotein, and MIB-1 in muscle-invasive urothelial transitional cell carcinoma. Clin Cancer Res.4:559-565

23. Kirk D., Szalay M.F., Kaighn M.E. (1981) Modulation of growth of a human prostatic cancer cell line (PC-3) in agar culture by normal human lung fibroblasts. 
Cancer Res. 41:1100-1103

24. Castle V.P., Ou X., O’Rourker K., Dixit V.M. (1993) High level of thrombospondin 1 expression in two NIH 3 T3 cloned lines confers serum- and anchorage- independent growth. JBC 268:2899-2903

25. Hanahan D., Weinberg R.A. (2000) The hallmarks of cancer. Cell 100:57-70

26. Morini M., Mottolese M., Ferrari N., Ghiorzo F., Buglioni S., Mortarini R., Noonan D.M., Natali P.G., Albini A. (2000) The á3â1 integrin is associated with mammary carcinoma cell metastasis, invasion, and gelatinase B (MMP-9) activity. Int. J. Cancer 87:336-342

27. Lipponen P.K., Eskelinen M.J. (1995) Reduced expression of E-cadherin is related to invasive disease and frequent recurrence in bladder cancer. J Cancer Res Clin Oncol.121:303-308.

28. Bringuier P.P., Umbas R., Schaafsma H.E., Karthaus H.F., Debruyne F.M., Schalken J.A. (1993) Decreased E-cadherin immunoreactivity correlates with poor survival in patients with bladder tumors. Cancer Res. 53:3241-3245.

29. Shimazui T., Schalken J.A., Giroldi L.A., Jansen C.F., Akaza H., Koiso K., Debruyne F.M., Bringuier P.P. (1996) Prognostic value of cadherin-associated molecules (alpha-, beta-, and gamma-catenins and p120cas) in bladder tumors. Cancer Res. 56:4154-4158.

30. Pawlak G., Helfman D.M. ( 2002) Post-transcriptional down-regulation of ROCK1/Rhd-kinase through an MEK-dependent pathway leads to cytoskeleton disruption in ras-transformed fibroblasts. Molecular Biology of the cell 13:336- 
31. Keshava N. (2000) Tumorigenicity of morphologically distinct transformed foci induced by 3-methylcholanthrene in BALB/c-3T3 cells. Mutation Res. 447:281286

32. Morita N., Uemura H., Tsumatani K., Cho M., Hirao Y., Okajima E., Konishi N., Hiasa Y. (1999) E-cadherin and á-, â- and ã- catenin expression in prostate cancers: correlation with tumor invasion. Brit J. Cancer 79:1879-1883

33. Witkowski C.M., Bowden G.T., Nagle R.B., Cress A.E. (2000) Altered surface expression and increased turnover of the alpha6beta4 integrin in an undifferentiated carcinoma. Carcinogenesis 21:325-330

34. Litynska A., Przybylo M., Pochec E., Laidler P. (2002) Adhesion properties of human bladder cell lines with extracellular matrix components: the role of integrins and glycosylation. Acta Biochim Polonica 49:643-650

35. Liebert M., Washington R., Wedemeyer G., Carey T.E., Grossman H.B. (1994) Loss of co-localization of alpha 6 beta 4 integrin and collagen VII in bladder cancer. Am J Pathol.144:787-795.

36. Kondo Y., Kuo S.M., Watkins S.C., Lazo J.S. (1995) Metallothioneon localization and cisplatin resistance in human hormone-independent prostate tumor cell lines. Cancer Res. 55:474-477

37. Schmidt C., Beyersmann D. (1999) Transient peaks in zinc and metallothionein levels during differentiation of 3T3L1 cells. Arch Biochem Biophys.364:91-98. 38. Wood D.P.Jr., Klein E., Fair W.R., Chaganti R.S. (1993) Metallothionein gene 
expression in baldder cancer exposed to cisplatin. Mod. Pathol. 6:33-35

39. Sens M.A., Somji S., Garrett S.H., Beall C.L., Sens D.A. (2001) Metallothionein isform 3 overexpression is associated with breast cancers having a poor prognosis. Am. J. Pathol. 159:21-26

40. Sens M.A., Somji S., Lamm D.L., Garrett S.H., Slovinsky F., Todd J.H, Sens D.A. (2000) Metallothionein isoform 3 as a potential biomarker for human bladder cancer. Environ Health Perspect 108:413-418

41. Palmiter R.D. (1995) Constitutive expression of metallothionein-III (MT-III), but not MT-I inhibits growth when cells become zinc deficient. Toxicol.

Appl.Pharmacol. 135:139-146

42. Uchida Y., Takio K., Ihara Y., Tomonaga M. (1991) The growth inhibitory factor that is deficient in Alzheimer's disease brain in a 68 amino acid metallothioneinlike protein. Neuron 7:337-347

43. Quaife C.J., Kelly E.J., Masters B.A., Brinster R.L., Palmiter R.D. (1998) Ectopic expression of metallothionein-III causes pancreatic acinar cell necrosis in transgenic mice. Toxicol and appl Pharmacol. 148:148-157

44. Durnam D.M., Palmiter R.D. (1987) Analysis of the detoxification of heavy metal ions by mouse metallothioneins. Experinita 52:457-463

45. Saga Y., Hashimoto H., Yachiku S., Tokumitsu M., Kaneko S. ( 2002) Immunohistochemcal expression of metallothionein in human bladder cancer: correlation with histopathological parameters and patient survival. J. Urol. $168: 2227-2231$ 
46. Brown J.J., Xu H., Nishitani J., Mohammed H., Osborne R., Teklehaimanot S., Gill G., Liu X. (2003) Potential biomarkers for head and neck squamous cell carcinoma. Laryngoscope 113:393-400 
Tumorigenicity and Histological Observation of Tumors Produced by Arsenic- or Cadmium-Transformed Cells in Nude Mouse 


\section{Introduction}

Human urinary bladder cancer is the fourth most common form of cancer among men and eighth among women (1). Bladder cancer is one of tumors in which occupational and environmental exposure to chemicals have been documented as major risk factors. Carcinogens derived from occupational exposures, cigarette smoking, recurrent inflammatory conditions and schistosomal infections are important factors for initiation of bladder cancer (2). Although most bladder cancers initially were diagnosed as superficial papillary transitional cell carcinomas with relatively benign condition, $15 \%$ of diagnosed patients went through progression to deep muscle invasion of superficial bladder tumor due to high recurrent rates (3).

Based on epidemiological and animal studies, arsenic and cadmium are considered as human carcinogens, although the molecular mechanisms are still unclear $(4,5)$. The development of model system for in vitro transformation of human bladder cell line by exposure to arsenic or cadmium is important to understand molecular mechanisms of bladder tumors by these carcinogens. Urothelium is a highly specialized tissue lining the mammalian urinary tract, and is described as a transitional epithelium. Ninty percent of bladder cancer is due to malignant transformation of these transitional epithelial cells. In the previous study, we showed chronic exposure of low concentration of arsenic or cadmium resulted in malignant transformation of human urothelial cell line, UROtsa, based on increased growth rate and anchorage-independent growth in soft agar. In the present study, we examined the tumorigenicity of these transformed UROtsa cells.

\section{Tumorigenicity Assay}


UROtsa cells exposed for seven months to $1 \mu \mathrm{M}$ arsenic or $1 \mu \mathrm{M}$ cadmium UROtsa cells with and without serum were used to test capability of tumor development after injection into nude mouse. Figure 19 demonstrates the results of a representative experiment with $\mathrm{NCr}-\mathrm{nu} / \mathrm{nu}$ mice and the efficiency of tumor formation calculated from all of the experiments. The untreated UROtsa cells and PC-3 cells were used for negative and positive controls, respectively. Tumors arose in 10 out of 11 mice injected PC-3 cells while none of the untreated UROtsa cells gave rise to tumors in any mouse. All transformed UROtsa cells were capable of forming tumors within 1 week after injection into the athymic nude mice. The arsenic or cadmium- transformed cells with serum formed tumors 10 out of 10 , and 10 out of 11 inoculated mice, respectively. The arsenic or cadmium- transformed cells without serum formed tumors 5 from 9 , and 7 from 10 inoculated mice, respectively. Although the frequency of colony formation of transformed cells without serum in soft agar was lower than that of transformed cells with serum, the tumor incidence in nude mice was not significantly different (Table 2).

\section{Histology of nude mouse tumors produced by cadmium-transformed cells}

Tumor tissues of nude mouse produced by transformed UROtsa cells from 5-9 weeks after injection were fixed in $10 \%$ neutral formalin and processed for paraffin embedding. There was no tumor metastasis because the border between tumors and surrounding tissues was clearly delineated. The tumors formed by the cadmium transformed UROtsa cells with serum were composed of infiltrating nests and masses of moderately differentiated cells (Fig 20A). These infiltrating tumor nests and masses demonstrated increased differentiation from the basal surface with was composed of 


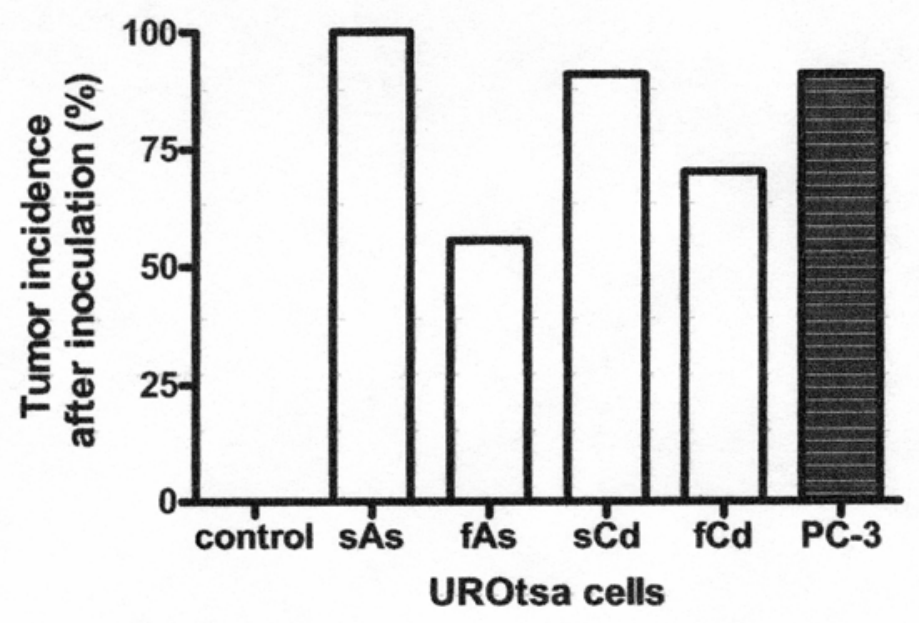

Fig. 19 Tumorigenicity of arsenic or cadmium exposed UROtsa cells in nude mice. UROtsa cells treated with $1 \mu \mathrm{M}$ arsenic or cadmium for seven months were inoculated subcutaneously into nude mice $(n=9-11)$. Tumor incidence data as a percentage of the number of mice inoculated was collected 5 weeks after injection. The sAs and sCd

represent that UROtsa cells in arsenic and cadmium in serum medium, respectively. The fAs and fCd represent that UROtsa cells in arsenic and cadmium in serum-free medium. The untreated PC-3, prostate cancer cell line, was used for positive control. 


\begin{tabular}{|c|c|c|}
\hline Injected UROtsa cells & $\begin{array}{c}\text { Tumor formation in } \\
\text { nude mice }\end{array}$ & $\begin{array}{l}\text { Colony numbers in } \\
\text { soft agar (per field) }\end{array}$ \\
\hline Untreated with serum & $0 / 10$ & 0 \\
\hline Arsenic with serum & $10 / 10 \quad(100 \%)$ & $>10$ \\
\hline Arsenic without serum (fAs) & $5 / 9 \quad(56 \%)$ & $<3$ \\
\hline Cadmium with serum & $10 / 11 \quad(91 \%)$ & $>10$ \\
\hline Cadmium without serum ( $\mathrm{fCd}$ ) & $7 / 10$ & $<1$ \\
\hline
\end{tabular}

Table 2 Tumorigenicity of arsenic or cadmium exposed UROtsa cells in nude mice. UROtsa cells treated $1 \mu \mathrm{M}$ arsenic or cadmium for seven months were inoculated subcutaneously into nude mice $(n=9-11)$. Tumor incidence data as a percentage of the number of mice inoculated was collected 5 weeks after injection. 
( A )
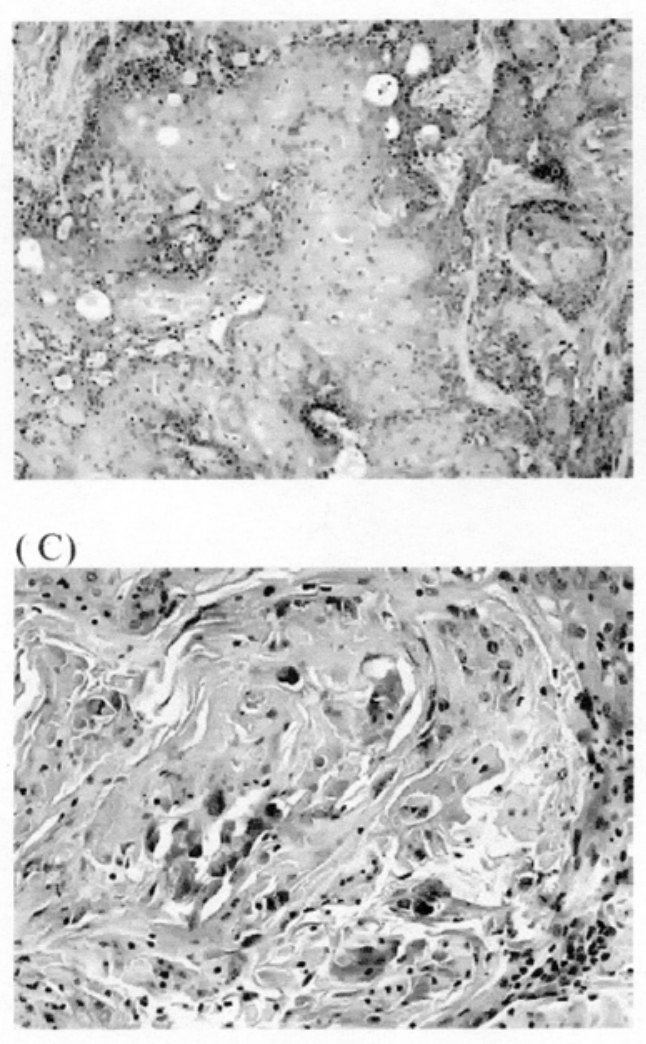

( B )

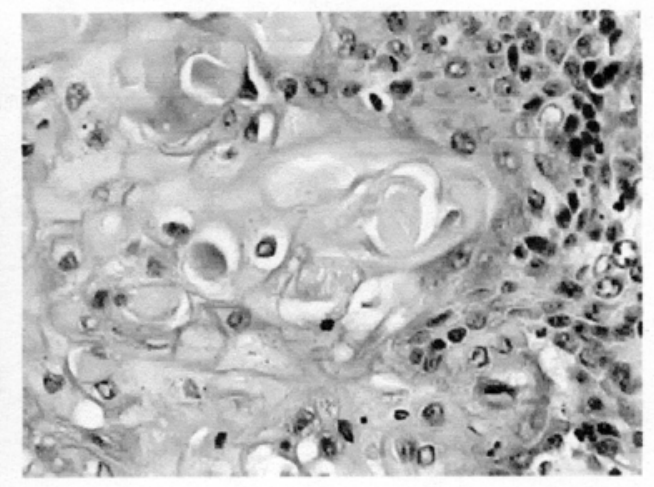

Fig 20. Histological analysis of tumors produced by heterotransplatation of cadmium-transformed UROtsa cells with serum into nude mice. General view of H \& E stained tissues from tumor derived by inoculated cadmium transformed cells.

(A) Nests and cords of infiltrating cells with centrally located, large, eosinophilic cells and focal central necrosis. The tumor sample was shown at the 7 weeks of injection with $40 \mathrm{x}$ of magnification. (B) Eosinophilic, filamentous cytoplasmic accumulation s in cells. The shown tumor tissue was taken picture at $400 \mathrm{x}$ magnification at the 7 week of stage after injection. (C) Calcium deposits in areas of central necrosis within tumor nests. The shown tumor tissue was at 200x magnification at the 9 week of stage after injection. 
small compact cells. Larger, more differentiated cells, characterized by an eosinophilic cytoplasm and a distinct cell border were present towards the center of these tumor masses (Fig 20A). These more differentiated cells were very common and most contained eosinophilic filamentous material which was often swirled within the individual cells (Fig 20B). Areas of necrosis were rare even within the largest tumor specimens, but when present often contained prominent calcification admixed with eosinophilic laminations within the central necrotic areas (Fig 20C). The tumors formed by cadmium-transformed UROtsa cells without serum formed smaller tumors in the nude mice and were composed mainly of tight nests of moderately differentiated cells (Fig 21A). The tumors formed tight nests and whorls with little tendency for differentiation towards the center of the mass and there was also very little tendency for central necrosis or deposit within cells (Fig 21A). Although cells could be found that demonstrated differentiation towards the central areas of the whorls, this was not as prominent as found for tumors by transformed cells with serum, and many areas of the tumor had minimal tendency for this phenotypic squamoid differentiation ( Fig 21B). There was a slight increase in nuclear pleomorphism as noted by vesicular nuclei, nuclear lobulations and occasional nucleoli (Fig 21B, C).

\section{Histology of nude mouse tumors produced by arsenic-transformed cells}

The tumors formed by arsenic-transformed UROtsa cells with serum were remarkable for the phenotype of squamoud differentiation. Tumor sheets and nests demonstrated large central areas of acellular, esosinophilic, concentrically laminated deposits resembling the keratin 'pearls' of squamous cell carcinoma (Fig 22A,B). The uppermost layers of neoplastic cells, just underneath the acellular deposits, contained 

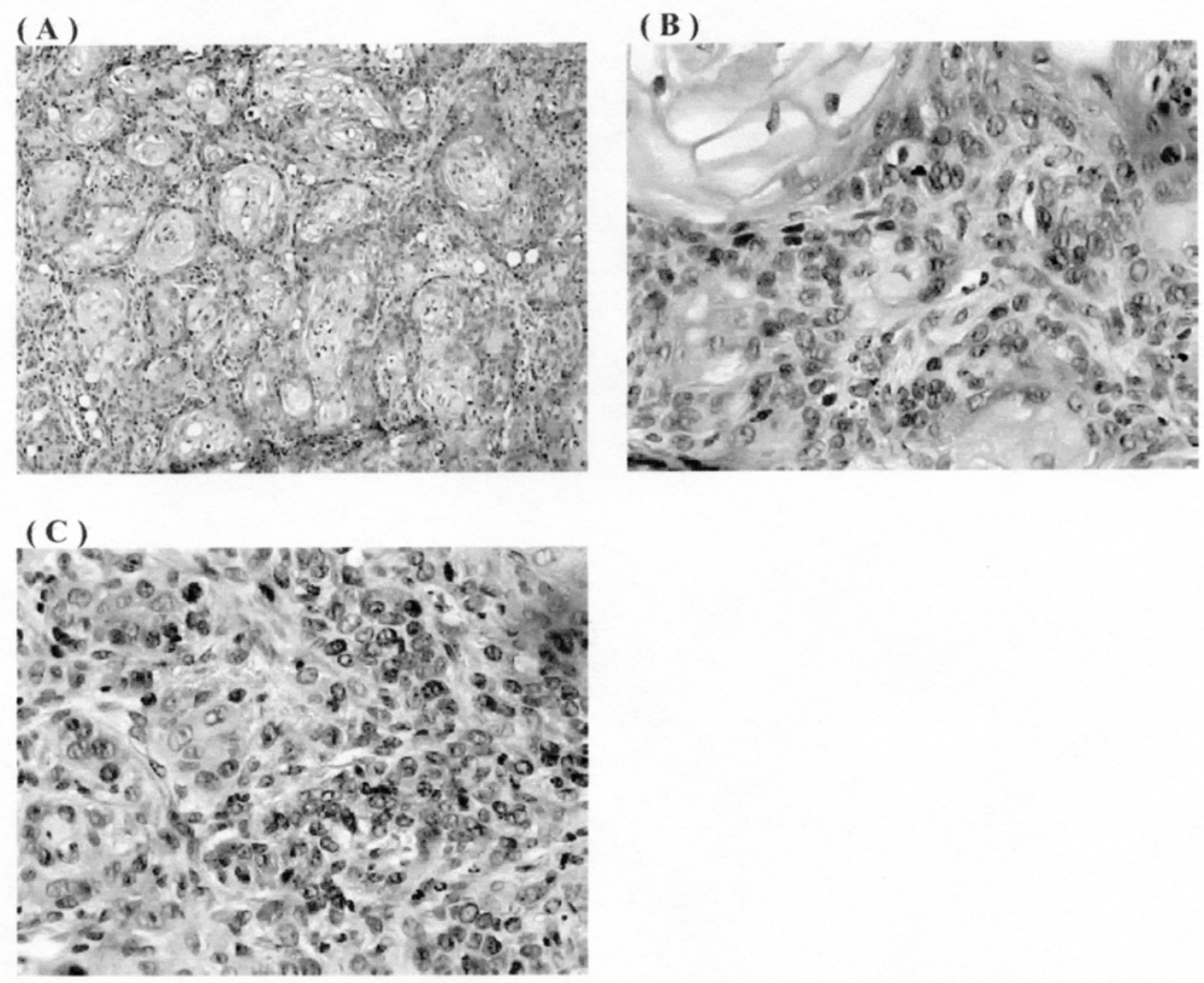

Fig 21. Histological analysis of tumors produced by heterotransplatation of cadmium-transformed UROtsa cells without serum into nude mice.

General view of $\mathrm{H} \&$ E stained tissues from tumor developed by cadmium-transformed UROtsa cells cultured in serum-free medium.

(A) Small compact nests of cells lacking the central necrosis were shown at 100x magnification of 6week stage of injection. (B) A rare focal showing squamoid phenotypic change at 400x magnification of 6 week of stage after injection. (C) Mild to moderated nuclear pleomorphism was shown at $400 \mathrm{x}$ magnification at the 6 week after injection. 
(A)

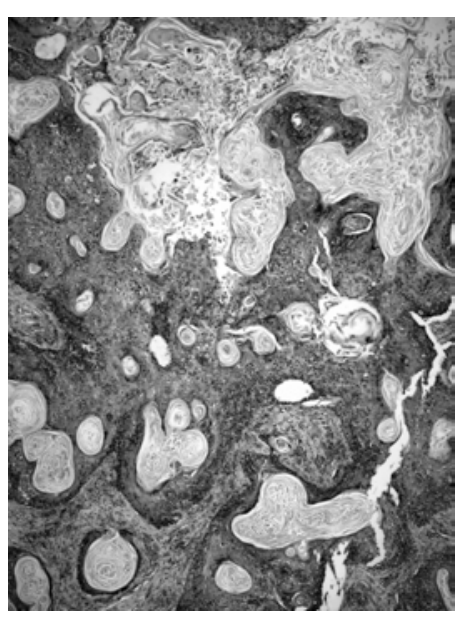

(B)

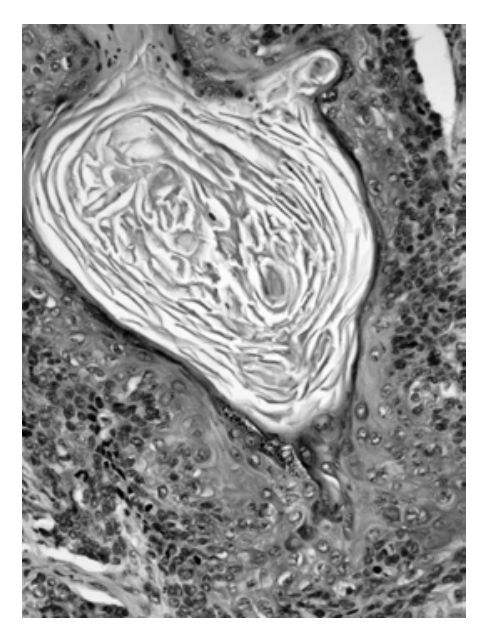

(C)

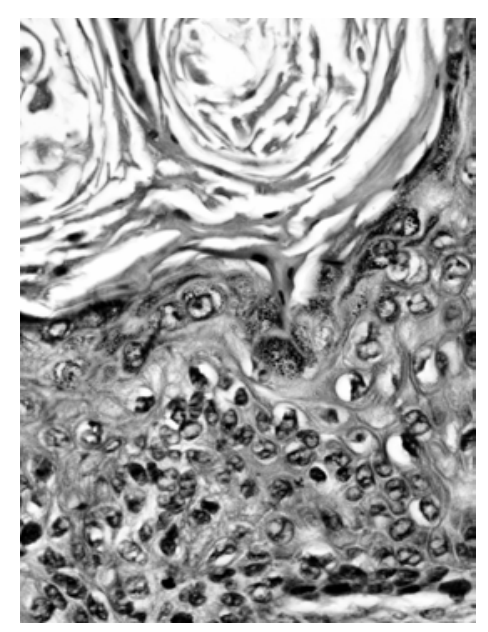

(D)

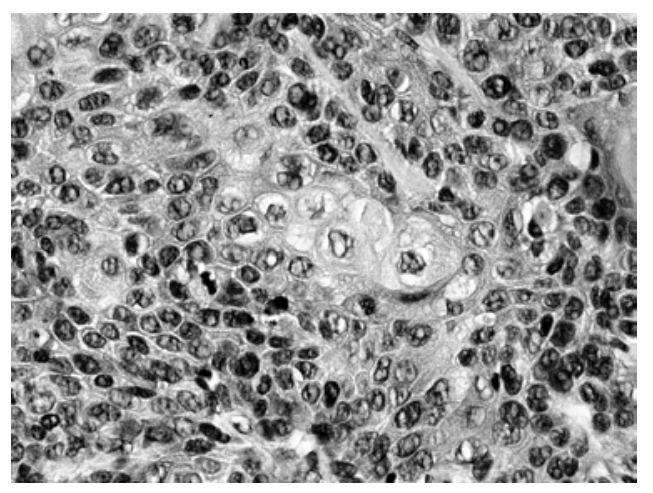

(E)

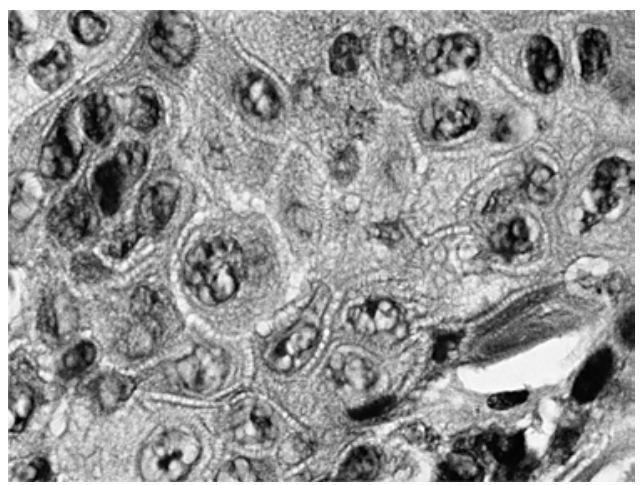


Fig 22. Histology (H\&E staining) of tumors produced by heterotransplantation of arsenic-transformed UROtsa cells with serum into nude mice. (A) Typical area of a tumor heterotransplant showing large squamous change $(25 \mathrm{x})$ at the 9 week stage of injection. ( B) Squamous features with a central "pearl" of acellular, concentric deposits $(200 \mathrm{x})$ at the 9 week of stage after injection. (C) Cells recapitulating granular cell layer of squamous epithelial with basophilic keratohyaline and a centrally located laminated "pearl" $(400 \mathrm{x}), 9$ week stage. (D) Cells with intracellular bridges recapitulating the "spiny" layer in squamous epithelium (400 x), 5 week stage. (E) Intracellular bridging between cells $(800 \mathrm{x}), 5$ week stage. 
punctuate basophilic granules resembling the keratohyaline seen in the granular layer of the skin epidermis (Fig 22C). Also recapitulating the squamous differentiation, neoplastic cells between this and the basal layer of cells demonstrated prominent intracellular connections (Fig 22D, E), similar to the granulose or spinous cells within the skin. The tumor cells displayed moderate nuclear pleomorphism with irregular nuclear contours, grooves, and chromatin distribution with occasional prominent nucleoli. The morphology of the tumors formed by arsenic-transformed UROtsa cells without serum was similar to those grown on serum-containing growth medium (Fig 23A). These tumors exhibited more pleomorphism although the squamous features could still be easily discerned (Fig 23A). Nuclear features were more pleomorphic with prominent nucleoli and occasional multinuclear giant cells (Fig 23B).

Histology of nude mouse tumors produced by human prostate cancers was examined. Tumors from nude mice with inoculation of human prostate cancer cell line, PC-3, showed less differentiated condition. Tumors were composed of sheets of undifferentiated cells without whorls or nests of squamous or transitional cell differentiation (Fig 24A, B). No intracellular bridges, acellular deposits or spinous processes were observed. There was moderate pleomorphism in both the cells and nuclei. Foci of necrosis were scattered throughout the cellular sheet.

\section{Discussion}

There is extensive epidemiologic evidence that trivalent and pentavalent forms of arsenic cause characteristic skin alterations, including hyperkeratosis and skin cancer in humans (6). Epidemiologic studies have shown a strong association between arsenic 

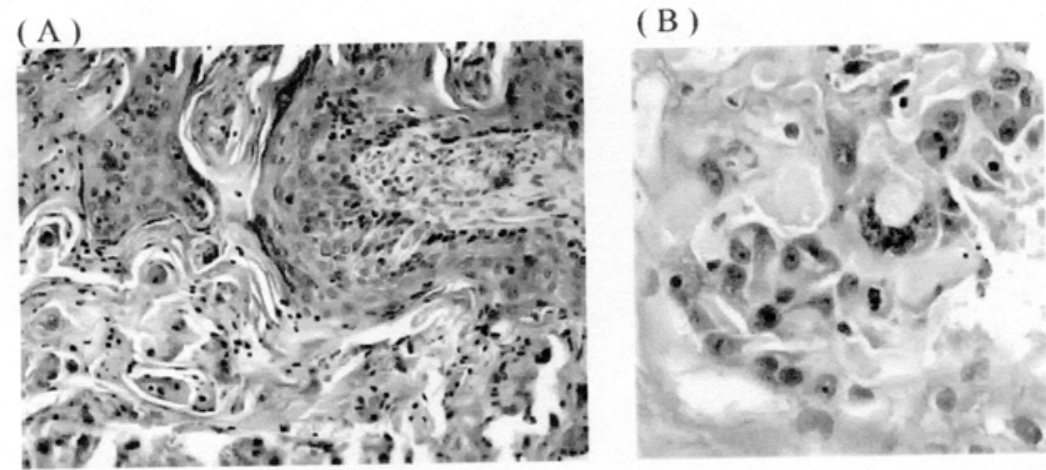

Fig 23. Histology of tumors produced by heterotransplantation of arsenictransformed UROtsa cells without serum into nude mice. Histological results from 9 week- tumor tissues after $\mathrm{H} \& \mathrm{E}$ stain. (A) Squamous changes in poorly formed whorls at $200 \mathrm{x}$ magnifications. (B) Nuclear pleomorphism and tumor giant cells at $630 \mathrm{x}$ magnifications.
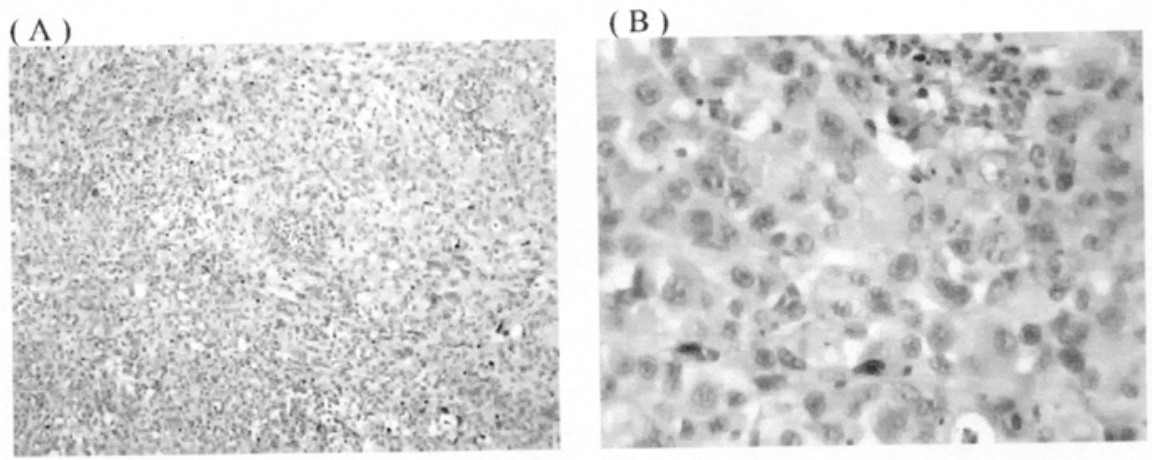

Fig 24. Histology of tumors produced by human prostate cells injected nude mice. The human prostate cells, PC-3, were injected into nude mice. After 5 weeks later, mice were sacrificed and tumor tissues were removed, fixed in neutral formalin, embedded in paraffin, sectioned at $5 \mu \mathrm{m}$, and stained with $\mathrm{H} \& \mathrm{E}$ stain. (A) and (B) showed that tumors were composed of undifferentiated cells without whorls or nests of squamous or transitional cell differentiation. 
ingestion from contaminated drinking water and the development of bladder cancers in Taiwan, Argentina, Chile, and Japan (7-10). Combined in vitro transformation and nude mouse tumorigenicity studies will be helpful in understanding the carcinogenic potential of environmentally and occupationally related agents (11).

In this study, we showed tumorigenicity of arsenic or cadmium-transformed human urothelial cell line. Tumorigenic animal cells injected subcutaneously into nude mice produce well-defined and frequently encapsulated tumors at the site of injection. Examination of histological sections of tumors that develop after the injection of tumorigenic animal cells into nude mice confirms the well-circumscribed nature of the growing tumor. In addition, tumors that develop in nude mice after transplantation of malignant tumor cells retain the original tumor histopathology in the nude host. Tumors that grew in the nude mouse after heterotransplantation of human adenocarcinomas still resembled the original adenocarcinomas histologically (12). A unique finding in the present study was the morphology of the tumors produced by the heterotransplantation of the arsenic-transformed UROtsa cells into nude mouse. In the general population, the overwhelming majority of bladder cancers are transitional cell carcinomas with little or no evidence of squamous differentiation. In contrast, the tumor heterotransplants formed by the arsenic-transformed UROtsa cells displayed dominant features of squamous differentiation. These features include: concentrically laminated deposits resembling keratin "pearls"; granules resembling the keratohyaline seen in the granular layer of the skin epidermis; and, cells with predominant intracellular connections similar to the granulosa or spinous cells within the skin. It is possible that the squamous differentiation 
may be an artifact of the model system or it may be a real feature to be expected in bladder cancers that arise from urothelial cells experiencing a long-term, substantial exposure to arsenic. The best answer to this question would be a study detailing the type of bladder cancers produced by patients in areas where there are high concentrations of arsenic in the drinking water. There is indirect evidence to suggest that the feature of squamous differentiation is a legitimate property of the urothelium transformed by longterm exposure to arsenic. The most compelling evidence is that a hallmark of high level environmental arsenic exposure is hyperkeratosis and skin cancer $(13,14)$. Therefore, it would not be surprising if the keratinocyte-like cells of the bladder reacted to arsenic similar to that found for skin keratocytes. Specificity for arsenic is also suggested by the finding that malignant transformation of the UROtsa cells with cadmium resulted in tumor heterotransplants with minimal evidence of squamous differentiation. If the squamous differentiation was an artifact, it would be expected that a similar treatment protocol with cadmium would have produced similar results regarding squamous differentiation of the heterotransplants; however, only very rare profiles of squamous change were detected in the cadmium-induced tumors. That the squamous differentiation was not a rare one-time event is suggested by the finding that arsenic-exposed UROtsa cells grown on serum-containing and serum-free media both produced tumors with squamous differentiation when heterotransplanted into nude mice. These results suggest that bladder tumors diagnosed in areas where there exist high concentrations of arsenic in the drinking water should be examined carefully for features of squamous differentiation. There is only one other study of successful malignant transformation of human 
epithelial cells with arsenic in immortalized epithelial cell culture, RWPE-1, derived from the prostate gland (15). The RWPE-1 cells were malignantly transformed when exposed to $5 \mu \mathrm{M}$ sodium arsenite for 29 weeks. The resulting cultures formed epithelial tumors when heterotransplanted into nude mice. These tumors were positive for the production of prostate specific antigen, but displayed neither features of squamous differentiation nor keratinocyte differentiation. There were several interesting differences between the studies in the RWPE-1 and UROtsa cells. The RWPE-1 cells were exposed to $5 \mu \mathrm{M}$ arsenite for 29 weeks, a concentration which causes no noticeable cell mortality. The malignantly transformed cells were identified by the formation of foci of cells that had lost contact inhibition of growth. When these cells were heterotransplanted into nude mice, invasive tumors formed as noted by invasion of the underlying muscle layers. In contrast, the UROtsa cells experienced over $95 \%$ cell death when treated with 5 -fold less concentration of arsenic, and the malignantly transformed cells arose from clones that survived this initial arsenic-induced toxicity. Cultures arising from these clones had highly elevated growth rates but did not form foci of cells indicative of a loss of contact inhibition in cell culture medium even though they showed anchorage-independent growth in soft agar. When these cells were heterotransplanted into nude mice, tumors formed but did not invade the underlying muscles layer of the mouse. Thus, the UROtsa cells were more sensitive to arsenic toxicity than the RWPE-1cells, but the malignantly transformed RWPE-1 cells formed a more aggressive tumor.

The present study also demonstrates the cadmium-induced malignant transformation of human urothelial cells. This is a significant finding since cadmium is 
classified as a human carcinogen with the potential for implication as a bladder carcinogen; although the data is less extensive than that linking arsenic as a bladder carcinogen $(16,17)$. The present malignant transformation of human urothelial cells by cadmium presents compelling evidence that cadmium has the potential of being a human bladder carcinogen. Furthermore, the model system developed should provide a valuable set of human cell lines to study the development and progression of cadmium-induced bladder cancer. The tumor heterotransplants produced by the cadmium-transformed cells were epithelial in character and had features consistant with those expected of an undifferentiated transitional cell carcinoma of the bladder. An additional significant finding is that there is evidence that the level of cadmium required to malignant transformation of urothelial cells is quite low when compared to the prostate, an organ where there is substantial evidence for a role of cadmium as a prostate carcinogen (18, 19). The concentration of cadmium in the prostate of people with no known occupational exposure to cadmium is between 11 and $28 \mu \mathrm{M}(20,21)$. The studies demonstrating the cadmium-induced malignant transformation of human prostate epithelial cells showed that $10 \mu \mathrm{M}$ of cadmium induced transformation following 8 weeks of continuous exposure to the metal (20). This level of cadmium exposure was not noted to be lethal to the cells. In comparison, the UROtsa cells were malignantly transformed at a 10-fold lower cadmium concentration and this concentration produced significant cytotoxicity to the cells. This provides indirect evidence that human bladder urothelium might be susceptible to relatively low concentration of cadmium.

Several studies demonstrate a lack of correlation between tumorigenic 
transformation and increased colony formation efficiency, or cell growth rate. The morphological alternation may not be necessary in malignant transformation (22). Some anchorage-independent cells are not tumorigenic in nude mice, but almost all of the tumorigenic cells show anchorage-independent growth in vitro. These data suggest that the acquisition of anchorage-independent proliferation in vitro is a necessary but not sufficient for tumorigenicity. Malignancy of cultured cells is demonstrated convincingly by the tumorigenicity of cells when transplanted into athymic nude mice. In this study, we have showed that in vitro transformed UROtsa cells by exposure to arsenic or cadmium formed tumors after injection into nude mice. The tumors generated in this study showed diversity, even though these were generated from arsenic- or cadmiumtransformed UROtsa cells. These data demonstrate the capability of a human epithelial cell type to give rise to different histological phenotypes during tumorigenesis.

During tumorigenesis, different genes are turned off and on, and these phenomena differ from cell types and tumor types. Therefore, these characteristic genes and proteins can be used as markers for specific cancers and many clinical trials are being performed to identify specific markers. Effort is being made to find specific markers between benign and neoplastic cells because it will make it easier to detect cancer earlier and provide better treatment for patients. Recent studies suggest several molecules as possible molecular markers for bladder cancer. There are, however, no widely accepted tumor markers that allow widespread screening for the early presence of bladder cancer or for the detection and monitoring of advanced stages of this disease (23). In this study, we showed the arsenic-induced malignant transformation of human urothelial cells. The 
finding that human urothelial cells are directly susceptible to the transforming effects of inorganic arsenite is biologically significant because the study of arsenic-induced bladder carcinogenesis has been hampered by the lack of suitable animal models, since arsenic induced tumors in rodents have been difficult to produce unless arsenic is combined with other agents. The cell lines and heterotransplants developed in the present study are also significant as a model system on which to base studies defining the molecular and genetic events associated with arsenic-induced bladder cancer. Thus, the current model system consisting of the original non-tumorigenic UROtsa parental cell line, the arsenic-induced malignant transformants, and derived tumor heterotransplants should provide a valuable system to study the development and progression of arsenic-induced bladder cancer.

In the previous study, we showed the malignant transformation of normal human urothelial cell line by chronic exposure to cadmium or arsenic in vitro. As demonstrated in this study, the malignant transformation of these cells was confirmed by the development of tumors after inoculation of these cells into nude mice. Malignant transformation of normal human urothelial cells is compelling evidence that arsenic and cadmium have the potential to be human bladder carcinogens.

\section{References}

1. Kamat A.M., Lamm D.L. (1999) Chemoprevention of urological cancer. J. Urol. 161:1748-1760.

2. Jung I., Messing E. (2000) Molecular mechanisms and pathways in bladder cancer development and progression. Cancer Control 7:325-334

3. Lutzeyer W., Rubben H., Dahm H. (1982) Prognostic parameters in superficial 
bladder cancer: an analysis of 315 cases. J. Urol. 127:250-252.

4. Cohen S.M., Shirai T., Steineck G. (2000) Epidemiology and etiology of premalignant and malignant urothelial changes. Scand. J. Urol. Nepthrol Suppl. 205: $105-115$

5. Magos L. (1991) Epidemiological and experimental aspects of metal carcinogenesis: physicochemical properties, kinetics, and the active species. Environ. Health Perspect. 95:157-189

6. Steinmaus C., Moore L., Hopenhayn-Rich C., Biggs M.L., Smith A.H. (2000) Arsenic in drinking water and bladder cancer.

7. Chiou H.Y., Hsueh Y., Liaw K.F., Hong S.F., Chiang M.H., Pu Y.S., Lin J.S., Huang C.H., Chen C.J. (1995) Incidence of internal cancers and ingested inorganic arsenic: a 7-year follow-up study in Taiwan. Cancer Res. 55:1296-1300

8. Hopenhayn-Rich C., Biggs M.L., Fuchs A., Bergoglio R., Tello E.E., Nicolli H., Smith A.H. (1996) Bladder cancer mortality associated with arsenic in drinking water in Argentina. Epidemiology 147:117-124

9. Smith A.H., Goycolea M., Haque R., Biggs M.L. (1998) Marked increase in bladder and lung cancer mortality in a region of North Chile due to arsenic in drinking water. Am. J. Epidemiol. 147:660-669

10. Tsuda T., Babazono A., Yamamoto E., Kurumatini N., Mino Y., Ogawa T., Krishi Y., Aoyama H. (1995) Ingested arsenic and internal cancer: a historical cohort study followed for 33 years. Am. J. Epidemiol. 141:198-209

11. Fogh J., Giovanella B.C. (1978) The nude mouse in experimental and clinical 
research. Academic Press.

12. Rygaard J., Povlsen C.O. (1969) Heterotransplantation of a human malignant tumour to "Nude" mice. Acta Pathol. Microbiol. Scand. 77:758-760

13. Kitchin K.T. (2001) Recent advances in arsenic carcinogenesis: modes of action, animal models sytems, and methylated arsenic metabolites. Toxicol. Appl.

Pharmacol. 172:249-261

14. Rossman T.G., Uddin A.N., Burns F.J., Bosland M.C. (2001) Arsenite is a cocarcinogen with solar ultraviolet radiation for mouse skin: an animal model for arsenic carcinogenesis. Toxicol. Appl. Pharmacol. 176:64-71

15. Achanzar W.E., Brambila E.M., Diwan B.A., Webber M.M., Waalkes M.P. (2002) Inorganic arsenite-induced malignant transformation of human prostate epithelial cells. J. Natl. Cancer Inst. 94:1888-1891

16. International Agency for Research on Cancer (1993) Beryllium, cadmium, mercury, and exposure in the grass manufacturing industry. In: International Agency for Research on Cancer Monographs on the evaluation of the carcinogenic risks to humans. vol 58. Lyon, France. IARC.

17. Siemiatycki J., Dewar R., Nadon L., Gerin M. (1994) Occupational risk factors for bladder cancer: results from a case control study in Montreal, Quebec, Canada. Am. J. Epidemiol. 140:1061-1080

18. Waalkes M.P., Rehm S., Coogan T.P., Ward J.M. (1997) Role of cadmium in the etiology of cancer of the prostate. In: Endocrine Toxicology. 2nd ed. Washington, DC. Tayler \& Francis, 227-243 
19. Goering P.L., Waalkes M.P., Klassen C.D. (1995) Toxicology of cadmium. In:Toxicology of metals:Biochemical aspects. Berlin:Springer-Verlay, 189-214

20. Achanzar W.E., Diwan B.A., Liu J., Quader S.T., Webber M.M., Waalkes M.P. (2001) Cadmium-induced malignant transformation of human prostate epithelial cells. Cancer Res. 61:455-458

21. Elinder C.F. (1985) Normal values for cadmium in human tissues, blood, and urine in different countries. In: cadmium and health:a toxicological and epidemiological appraisal. Voca Raton, FL. : CRC Press Inc, 81-102

22. Stiles C.D., Desmond W.Jr., Sato G., Saier M.H. Jr. (1975) Failure of human cells transformed by simian virus 40 to form tumors in athymic nude mice. PNAS $72: 4971-4975$

23. Sanchex-Carbayo M., Socci N.D., Charytonowicz E., Lu M., Prystowsky M., Childs G., Cordon-Cardo C. (2002) Molecular profiling of bladder cancer using c DNA microarrays: defining histogenesis and biological phenotypes. Cancer Res. 62:6973-6980 